\title{
Palladium -catalyzed synthesis of carbazole derivatives and formal total syntheses of several naturally occurring carbazole alkaloids
}

Tricia L. Scott

West Virginia University

Follow this and additional works at: https://researchrepository.wvu.edu/etd

\section{Recommended Citation}

Scott, Tricia L., "Palladium -catalyzed synthesis of carbazole derivatives and formal total syntheses of several naturally occurring carbazole alkaloids" (2001). Graduate Theses, Dissertations, and Problem Reports. 1413.

https://researchrepository.wvu.edu/etd/1413

This Dissertation is protected by copyright and/or related rights. It has been brought to you by the The Research Repository @ WVU with permission from the rights-holder(s). You are free to use this Dissertation in any way that is permitted by the copyright and related rights legislation that applies to your use. For other uses you must obtain permission from the rights-holder(s) directly, unless additional rights are indicated by a Creative Commons license in the record and/ or on the work itself. This Dissertation has been accepted for inclusion in WVU Graduate Theses, Dissertations, and Problem Reports collection by an authorized administrator of The Research Repository @ WVU.

For more information, please contact researchrepository@mail.wvu.edu. 


\title{
Palladium-Catalyzed Synthesis of \\ Carbazole Derivatives and Formal Total Syntheses of Several Naturally Occurring Carbazole Alkaloids
}

\author{
Tricia L. Scott
}

\begin{abstract}
Dissertation submitted to the Eberly College of Arts and Sciences

at West Virginia University in partial fulfillment of the requirements

for the degree of
\end{abstract}
Doctor of Philosophy
in
Chemistry

\author{
Björn C. Söderberg, Ph.D., Chair \\ Peter M. Gannett, Ph.D. \\ Paul W. Jagodzinski, Ph.D. \\ John H. Penn, Ph.D. \\ Kung K. Wang, Ph.D. \\ Department of Chemistry
}
Morgantown, West Virginia
2001

Keywords: carbazolones, carbazoles, carbazolequinones, Stille reactions, palladium-catalyzed reactions 


\section{ABSTRACT \\ Palladium-Catalyzed Synthesis of Carbazole Derivatives and the Formal Total Syntheses of Several Naturally Occurring Carbazole Alkaloids}

\section{Tricia L. Scott}

A mild and efficient route to substituted carbazolones has been developed. This novel procedure consists of two consecutive palladium-catalyzed reactions, an intermolecular Stille coupling followed by an intramolecular reductive $N$-heteroannulation. For example, 1,2dihydro-4 $(3 H)$-carbazolone was prepared in good isolated yield $(74 \%)$ by the reductive cyclization of 2-(2-nitrophenyl)-2-cyclohexen-1-one using $\mathrm{Pd}(\mathrm{dba})_{2} \quad(6 \quad \mathrm{~mol} \%), \quad 1,3-$ bis(diphenylphosphino)propane (6 mol\%), 1,10-phenanthroline monohydrate (12 mol\%), and carbon monoxide (90 psi) in DMF at $80{ }^{\circ} \mathrm{C}$. 2-(2-Nitrophenyl)-2-cyclohexen-1-one was prepared via a Stille coupling of 2-iodo-2-cyclohexen-1-one and 2-(tri-n-butylstannyl)-1nitrobenzene. Many functional groups and ring sizes were tolerated in these reactions.

This novel approach to carbazolones was successfully applied to the formal total syntheses of several naturally occurring carbazole alkaloids including murrayaquinone A, murrayafoline A, koenigine-quinone A, murrayanine, dimeric $O$-demethylmurrayafoline $\mathrm{A}$, and $(+)$-aspidospermidine. These new syntheses are generally more efficient and higher yielding compared to the previously reported syntheses of these natural products.

In addition, reductive cyclizations of 2-(2-nitrophenyl)-2-cycloalkenones using 10\% $\mathrm{Pd} / \mathrm{C}$ and $1 \mathrm{~atm}$ of hydrogen gas in methanol at ambient temperature yielded carbazole derivatives in excellent yields. For example, reduction of 2-(2-nitrophenyl)-2-cyclohexen-1-one gave 1,2,3,4tetrahydrocarbazole in $95 \%$ yield. Methyl-substitution on the cyclohexenone ring regioselectively produced methyl-substituted tetrahydrocarbazoles, however substitution on the benzene ring led to mixtures of carbazole products. 


\section{Acknowledgments}

I would like to thank my research advisor, Dr. Björn C. Söderberg, for all his guidance and encouragement. I was very fortunate to have the opportunity to work for such a supportive,

patient, and dedicated person. I would also like to thank the members of my research committee, Dr. Kung K. Wang, Dr. Paul W. Jagodzinski, Dr. Peter M. Gannett, and Dr. John H. Penn for their time and assistance. I would also like to express my gratitude to Dr. Kay M. Brummond for serving on my committee earlier in my graduate career.

I am very grateful for the support and friendship of my coworkers in the laboratory. My special thanks go to Dr. Shubhada W. Dantale for her help and advice in preparing this dissertation. I would also like to thank Nicholas M. Burke for his assistance in preparing starting materials.

I wish to thank my family for their love, never-ending support, and encouragement through all the years. I know I never could have achieved this much without them.

The financial support of the Department of Chemistry at West Virginia University and the National Institutes of Health is also gratefully acknowledged. 


\section{Table of Contents}

Title Page

Abstract

Acknowledgments

iii

Table of Contents

iv

List of Figures

vii

List of Schemes

viii

List of Tables

$\mathrm{x}$

\section{Part I}

\section{Synthesis of Carbazolones via Palladium-Catalyzed}

\section{$N$-Heteroannulations}

1. Introduction 1

1.1. Carbazolones 1

1.2. Reductive $N$-Heteroannulation Reactions 4

2. Results and Discussion $\quad 6$

3. Conclusions 19 


\section{Part II}

\section{Formal Total Syntheses of Carbazole Alkaloids}

1. Introduction

2. Results and Discussion

2.1. Formal Total Synthesis of Murrayaquinone A

2.2. Formal Synthesis of Four Carbazole Alkaloids

2.3. Formal Synthesis of Koenigine-quinone A

2.4. Formal Synthesis of (+)-Aspidospermidine

3. Conclusions

\section{Part III}

\section{Synthesis of Carbazole Derivatives via}

\section{Palladium-Catalyzed Hydrogenation Reactions}

$\begin{array}{ll}\text { 1. Introduction } & 37\end{array}$

2. Results and Discussion 39

3. Conclusions $\quad 45$

\section{Part IV}

\section{Experimental Section}

$\begin{array}{ll}\text { 1. General Procedures } & 47\end{array}$

2. Experimental Details $\quad 48$ 
$\begin{array}{ll}\text { References } & 75\end{array}$

Curriculum vitae 


\section{List of Figures}

Figure 1: Ondansetron

Figure 2: Mushroom Metabolites $\quad 5$

Figure 3: Stille Reaction Side-Products $\quad 10$

Figure 4: Carbazole Alkaloids $\quad 22$

Figure 5: Murraya koenigii Spreng 22 


\section{List of Schemes}

Scheme 1: DDQ Oxidation of a Carbazolone $\quad 2$

Scheme 2: Fischer Indole Synthesis $\quad 2$

Scheme 3: Palladium-Catalyzed Heck-Type Reaction 3

Scheme 4: Arynic Condensation of Enaminones 3

Scheme 5: Photocyclization of Azaenaminones 3

Scheme 6: Polyphosphoric Acid Cyclization $\quad 4$

Scheme 7: Indole Synthesis $\quad 4$

Scheme 8: Watanabe's Procedure for Indoles $\quad 5$

Scheme 9: Cenini's Procedure for Indoles $\quad 6$

Scheme 10: General Synthesis of Carbazolones $\quad 6$

Scheme 11: Stille Reaction Conditions $\quad 8$

Scheme 12: Synthesis of Aryl Stannane 25 10

Scheme 13: Synthesis of Stannane 24

Scheme 14: Synthesis of 2-Iodocycloalkenones 11

Scheme 15: Synthesis of 5-Methyl-2-cyclohexen-1-one 11

Scheme 16: Preparation of Bromobenzocycloheptenone $52 \quad 12$

Scheme 17: Sandmeyer Reactions 12

Scheme 18: Reductive Cyclization Conditions To Carbazolones 13

Scheme 19: Reductive Cyclization of a Bromonitrostyrene 15

Scheme 20: Palladium-Catalyzed Synthesis of an Azacarbazole 17

Scheme 21: Alternative Approach To Carbazolones $\quad 17$

Scheme 22: Ruthenium-Bound Nitrene $\quad 18$

Scheme 23: Possible Mechanism of Reductive Cyclization $\quad 19$

Scheme 24: Synthesis of Murrayafoline A and Murrayanine 23

Scheme 25: Synthesis of Murrayafoline A and Murrayaquinone A 24

Scheme 26: Synthesis of Koenigine-quinone A 25

Scheme 27: Murrayafoline A Synthesis $\quad 25$

Scheme 28: Murrayafoline A and Murrayaquinone A Synthesis 26

Scheme 29: Diels-Alder Approach to Murrayaquinone A 27

Scheme 30: Thermal Electrocyclization Reaction to Murrayaquinone A precursor 27

Scheme 31: Copper-Promoted Annulation to Murrayaquinone A 27

Scheme 32: Palladium-Catalyzed Oxidative Cyclizations 28

Scheme 33: Electrophilic Aromatic Substitution Reaction 28

Scheme 34: Synthesis of Dimeric O-demethylmurrayafoline A 29

Scheme 35: Synthesis of (+)-Aspidospermidine $\quad 29$

Scheme 36: Formal Total Synthesis of Murrayaquinone A 31

Scheme 37: Formal Synthesis of Four Carbazole Alkaloids 33

Scheme 38: Synthesis of Stannane 124

Scheme 39: Koenigine-quinone A Synthesis

Scheme 40: Synthesis of (+)-Aspidospermidine $\quad 35$

Scheme 41: Palladium-Catalyzed Hydrogenation Reaction 37

Scheme 42: $\mathrm{TiCl}_{3}$ Reductions $\quad 38$ 
Scheme 43: Common Methods To Carbazoles 38

Scheme 44: Reductive Cyclization of 2-(2-Nitrophenyl)propenal 39

Scheme 45: Synthesis of 4-Methyl-2-(2-nitrophenyl)-2-cyclohexen-1-one 40

Scheme 46: Synthesis of 3-Methyl-2-(2-nitrophenyl)-2-cyclohexen-1-one 40

Scheme 47: Hydrogenation of Carbazolone 5 43

Scheme 48: Reductive Cyclization of 39 with Reduced Amount of Palladium 44

Scheme 49: Possible Mechanism For Reductive Cyclization 45 


\section{List of Tables}

Table 1: Stille Couplings $\quad 8$

Table 2: Reductive Cyclization Reactions $\quad 14$

Table 3: Hydrogenation Reactions $\quad 42$ 


\section{Part I}

\section{Synthesis of Carbazolones via Palladium-Catalyzed $N$-Heteroannulations}

\section{Introduction}

Carbazole alkaloids have received considerable attention since their discovery in the 1960's and the realization of their pharmacological potential. ${ }^{1}$ They exhibit a wide range of biological properties ranging from antibiotic to antitumor activity. Developing new synthetic methods toward the core carbazole structure in these alkaloids is of great interest to researchers.

\subsection{Carbazolones}

Carbazolones are carbazole derivatives that are interesting synthetic targets. Many carbazolones are biologically active. The synthetic drug ondansetron ${ }^{2}$ shown in Figure 1 is a carbazolone that is a potent $5-\mathrm{HT}_{3}$ receptor antagonist used to prevent severe nausea often caused by chemotherapy and radiation treatments in cancer patients.

\section{Figure 1}

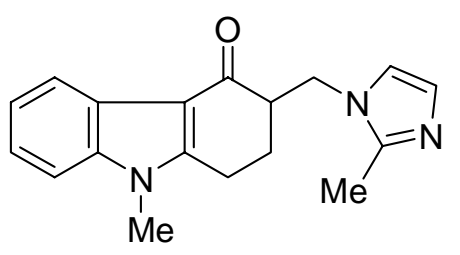

\section{Ondansetron}

Carbazolones are also of interest as synthetic precursors to naturally occurring carbazoles. A common method for preparing carbazolequinones involves the oxidation of 
carbazolones. For example, carbazolone $\mathbf{1}$ was oxidized to the carbazole alkaloid murrayaquinone-A using 2,3-dichloro-5,6-dicyanobenzoquinone (DDQ) (Scheme 1). ${ }^{3}$

\section{Scheme 1}<smiles>CC1CC(=O)c2[nH]c3ccccc3c2C1</smiles>

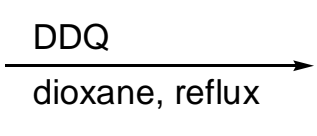<smiles>CC1=CC(=O)c2[nH]c3ccccc3c2C1=O</smiles>

A variety of methods have been utilized to obtain carbazolones. One of the most common methods used is the Fischer indole synthesis. 1,2-Dihydrocarbazol-4(3H)-one (5) was synthesized by the Fischer reaction of phenylhydrazine and 1,3-cyclohexanedione (Scheme 2). ${ }^{4}$

\section{Scheme 2}<smiles>O=C1CCCC(=O)C1</smiles>

3

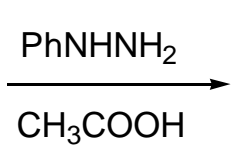

4<smiles>O=C1CCC/C(=N/Nc2ccccc2)C1</smiles>

$\stackrel{\mathrm{H}_{2} \mathrm{SO}_{4}}{\longrightarrow}$<smiles>O=C1CCCc2[nH]c3ccccc3c21</smiles>

$5(51 \%)$

Palladium-catalyzed Heck-type reactions have also been used to produce carbazolones. The intramolecular catalytic cyclization of bromo enaminones such as $\mathbf{6}$ produced carbazolones in variable yields (Scheme 3$).^{5}$ 


\section{Scheme 3}<smiles>CCN(C1=CC(=O)CCC1)c1ccccc1Br</smiles>

Carbazolones have also been synthesized by the arynic condensation of enaminones in the presence of $\mathrm{NaNH}_{2}$-tBuONa according to Scheme $4 .^{6}$

\section{Scheme 4}

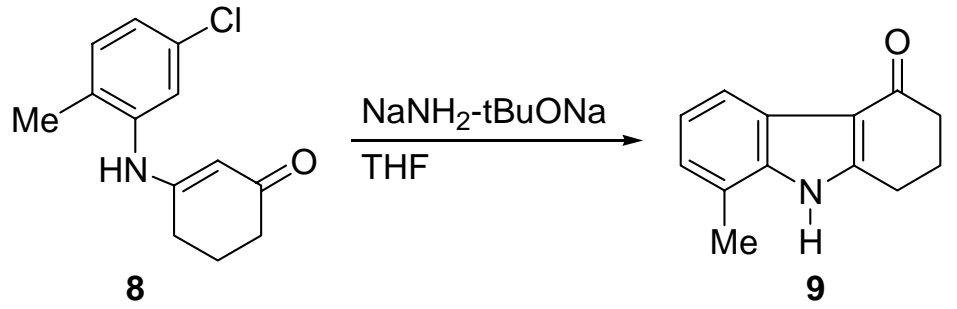

In the search for new analogs of carbazole alkaloids with modified pharmacological activity azacarbazoles have been studied. One approach to azacarbazoles involves the photocyclization of $N$-(chloropyridinyl)enaminones (Scheme 5). ${ }^{7}$

\section{Scheme 5}<smiles>O=C1C=C(Nc2cccnc2Cl)CCC1</smiles>

10<smiles>C1CC[Tl]CC1</smiles><smiles>O=C1CCCc2[nH]c3cnccc3c21</smiles>

$12(6 \%)$ 
Benzo[5,6]cyclohepta[b]indol-6-one derivatives have been prepared by the intramolecular cyclization of acids such as $\mathbf{1 3}$ using a large excess of polyphosphoric acid (Scheme 6). ${ }^{8}$ Derivatives of $\mathbf{1 4}$ are being studied for their antitumor potential.

\section{Scheme 6}

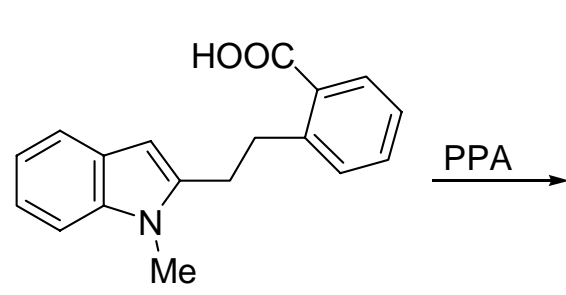

13

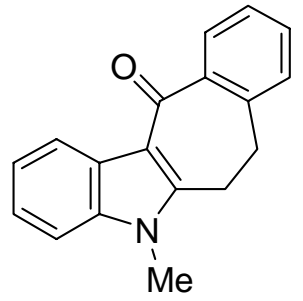

$14(62 \%)$

\subsection{Reductive $N$-Heteroannulation Reactions}

Recently, a new procedure for the synthesis of indoles was developed in our group. ${ }^{9}$ This new procedure involves the palladium-catalyzed reductive $N$-heteroannulation reaction of 2nitrostyrenes (Scheme 7). Three reagents were found to be crucial in this reaction: a palladium catalyst, a phosphine, and carbon monoxide. This reaction has proved to be useful for the synthesis of a number of indole products including several mushroom metabolites (Figure 2). ${ }^{10}$

\section{Scheme 7}

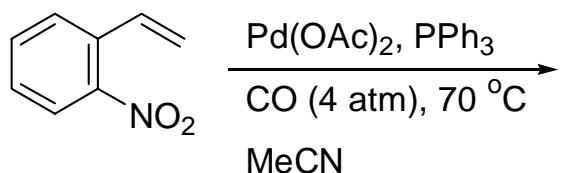

15

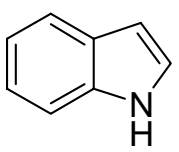

$16(87 \%)$ 


\section{Figure 2}

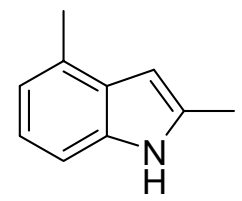<smiles>Cc1cc2c(CO)cccc2[nH]1</smiles><smiles>COCc1cccc2[nH]c(C)cc12</smiles>

\section{Mushroom Metabolites}

This type of reaction is not unknown in the literature. There are other reports of reductive carbonylations of nitroarenes with unsaturated groups in the ortho position leading to indoles. Watanabe $e t a l^{11}$ published a related procedure using a catalytic amount of $\mathrm{PdCl}_{2}(\mathrm{MeCN})_{2}$ in the presence of triphenylphosphine, excess tin dichloride, and 20 atm of carbon monoxide (Scheme 8). Another very similar reaction was reported by Cenini et al ${ }^{12}$ using $\operatorname{Pd}(\mathrm{TMB})_{2} / \mathrm{TMPhen}(\mathrm{TMBH}=$ 2,4,6-trimethylbenzoic acid; TMPhen = 3,4,7,8-tetramethyl-1,10phenanthroline) as the catalytic system (Scheme 9). Many other kinds of heterocyclic compounds can be obtained from this type of reaction including amides, amines, oximes, ureas, carbamates, and isocyanates. ${ }^{13}$

\section{Scheme 8}

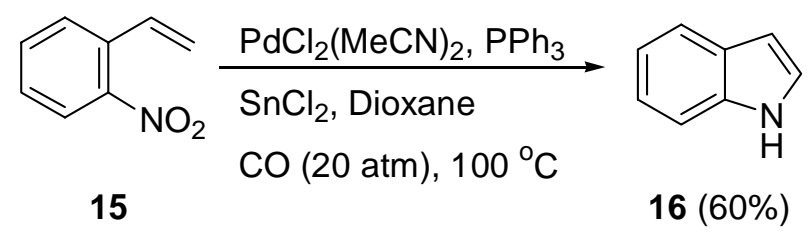




\section{Scheme 9}

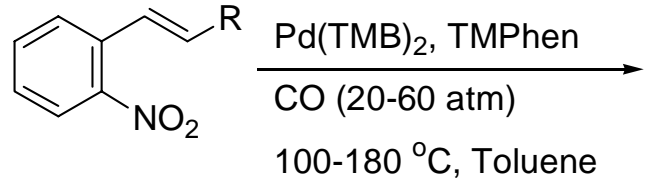

17<smiles>[R]c1cc2ccccc2[nH]1</smiles>

$18(20-95 \%)$

All these metal-catalyzed reductive cyclization reactions generally produce good yields of indoles. However, compared to the method developed in our group most of these methods employ rather harsh conditions. The reaction conditions developed in our group are much milder. Our reactions proceed at a much lower pressure of carbon monoxide, lower temperature, and do not require the addition of a Lewis acid such as tin dichloride.

Due to the inherent similarity between indoles and carbazoles, we decided to apply this new method to the synthesis of carbazole derivatives. The synthesis of several substituted carbazolones using this palladium-catalyzed reductive cyclization reaction is presented.

\section{Results and Discussion}

We envisioned that carbazolones could be prepared via the reductive cyclization of 2-(2nitrophenyl)-2-cyclohexenones as shown in Scheme 10. First, we needed to develop a method to synthesize a variety of substituted 2-(2-nitrophenyl)-2-cycloalkenones in order to test the scope and limitations of our reductive cyclization.

\section{Scheme 10}

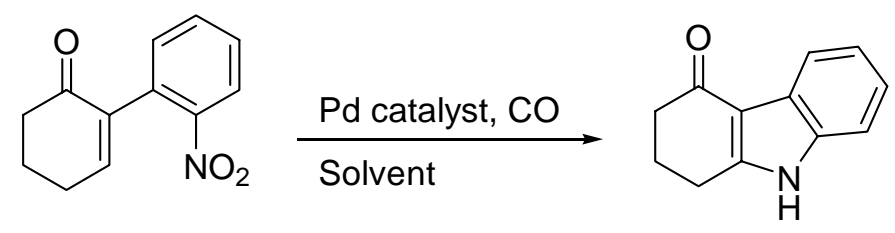


We decided to make our cyclization precursors via a Stille coupling reaction between cycloalkenones and nitrobenzenes. Johnson et $a l^{14}$ have reported the Stille couplings of 2iodocycloalkenones with aryl stannanes using $5 \mathrm{~mol} \% \mathrm{PdCl}_{2}(\mathrm{PhCN})_{2}, 10 \mathrm{~mol} \% \mathrm{Ph}_{3} \mathrm{As}$, and 10 mol\% CuI in NMP ( $N$-methylpyrrolidinone) to produce 2-phenyl-2-cyclohexenones in good yields. We adapted these conditions to our Stille reactions with good results (Scheme 11).

Table 1 shows the results of our Stille couplings to produce a variety of substituted 2-(2nitrophenyl)-2-cycloalkenones. Some modifications of the reaction conditions were required for the synthesis of compounds $\mathbf{3 7}$ and $\mathbf{4 0}$. Best yields of $\mathbf{3 7}$ were obtained when $\mathrm{Ph}_{3} \mathrm{As}$ was replaced with dppf (1,1'-bis(diphenylphosphino)ferrocene). The yield of $\mathbf{4 0}$ was improved slighty by degassing the reaction mixture. Compound $\mathbf{3 8}$ was prepared via an alternative procedure using $\mathrm{PdCl}_{2}\left(\mathrm{PPh}_{3}\right)_{2}$ in DMF.

Most of the Stille couplings proceeded in good yields. Slightly lower yields were obtained from aryl bromides as compared to aryl iodides. The lower yields of $\mathbf{3 8}$ and $\mathbf{4 0}$ are probably due to steric factors. In comparing entries 1 and 6 we see very little difference in yield resulting from reversing the polarity of substrates in the reaction. The use of an aryl stannane and vinyl iodide or a vinyl stannane and an aryl iodide both give the Stille product in good yield.

Products of the Stille reactions were easily discernable from starting materials by ${ }^{1} \mathrm{H}$

NMR. For example, the $\mathrm{C}-\mathrm{H}$ proton in iodocyclohexenone 19 shows up as a triplet at $7.76 \mathrm{ppm}$, while the same proton in coupling product $\mathbf{3 2}$ is located upfield at $6.98 \mathrm{ppm}$.

Some side-products complicating the purification of the desired compounds were identified in the Stille reactions (Figure 3). In some cases the homocoupling product $\mathbf{4 2}$ or $\mathbf{4 3}$ was present in significant amounts. Butyl group transfer also occurred in the reaction of $\mathbf{3 0}$ producing methyl 2-butyl-3-nitrobenzoate (44). Homocoupling of stannanes is a common side 
reaction in Stille couplings. ${ }^{15}$ Although the transfer of alkyl groups from the stannane is generally much slower than the transfer of aryl or vinyl groups, the transfer of alkyl groups is also sometimes observed. ${ }^{16}$

Scheme 11

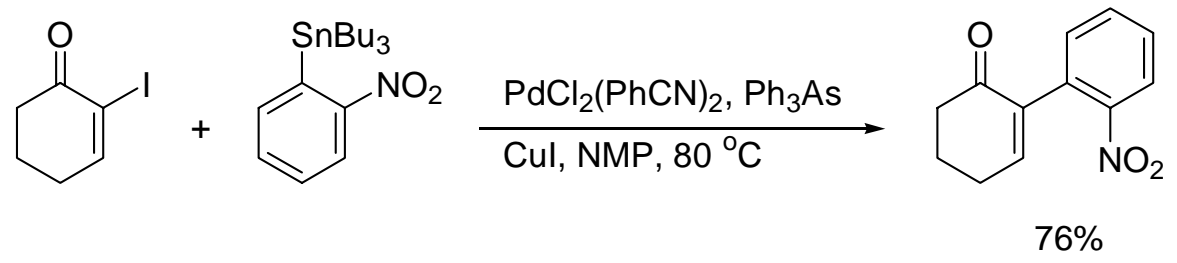

Table $1^{\mathrm{a}}$

Entry


Table 1 continued

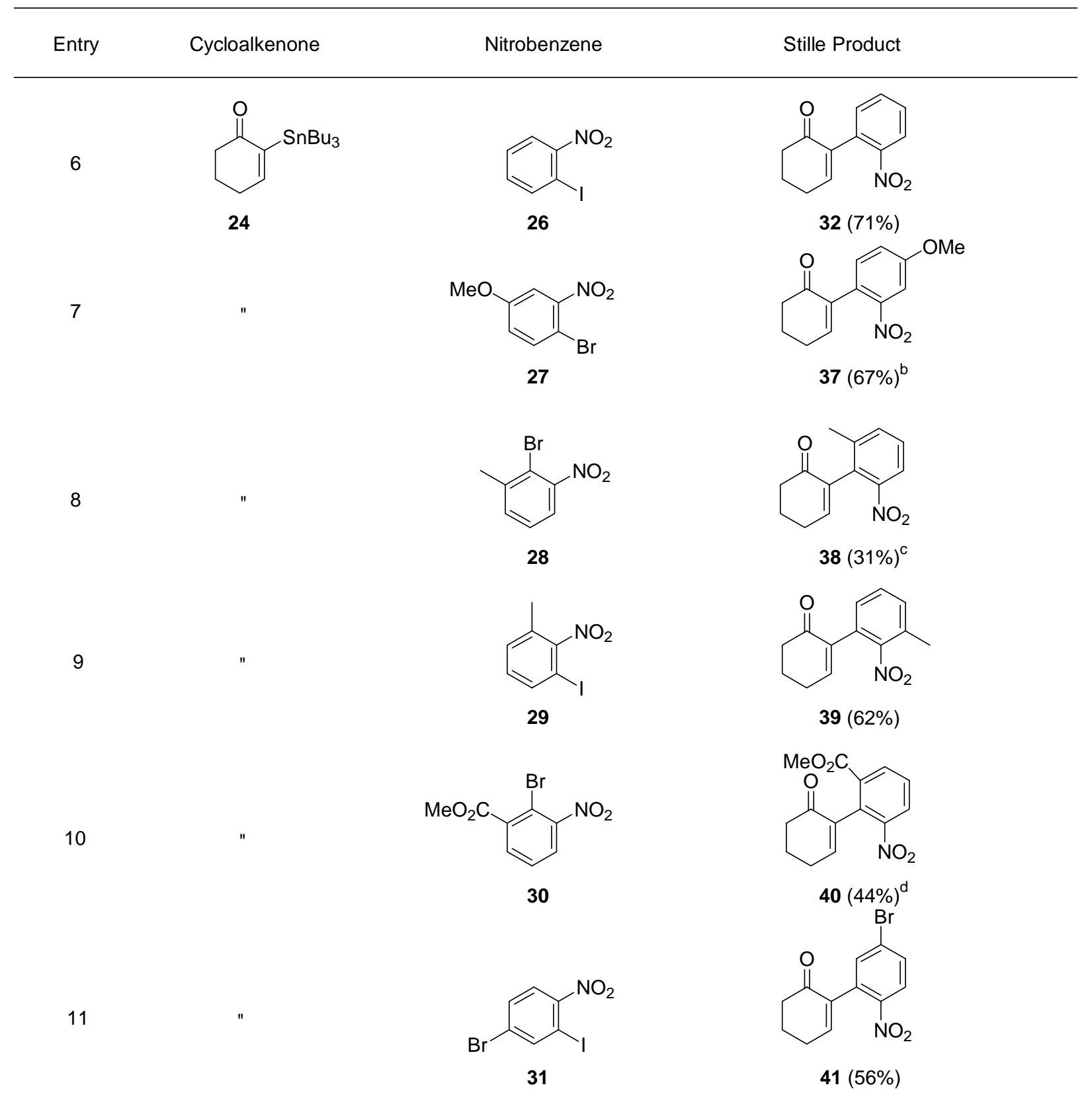

a) General conditions: 1.2 eq. Sn reagent, $5 \mathrm{~mol} \% \mathrm{PdCl}_{2}(\mathrm{PhCN})_{2}, 10 \mathrm{~mol} \% \mathrm{Ph}_{3} \mathrm{As}, 10 \mathrm{~mol} \% \mathrm{CuI}$, NMP, 80 ${ }^{\circ} \mathrm{C}$. For more exact details see: Experimental Section. b) $\mathrm{Ph}_{3}$ As was replaced with dppf. c) Conditions used: $\mathrm{PdCl}_{2}\left(\mathrm{PPh}_{3}\right)_{2}$, DMF, $110^{\circ} \mathrm{C}$. d) Reaction mixture was degassed. 


\section{Figure 3}<smiles>O=C1CCCC=C1C1=CCCCC1=O</smiles>

42<smiles>O=[N+]([O-])c1ccccc1-c1ccccc1[N+](=O)[O-]</smiles>

43<smiles>CCCCc1c(C(C)=O)cccc1[N+](=O)[O-]</smiles>

44

Two different organostannanes were prepared for the Stille reactions. Aryl stannane 25 was prepared from 1-iodo-2-nitrobenzene (26) according to Kosugi's procedure ${ }^{17}$ (Scheme 12) using hexabutylditin, in situ formed $\mathrm{Pd}\left(\mathrm{PPh}_{3}\right)_{4}$, and toluene. Vinyl stannane 24 was prepared according to Scheme 13. The metal-halogen exchange reaction of $\mathbf{4 6}$ with $t$-BuLi, followed by addition of tributyltinchloride and deprotection of the ketone with acid produced the stannane $\mathbf{2 4}$ in $83 \%$ yield.

Scheme 12<smiles>O=[N+]([O-])c1ccccc1I</smiles>

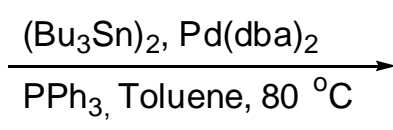

26<smiles>CCCCc1ccccc1[N+](=O)[O-]</smiles>

$25(80 \%)$

\section{Scheme 13}<smiles>O=C1C=CCCC1</smiles><smiles>O=CC(CCCCCO)C(Cl)(Br)Br</smiles>

45<smiles>BC1=CCCCC12OCCO2</smiles>

46 (89\%)
1) $t$-BuLi, Ether

3) $\mathrm{H}^{+}$<smiles>CCCCCCCCCCCCC</smiles>

24 (83\%) 
The literature procedure was followed for preparing 2-iodocycloalkenones 19 and 21, and this method was utilized for the preparation of the previously unknown compounds $\mathbf{2 0}$ and $\mathbf{2 2}$ (Scheme 14). ${ }^{18}$ Most of the cycloalkenone starting materials were commercially available. 5Methyl-2-cyclohexen-1-one (47) was prepared according to literature procedure ${ }^{19}$ (Scheme 15), although in our hands this reaction failed to produce the reported yield of $78 \%$ for this compound.

\section{Scheme 14}

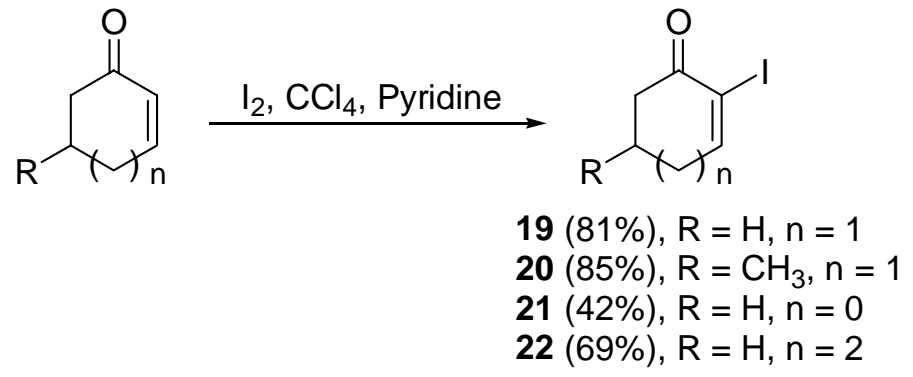

\section{Scheme 15}

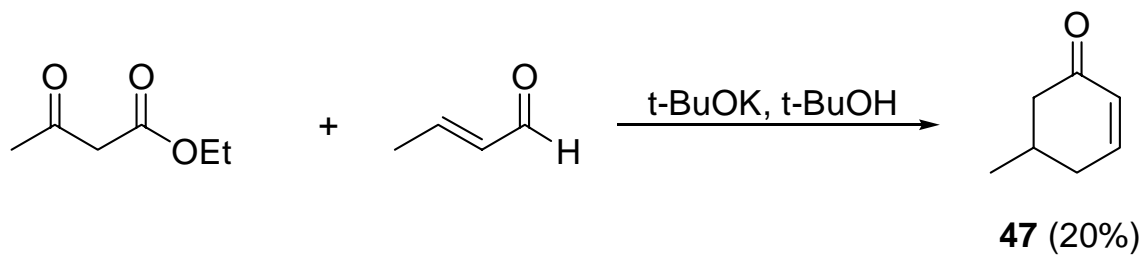

Bromobenzocycloheptenone $\mathbf{5 2}$ was prepared from 1-benzosuberone (48) according to Scheme 16. The silyl enol ether $\mathbf{4 9}$ was converted to benzocycloheptenone $\mathbf{5 0}$ by a palladiumcatalyzed dehydrosilylation reaction. ${ }^{20}$ Compound $\mathbf{5 2}$ was then prepared via a literature procedure consisting of a two step bromination-dehydrobromination sequence. ${ }^{21}$ 


\section{Scheme 16}

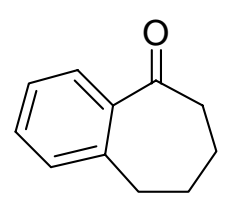

48

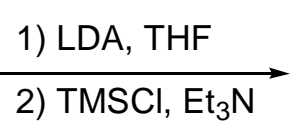

49 (95\%)

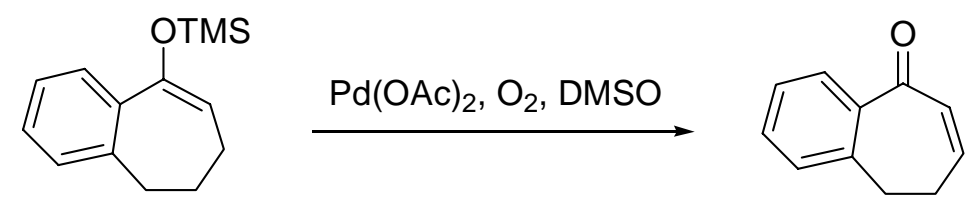

$50(93 \%)$<smiles>O=C1C(Br)=CCCc2ccccc21</smiles>

Nitrobenzenes $\mathbf{2 6}$ and $\mathbf{2 8}$ were commercially available. Compounds $\mathbf{2 7}$ and $\mathbf{3 0}$ were previously synthesized in our laboratory according to literature procedures. ${ }^{9,}{ }^{10}$ Compounds 29 and 31 were prepared by the Sandmeyer type reactions of their corresponding anilines (Scheme 17).

\section{Scheme 17}

$\overbrace{\mathrm{NH}_{2}}^{\mathrm{NO}_{2}} \frac{\text { 1) } \mathrm{H}_{2} \mathrm{SO}_{4}, \mathrm{H}_{2} \mathrm{O}, \mathrm{NaNO}_{2}}{\text { 2) } \mathrm{Kl}, \mathrm{H}_{2} \mathrm{O}, \mathrm{Cu}}$

53

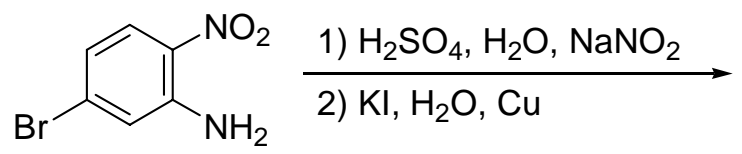

54<smiles>Cc1cccc(I)c1[N+](=O)[O-]</smiles>

$29(88 \%)$<smiles>O=[N+]([O-])c1ccc(Br)cc1I</smiles>

31 (61\%) 
With the preparation of several substituted 2-(2-nitrophenyl)-2-cycloalkenones we now had sufficient substrates ready to test the scope of the reductive cyclization reaction. Our first attempted $N$-heteroannulation of $\mathbf{3 2}$ using palladium diacetate ( $6 \mathrm{~mol} \%$ ), triphenylphosphine (24 mol\%), and carbon monoxide ( $4 \mathrm{~atm})$ in acetonitrile at $70{ }^{\circ} \mathrm{C}$ surprisingly gave only starting material. Since it is known that palladium phenanthroline complexes are particularly active catalysts for the reductive carbonylation of nitrobenzenes forming isocyanates,${ }^{22}$ we chose to modify our cyclization conditions to those shown in Scheme 18. The expected 1,2-dihydro4(3H)-carbazolone (5) was obtained in good isolated yield using Pd(dba) $)_{2}(6 \mathrm{~mol} \%)$, dppp (1,3bis(diphenylphosphino)propane) (6 mol\%), 1,10-phenanthroline monohydrate (12 mol\%), and carbon monoxide (90 psi) in DMF at $80{ }^{\circ} \mathrm{C}$.

Next we tested these promising reaction conditions on the substrates shown in Table 1. Results of these reductive cyclizations are summarized in Table 2. All reactions proceeded smoothly affording excellent yields of products. Five-membered to seven-membered cycloalkenones all gave good results. Substitution on the cycloalkenone ring was also well tolerated in the reaction. The presence of electron donating or withdrawing groups at various positions on the aryl ring also presented no problems with the $N$-heteroannulation.

\section{Scheme 18}<smiles>O=C1CCCC=C1c1ccccc1[N+](=O)[O-]</smiles>

32
$\operatorname{Pd}(\mathrm{dba})_{2}, \mathrm{dppp}$ $\underset{\mathrm{CO}(90 \mathrm{psi}), \mathrm{DMF}, 80^{\circ} \mathrm{C}}{\stackrel{1,10-\text { Phenanthroline monohydrate }}{\longrightarrow}}$

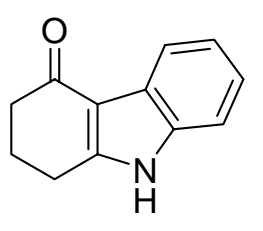

$5(74 \%)$ 
Most of the reductive cyclizations were complete in 1-3 days. However, substrate 41 required an extended period of 8 days to go to completion. The yield of the bromocarbazolone $\mathbf{6 3}$ also was slightly lower than the other cyclizations. 4-Bromo substitution has previously been problematic in this type of reaction. The attempted cyclization of the related substrate, bromonitrostyrene $\mathbf{6 4}$, performed previously in our laboratory yielded only starting material (Scheme 19). ${ }^{9}$

Table $2^{\mathrm{a}}$<smiles>O=C1CCCC=C1c1ccccc1[N+](=O)[O-]</smiles>

32<smiles>CC1CC=C(c2ccccc2[N+](=O)[O-])C(=O)C1</smiles>

33<smiles>O=C1CCC=C1c1ccccc1[N+](=O)[O-]</smiles>

34<smiles>O=C1CCCCC=C1c1ccccc1[N+](=O)[O-]</smiles>

35<smiles>O=C1C(c2ccccc2[N+](=O)[O-])=CCCc2ccccc21</smiles>

36<smiles>O=C1CCCc2[nH]c3ccccc3c21</smiles>
5 (74\%)<smiles>CC1CC(=O)c2c([nH]c3ccccc23)C1</smiles>

55 (89\%)

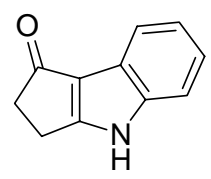

56 (86\%)<smiles>O=C1CCCCc2[nH]c3ccccc3c21</smiles>

57 (66\%)

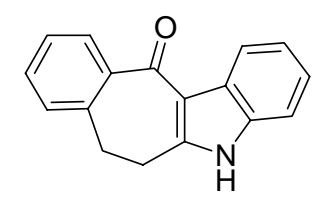

$58(86 \%)$ 
Table 2 continued

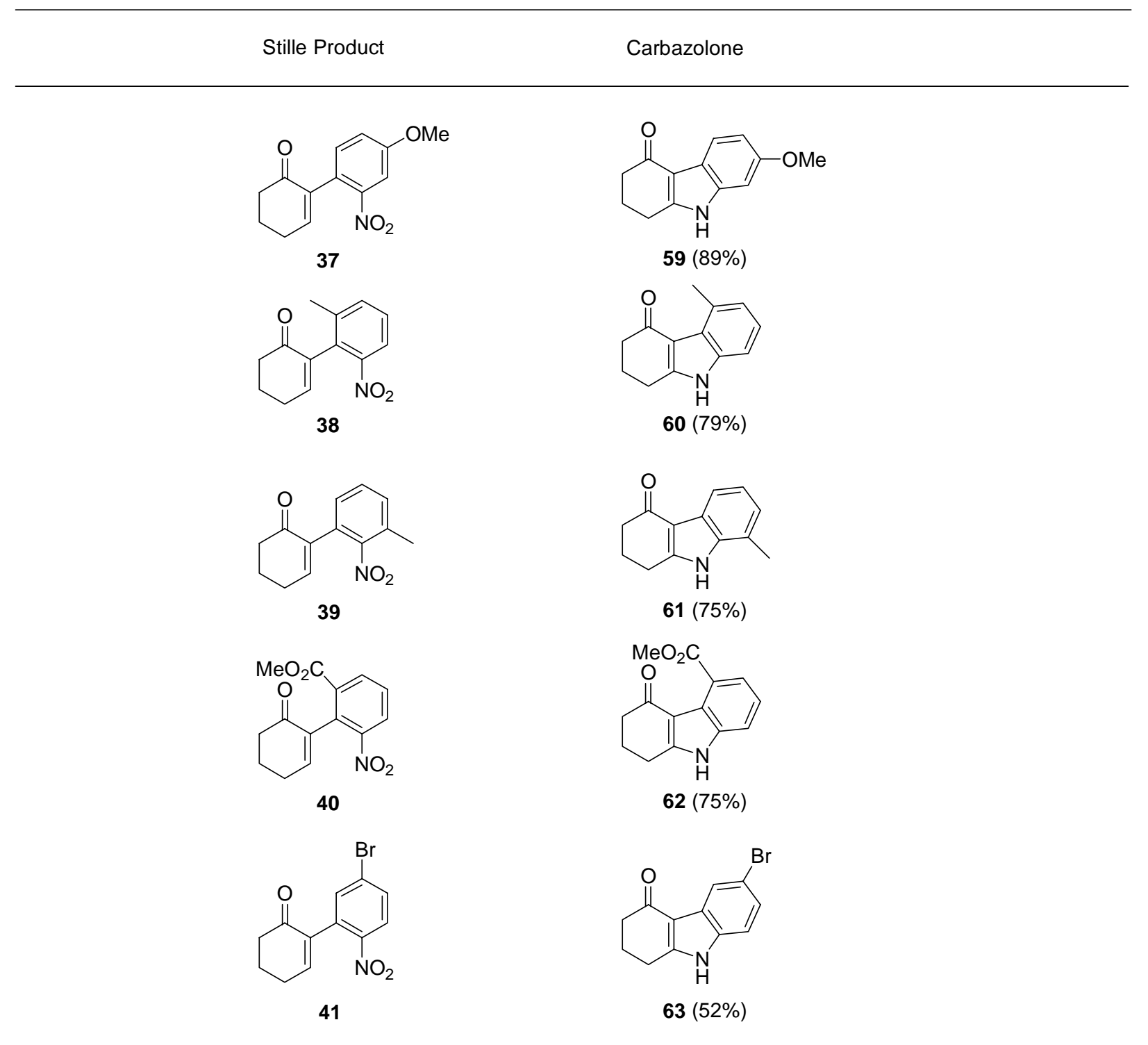

a) General conditions: $\mathrm{Pd}(\mathrm{dba})_{2}(6 \mathrm{~mol} \%)$, dppp $(6 \mathrm{~mol} \%), 1,10$-Phenanthroline monohydrate $(12 \mathrm{~mol} \%)$, $\mathrm{CO}(90 \mathrm{psi})$, DMF, $80^{\circ} \mathrm{C}$. For more exact details see: Experimental Section.

\section{Scheme 19}

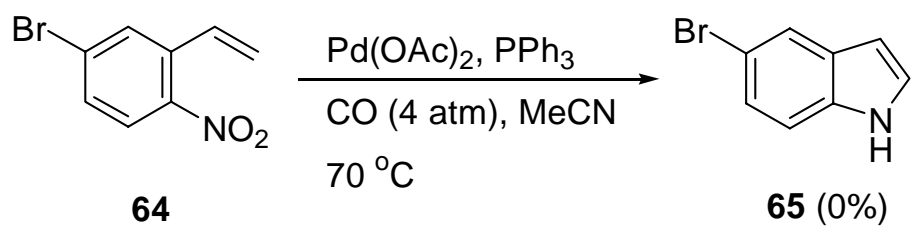


The formation of $\mathbf{5 8}$ is of substantial synthetic interest. Benzocycloheptaindole derivatives are being studied for their antitumor potential. ${ }^{8}$ This reaction could be useful for the preparation of such compounds.

The cyclization reactions are typically monitored by thin layer chromatography. Progress of the reactions can also be determined by ${ }^{1} \mathrm{H}$ NMR. Cyclization products are distinguishable from starting materials by certain NMR characteristics including the presence of a broad N-H peak between 8 and $11 \mathrm{ppm}$ and the disappearance of the triplet $\mathrm{C}-\mathrm{H}$ signal of the starting material. For example, carbazolone 5 has a distinct $\mathrm{N}-\mathrm{H}$ signal at $8.55 \mathrm{ppm}$ and the $\mathrm{C}-\mathrm{H}$ triplet at 6.98 of the starting material 32 has disappeared.

New synthetic analogs of carbazoles are currently being investigated for their modified biological activity. For this reason we decided to apply our reductive cyclization reaction toward the synthesis of an azacarbazole (Scheme 20). We constructed the cyclization precursor 67 via a Stille coupling reaction of 2-chloro-3-nitropyridine (66) and stannane 24. The Stille product 67 could not be isolated in any significant amount, although the crude NMR indicated that the reaction was working well. We were convinced that the isolation problem was due to extensive decomposition upon purification by silica gel chromatography. We were unable to isolated the product in any yield greater that $33 \%$ after column chromatography. Therefore, we opted to carry on the crude Stille product to the cyclization reaction. This proved to be a good decision providing the azacarbazole $\mathbf{6 8}$ in $54 \%$ yield over two steps.

In a search for alternative substrates for the cyclization reaction we discovered an additional route to 1,2-dihydro-4(3H)-carbazolone (5). 2-(2-Nitrophenyl)-1,3-cyclohexanedione (70) and 3-methoxy-2-(2-nitrophenyl)-2-cyclohexenone (71), derived from 1,3cyclohexanedione $^{23}(\mathbf{6 9})$, both gave the carbazolone product 5 in good yields, although reaction 
times were much longer compared to the reductive cyclization of $\mathbf{3 2}$ even at elevated temperatures (Scheme 21).

\section{Scheme 20}<smiles>CCCSC1=CCCCC1=O</smiles>

24

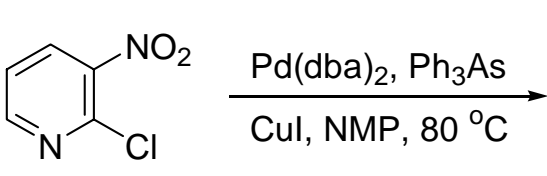

66<smiles>O=C1CCCC=C1c1ncccc1[N+](=O)[O-]</smiles>

67

$$
\begin{aligned}
& \underset{\mathrm{Pd}(\mathrm{dba})_{2}, \mathrm{dppp}}{\text { 1,10-Phenanthroline }} \\
& \text { CO (90 psi), DMF, } 80{ }^{\circ} \mathrm{C}
\end{aligned}
$$<smiles>O=C1CCCc2[nH]c3cccnc3c21</smiles>

68 (54\%, two steps)

\section{Scheme 21}<smiles>O=C1CCCC(=O)C1</smiles>

69<smiles>O=[N+]([O-])C1=C(I)C=C[C+]=C1</smiles>

26

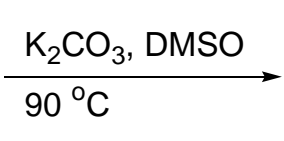<smiles>O=C1CCCC(O)=C1c1ccccc1[N+](=O)[O-]</smiles><smiles>[18OH][18OH]</smiles>

$\mathrm{Pd}(\mathrm{dba})_{2}, \mathrm{dppp}$ $\underset{\mathrm{CO}(90 \mathrm{psi}), \mathrm{DMF}}{\stackrel{10-P h e n a n t h r o l i n e}{ }}$ $100{ }^{\circ} \mathrm{C}, 138 \mathrm{~h}$

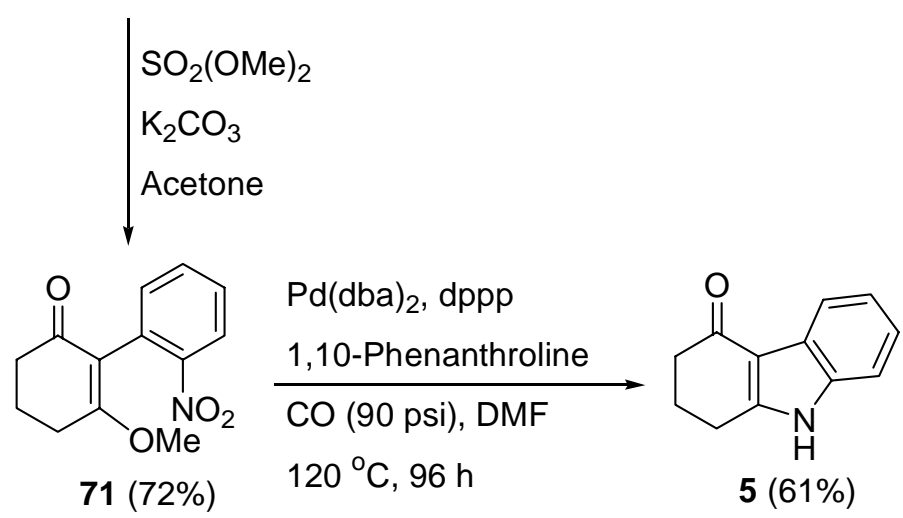


At this time the mechanism for the reductive cyclization reaction remains unknown. It is very unlikely that the reaction proceeds by initial reduction of the nitro group to an amine followed by an amino-palladation $\beta$-hydride elimination sequence as in the Hegedus indole synthesis. ${ }^{24}$ This type of reaction requires a palladium (II) catalyst which has to be regenerated by an added oxidant. No oxidant is present in these cyclization reactions. There are also mechanistic studies indicating that the formation of aniline is insignificant in the formation of indoles. $^{25}$ Additional evidence against the role of aniline in the carbazolone reactions is that the direct reduction of the nitro group in 2-(2-nitrophenyl)-2-cyclohexenones by palladium-catalyzed hydrogenation does not produce carbazolones. The results of this study are presented in part III.

Watanabe et al have proposed through some mechanistic studies that the reaction proceeds through the formation of an active transition metal nitrene intermediate followed by an insertion reaction. ${ }^{26,11}$ Although no metal-bound nitrene intermediates have been isolated in the indole syntheses, the reaction of 2-nitrobiphenyl (72) using $\mathrm{Ru}_{3}(\mathrm{CO})_{13}$ produced the rutheniumbound nitrene 73 (Scheme 22). ${ }^{27}$ The structure of 73 was determined by X-ray crystallography. When treated with carbon monoxide $\mathbf{7 3}$ gives carbazole as well as 2-aminobiphenyl. This evidence supports the theory that a nitrene intermediate is involved in the synthesis of indoles.

\section{Scheme 22}<smiles>O=[N+]([O-])c1ccccc1-c1ccccc1</smiles>

72

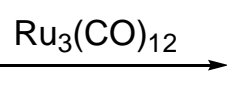<smiles>O=C(O)C(=O)Nc1ccccc1-c1ccccc1</smiles>

73 
One possible mechanism to a nitrenoid intermediate by a deoxygenative sequence is presented in Scheme 23. Palladium addition to the nitro group followed by carbon monoxide insertion and elimination of carbon dioxide could give a palladium-nitroso intermediate. Another insertion by carbon monoxide and subsequent elimination of carbon dioxide gives the palladium-bound nitrene. Insertion into the $\mathrm{C}-\mathrm{H}$ bond of the cyclohexenone by the nitrene can follow to give the carbazolone product.

\section{Scheme 23}

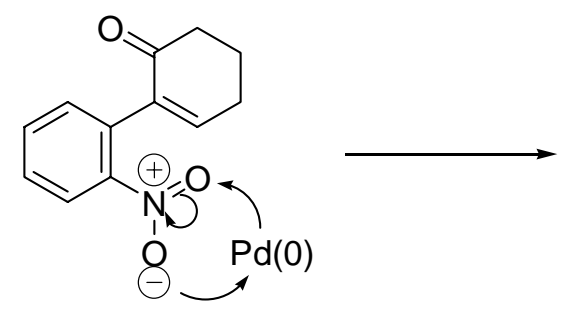<smiles>O=C1CCCC=C1c1ccccc1NOPO</smiles><smiles>O=C1CCCC=C1c1ccccc1N1OP(=O)(O)O1</smiles><smiles>[3H]C(=O)OC</smiles><smiles>O=C1CCCC=C1c1ccccc1N=[OH+]</smiles><smiles>[14CH]=O</smiles><smiles>O=C1CCCC=C1c1ccccc1-n1oc(=O)o1</smiles><smiles>CC(C)=O</smiles><smiles>O=C1CCCC=C1c1ccccc1N1CO1</smiles>

\section{Conclusions}

We have successfully developed a mild and efficient method of preparing functionalized carbazolones. This novel route consists of two sequential palladium-catalyzed reactions, an intermolecular Stille coupling followed by a reductive $N$-heterocyclization. Many functional 
groups and ring sizes are well tolerated in these reactions. This novel procedure has been applied to the synthesis of naturally occurring carbazole alkaloids presented in the next section. 


\section{Part II}

\section{Formal Total Syntheses of Carbazole Alkaloids}

\section{Introduction}

Carbazole alkaloids are of great interest due to their numerous biological activities. For example, these natural products show antitumor, antibiotic, and antifungal properties, as well as having an inhibitory effect on mitosis and activity against malaria. ${ }^{28}$ Many carbazole alkaloids have been isolated from plants belonging to the Rutaceae family. Most of these compounds have a one-carbon substituent in the 3-position and an oxygen functionality in the 1- or 2-position. Dimeric and quinoid structures are also known in this group. We have been interested in a number of these natural products, many of which are from plants of the genus Murraya. These plants consist of small trees and shrubs endemic to Southern Asia that have been used for years in folk medicine for analgesics and treatment of ailments such as eczema and rheumatism. ${ }^{29}$

Figure 4 shows a few of the carbazole alkaloids that have been of synthetic interest to us. Murrayaquinone $\mathrm{A},{ }^{30}$ murrayafoline $\mathrm{A},{ }^{30}$ and dimeric $O$-demethylmurrayafoline $\mathrm{A}^{31}$ are examples of alkaloids isolated from Murraya euchrestifolia Hayata. Murrayaquinone A is known to induce myocardial contraction. Dimeric $O$-demethylmurrayafoline A exhibits antiplasmodial activity against $P$. falciparum in vitro. Murrayanine ${ }^{32}$ and koenigine-quinone $\mathrm{A}^{33}$ were both isolated from Murraya koenigii Spreng (Figure 5). ${ }^{34}$ Murraya koenigii Spreng is commonly known as the Indian curry tree. The leaves which have a distinct odor of anise are widely used as a flavoring in Indian curries. (+)-Aspidospermidine ${ }^{35}$ has been found in plants of the Aspidosperma genus. While aspidospermidine in itself doesn't possess any significant 
biological properties, alkaloids with similar ring structures are known to have antitumor activity. Therefore, it can be considered a model for the design of new synthetic approaches toward these more functionalized compounds.

\section{Figure 4}

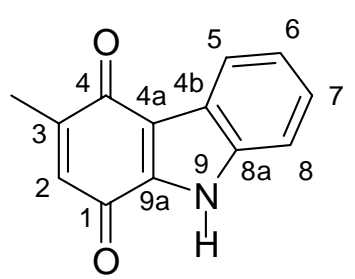

Murrayaquinone A<smiles>COc1cc(C)cc2c1[nH]c1ccccc12</smiles>

Murrayafoline A<smiles>Cc1cc2c([nH]c3ccccc32)c(O)c1-c1c(C)cc2c([nH]c3ccccc32)c1O</smiles>

Dimeric O-demethylmurrayafoline A<smiles>COc1cc(C=O)cc2c1[nH]c1ccccc12</smiles>

Murrayanine<smiles>COc1ccc2c3c([nH]c2c1)C(=O)C=C(C)C3=O</smiles>

Koenigine-quinone $\mathrm{A}$

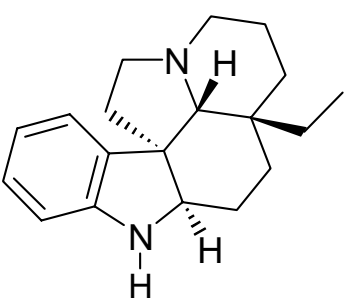

(+) - Aspidospermidine

Figure 5

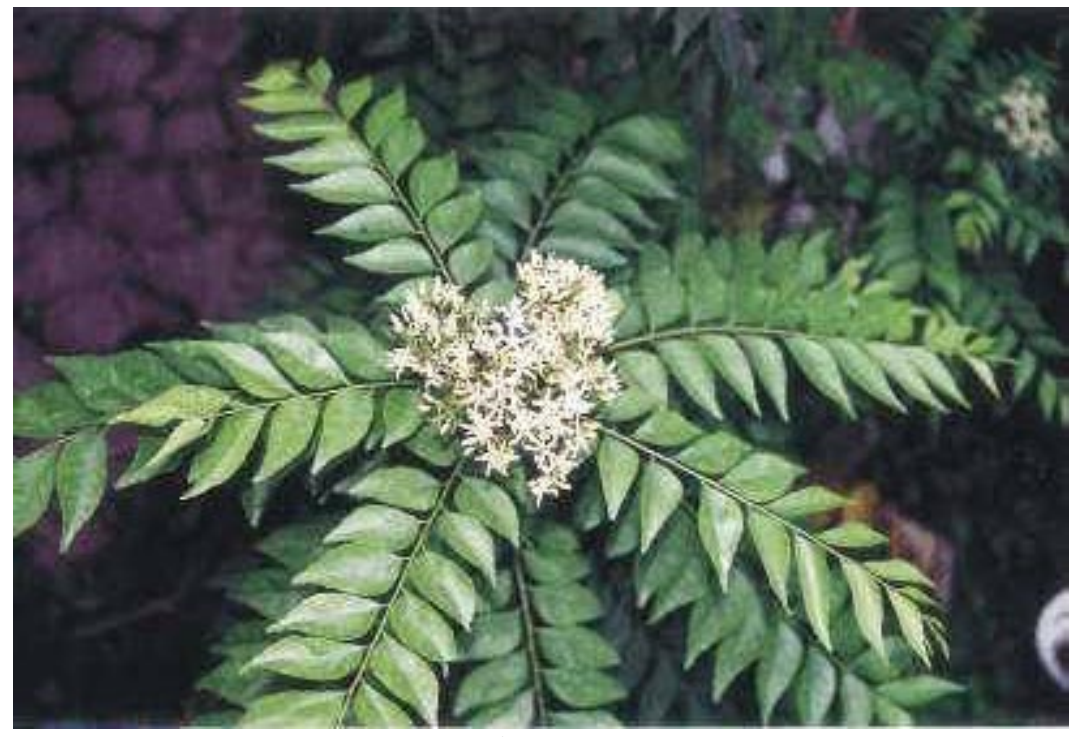

Murraya koenigii Spreng 
There have been several syntheses of these carbazole alkaloids presented in the literature. One common approach to carbazoles is via the Fischer method. Murrayanine and murrayafoline A were prepared in this manner (Scheme 24). ${ }^{32}$ The Fischer indole synthesis was used to prepare carbazolone 1 which was converted to carbazole 75 via dehydrogenation. Methylation produced murrayafoline A, followed by bromination and then hydrolysis with $\mathrm{KOH}$ to compound $\mathbf{7 6}$. Manganese dioxide oxidation of $\mathbf{7 6}$ produced the product, murrayanine.

\section{Scheme 24}

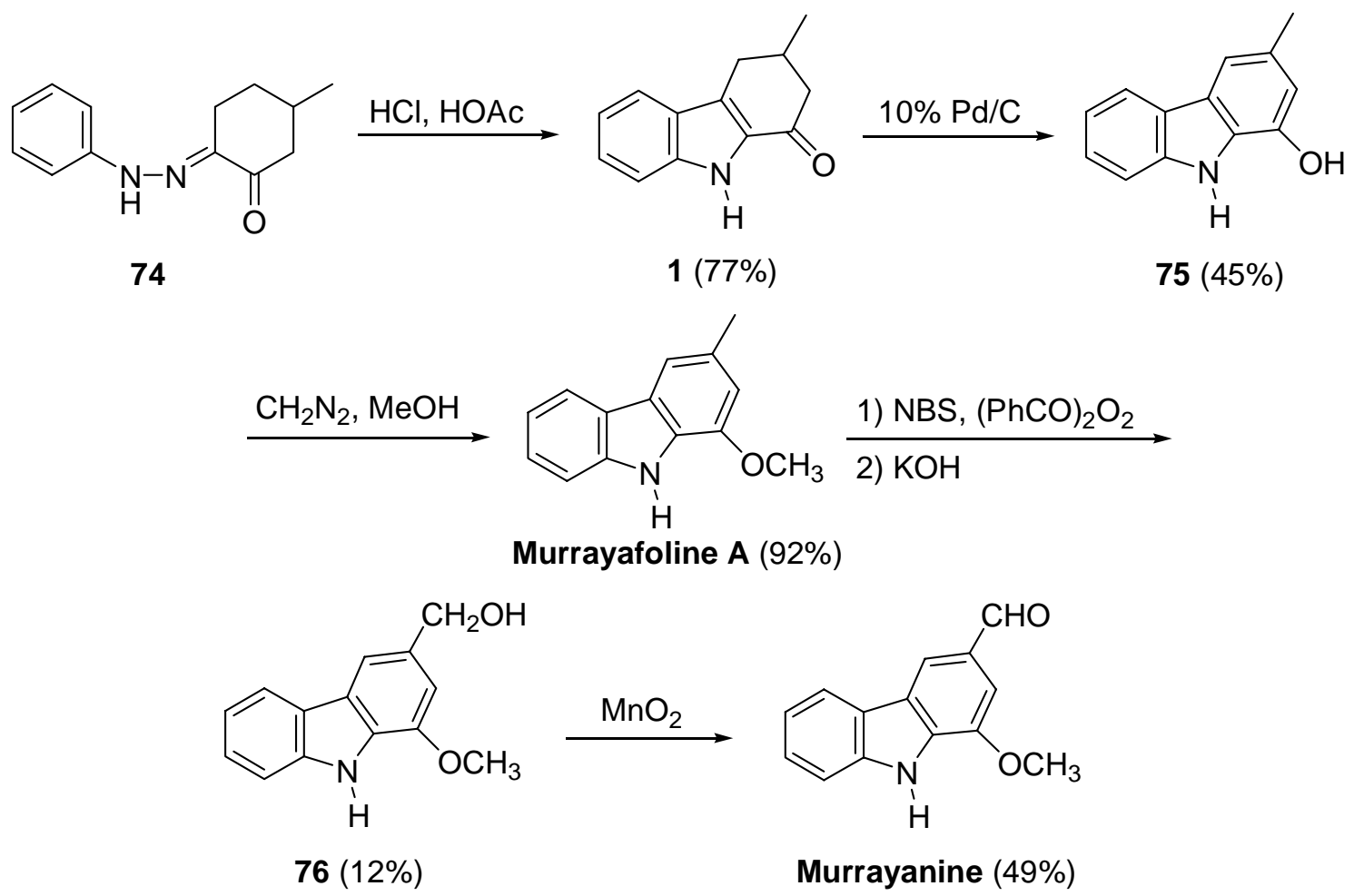

Murrayafoline A and murrayaquinone A have also been synthesized by a similar approach (Scheme 25). ${ }^{36}$ The key carbazole intermediate $\mathbf{7 8}$ along with a small amount of 79 was also produced by the Fischer method. Dehydrogenation of tetrahydrocarbazole $\mathbf{7 8}$ to the 
carbazole 80, followed by hydrolysis of the mesyl group gave $\mathbf{8 1}$. Compound $\mathbf{8 1}$ could then be converted either to murrayafoline A by methylation, or to murrayaquinone A by oxidation.

\section{Scheme 25}

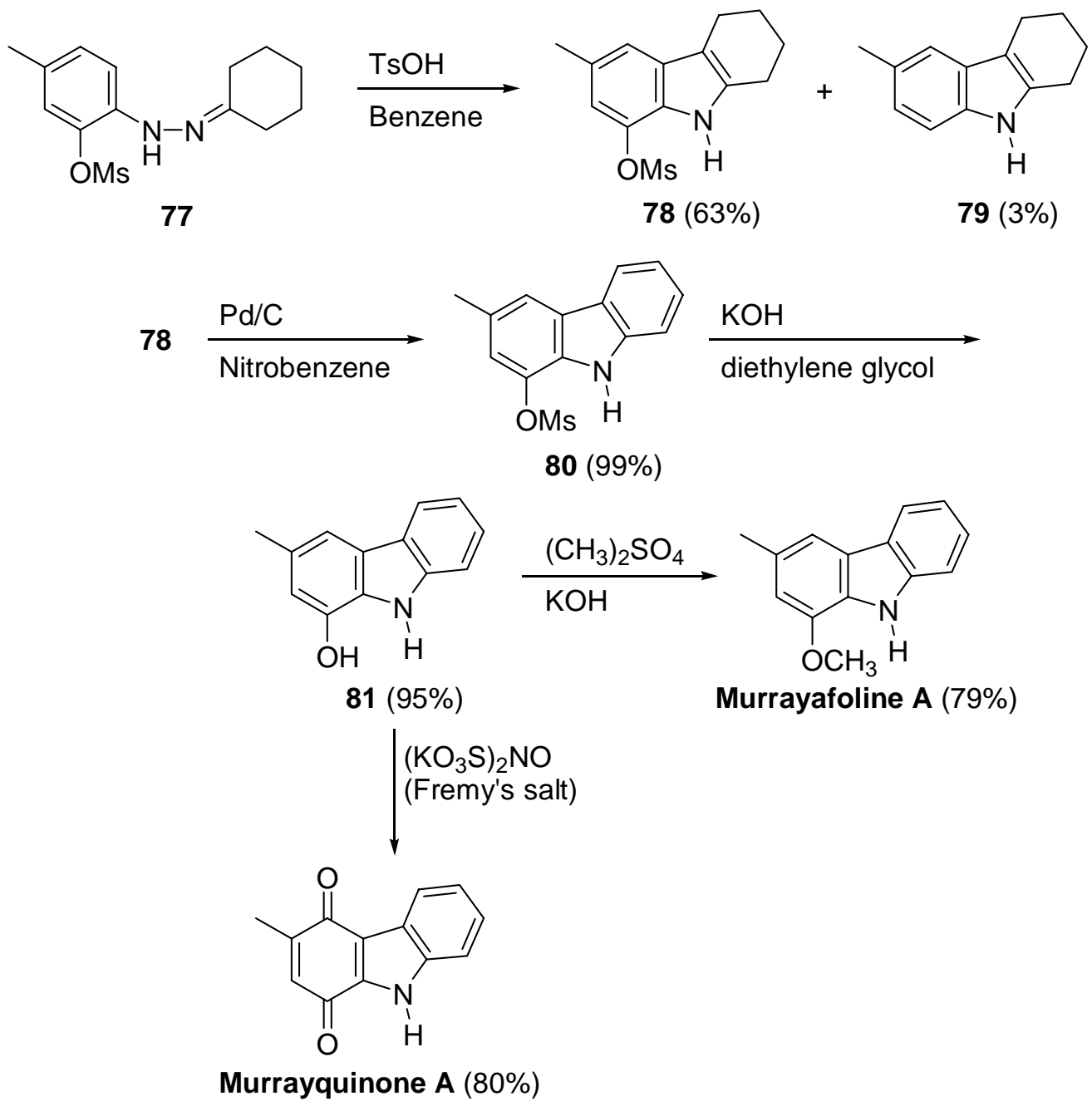

Koenigine-quinone A also was synthesized via a Fischer indole synthesisdehydrogenation-oxidation sequence (Scheme 26). ${ }^{33}$ 


\section{Scheme 26}<smiles>COc1cccc(NN=C2CCC(C)CC2=O)c1</smiles>

82

$83(66 \%)$<smiles>COc1ccc2c(c1)[nH]c1c(O)cc(C)cc12</smiles>

$84(66 \%)$<smiles>COc1ccc2c3c([nH]c2c1)C(=O)C=C(C)C3=O</smiles>

Koenigine-quinone A (77\%)

\section{Scheme 27}<smiles>O=Cc1c[nH]c2ccccc12</smiles>

85

\section{$\frac{\text { 1) } \mathrm{Boc}_{2} \mathrm{O}, \mathrm{DMAP}, \mathrm{CH}_{2} \mathrm{Cl}_{2}}{\text { 2) } 86, \mathrm{NaH}, \mathrm{THF}}$}

2) $86, \mathrm{NaH}, \mathrm{THF}$<smiles>CCOC(=O)/C(=C/c1cn(C(=O)OC(C)(C)C)c2ccccc12)CC(=O)O</smiles>

87 (66\%)<smiles>CCOC(=O)c1cc(OC)c2[nH]c3ccccc3c2c1</smiles><smiles>COc1cc(C)cc2c1[nH]c1ccccc12</smiles>

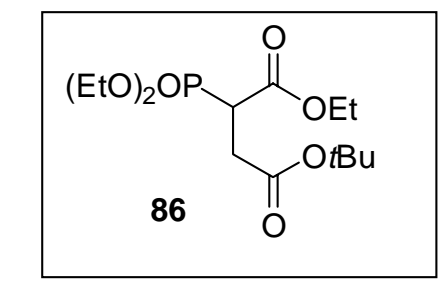

Murrayafoline A (80\%)

1) $\mathrm{TFA}, \mathrm{CH}_{2} \mathrm{Cl}_{2}$

2) $\mathrm{NaOAc}, \mathrm{Ac}_{2} \mathrm{O}$

4) $\mathrm{DMS}, \mathrm{K}_{2} \mathrm{CO}_{3}$, acetone 
$O$-methylation gave $\mathbf{8 8}$. Carbazole $\mathbf{8 8}$ was converted to murrayafoline A by lithium aluminum hydride reduction.

Moody et al have developed a method toward 1-oxygenated carbazoles starting from indole-2-carboxylates (Scheme 28). ${ }^{37}$ Murrayafoline A was formed from indole-2-carboxylate $\mathbf{8 9}$ by condensation with 4-methylbutyrolactone to give lactone $\mathbf{9 0}$, followed by hydrolysis and decarboxylation to alcohol 91, and then oxidation to aldehyde $\mathbf{9 2}$. Aldehyde $\mathbf{9 2}$ cyclized to murrayafoline A upon treatment with boron trifluoride-methanol. Murrayafoline A was converted to murrayaquinone A via a two step demethylation-oxidation sequence.

\section{Scheme 28}<smiles>CC(=O)c1cc2ccccc2[nH]1</smiles>

89

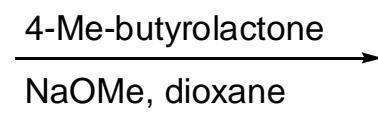

$\mathrm{NaOMe}$, dioxane

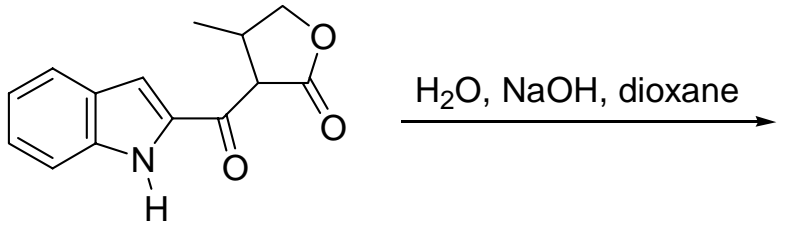

$90(72 \%)$

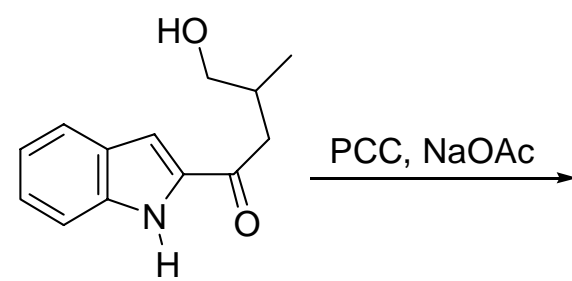

91 (73\%)<smiles>COc1cc(C)cc2c1[nH]c1ccccc12</smiles>

Murrayafoline A (58\%)

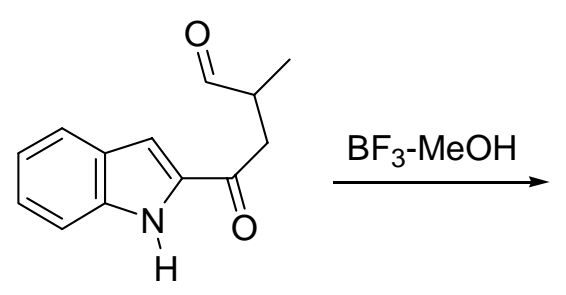

92 (83\%)

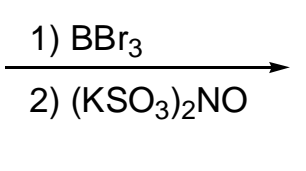

Murrayaquinone A (40\%)

Some other synthetic methods to key intermediates of murrayaquinone A include the novel Diels-Alder approach by Miki et $a l^{38}$ (Scheme 29), the thermal electrocyclization reactions 
by Hibino and coworkers ${ }^{39}$ (Scheme 30), and the annulations of bromo-1,4-benzoquinones and enaminones presented by Murphy et al ${ }^{40}$ (Scheme 31).

\section{Scheme 29}<smiles>CCCCCOc1occ2c1c1ccccc1n2Cc1ccccc1</smiles>

93

$$
\text { (1) }
$$
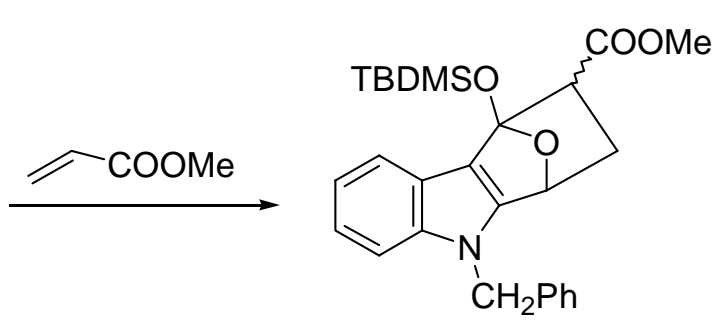

94<smiles>CCOc1ccc2c(c1O)c1ccccc1n2Cc1ccccc1</smiles>

$95(87 \%)$

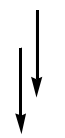

Murrayaquinone A

Scheme 30<smiles>C#CC(OC)c1c(C=C)n(C(OC)OC)c2ccccc12</smiles>

96<smiles>CO[R6]n1c2ccccc2c2c(OC)c(C)ccc21</smiles>

$97(81 \%)$

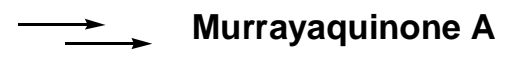

\section{Scheme 31}<smiles>CC1=CC(=O)C(Br)=CC1=O</smiles> 
Åkermark and coworkers ${ }^{41}$ have also reported the palladium-catalyzed oxidative cyclization of 2-arylamino-1,4-quinones to yield several carbazole alkaloids including murrayaquinone A (Scheme 32).

\section{Scheme 32}

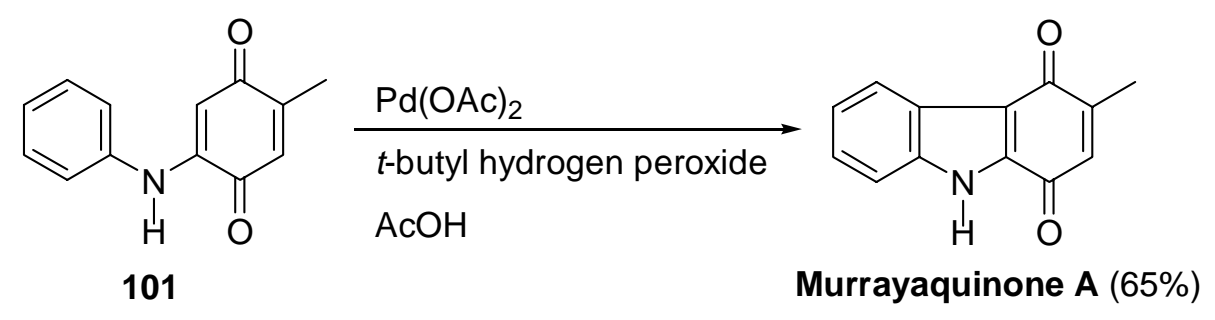

Another metal-mediated reaction toward the synthesis of carbazoles was developed by Knölker and coworkers ${ }^{42}$ (Scheme 33). They use an electrophilic aromatic substitution such as that of aniline $\mathbf{1 0 3}$ with a cyclohexadienyltricarbonyliron cation as the key step in the synthesis of several carbazoles.

\section{Scheme 33}

$(\mathrm{OC})_{3} \mathrm{Fe}$<smiles>Ic1ccccc1</smiles>

$\mathrm{BF}_{4}$

102<smiles></smiles>

103

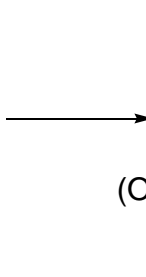

$$
(\mathrm{OC})_{3}
$$<smiles>COc1cccc(C2C=CC(C(F)(F)F)=CC2)c1N</smiles>

104

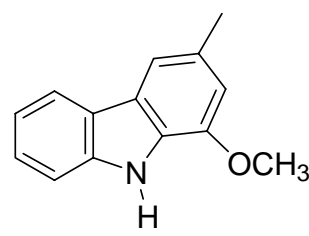

Murrayafoline A

Dimeric alkaloids such as dimeric $O$-demethylmurrayafoline A have been produced via the oxidative couplings of carbazole monomers (Scheme 34). ${ }^{43}$ 


\section{Scheme 34}<smiles>Cc1cc(O)c2c(c1)c1ccccc1n2CCO</smiles><smiles>Cc1cc2c([nH]c3ccccc32)c(O)c1-c1c(O)cc2c([nH]c3ccccc32)c1C</smiles>

Dimeric O-demethylmurrayafoline A (87\%)

\section{Scheme 35}

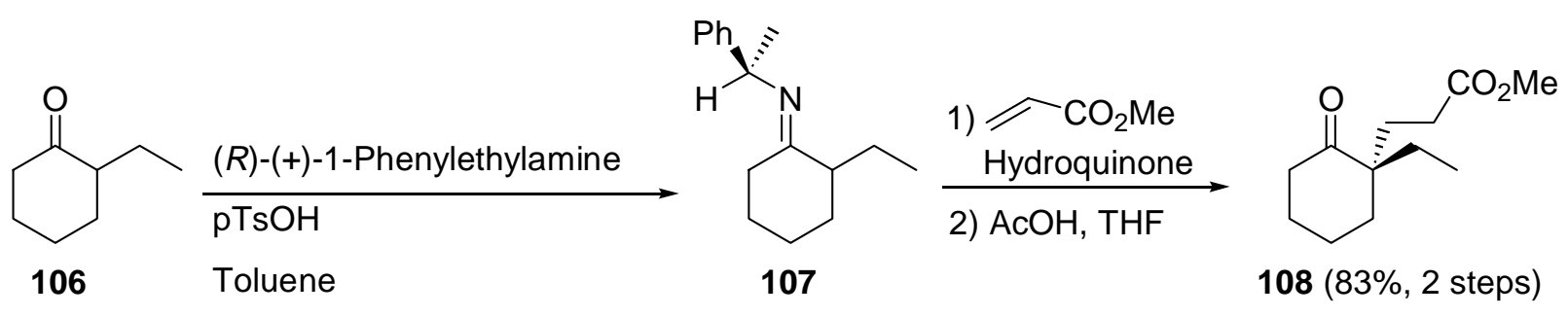

1) $\mathrm{Et}_{3} \mathrm{~N}, \mathrm{DMF}, \mathrm{TMSCl}$

2) $D D Q, 2,6$-lutidine, Toluene<smiles>CC[C@]1(CCC(C)=O)CCC=CC1=O</smiles>

1) $\mathrm{Et}_{3} \mathrm{~N}, \mathrm{PhSH}$

$\underset{\text { 2) } \mathrm{N} \text {-Chlorosuccinimide }}{\stackrel{\mathrm{NaOMe}, \mathrm{MeOH}}{\longrightarrow}}$

$109(78 \%)$

4) $\mathrm{HCl}, \mathrm{THF}$<smiles>CC[C@]1(CCC(C)=O)CCC(=O)CC1=O</smiles>

$110(45 \%)$<smiles>Nc1ccccc1I</smiles>

Toluene<smiles>CC[C@]1(CCC(C)=O)CCC(Nc2ccccc2I)=CC1=O</smiles>

$\underset{\text { 1) } \mathrm{NaH}, \mathrm{HMPA}}{\stackrel{\mathrm{Cul}}{\longrightarrow}}$<smiles>CC[C@]1(CCC(C)=O)CCc2[nH]c3ccccc3c2C1=O</smiles>

$112(84 \%)$

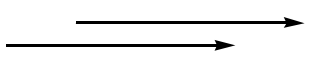

A

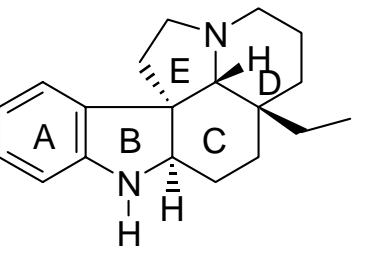

(+)-Aspidospermidine 
The $[\mathrm{ABC}]$-type subunit in (+)-aspidospermidine has been constructed using a copper(I)iodide-promoted arylation originally reported by $\mathrm{Suzuki}^{44}$ in the synthesis by Desmaele and d'Angelo (Scheme 35). ${ }^{35}$ The critical stereochemistry at the CD ring junction was set by the asymmetric Michael addition of chiral imine $\mathbf{1 0 7}$ to methyl acrylate. The ee obtained in this reaction was only $86 \%$, but the optical purity of $\mathbf{1 0 8}$ could be efficiently upgraded through semicarbazone derivatization and crystallization. The synthesis of dione $\mathbf{1 1 0}$ was carried out in several steps from 108. The preparation of intermediate $\mathbf{1 1 2}$ was achieved by condensation of 110 with 2-iodoaniline, followed by cyclization of the enaminone 111. This synthesis of (+)aspidospermidine was completed in a linear sequence of 22 steps from 2-ethylcyclohexanone with a $2.7 \%$ overall yield.

While there are many methods for preparing carbazoles, these methods are not without limitations. Some of the traditional methods lack regioselectivity, and the conditions employed are too harsh for some sensitive functional groups. Another limitation is the availability of starting materials for these transformations. Upon developing our method for the synthesis of carbazolones presented in the previous section we decided to apply our approach to the synthesis of natural products. Regioselectivity is not a problem in our method, and a number of functional groups are tolerated in these reactions. The availability of starting materials has also not been a difficulty. The formal total syntheses of several naturally occurring carbazole alkaloids is presented. 


\section{Results and Discussion}

\subsection{Formal Total Synthesis of Murrayaquinone A}

Carbazolequinones have been efficiently synthesized via the oxidation of

hydroxycarbazole precursors as previously described. It is known in the literature ${ }^{38,45}$ that 3methyl-4-hydroxycarbazole can be oxidized to murrayaquinone A using Fremy's salt $\left(\left(\mathrm{KO}_{3} \mathrm{~S}\right)_{2} \mathrm{NO}\right)$ in excellent yield $(83 \%)$. Therefore, we decided that a potentially useful route to the alkaloid would be through carbazolone 116 (Scheme 36). Dehydrogenation of 116 would lead to hydroxycarbazole $\mathbf{1 1 7}$, thus completing the formal total synthesis of murrayaquinone A.

\section{Scheme 36}<smiles>CC1CCC=CC1=O</smiles>

113

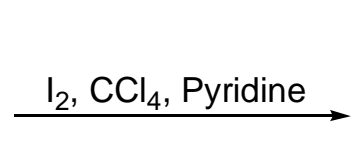<smiles>CC1CCC=C(I)C1=O</smiles>

$114(71 \%)$<smiles>CCCCc1ccccc1N(CCCC)C(=O)OCC</smiles>
$\mathrm{Ph}_{3} \mathrm{As}, \mathrm{Cul}$ NMP, $80{ }^{\circ} \mathrm{C}$<smiles>CC1CCC=C(c2ccccc2[N+](=O)[O-])C1=O</smiles>

115 (87\%)

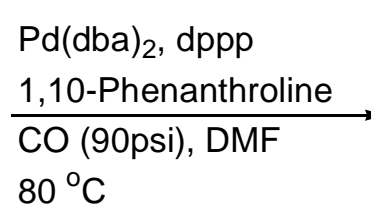<smiles>CC1CCc2[nH]c3ccccc3c2C1=O</smiles>

$\underset{1,2,4 \text {-trimethylbenzene }}{\stackrel{10 \%}{\mathrm{Pd} / \mathrm{C}, \mathrm{Ph}_{2} \mathrm{O}}}$ $230{ }^{\circ} \mathrm{C}$

$116(97 \%)$<smiles>Cc1ccc2[nH]c3ccccc3c2c1O</smiles>

117 (63\%)<smiles>CC1=CC(=O)c2[nH]c3ccccc3c2C1=O</smiles>

Murrayaquinone A

Carbazolone 116 was prepared according to our method previously described, a Stille coupling followed by a $N$-heteroannulation reaction. 2-Iodo-6-methyl-cyclohexen-1-one (114) 
was prepared from cyclohexenone $\mathbf{1 1 3}$ in $71 \%$ yield by the iodination method previously described in Scheme 14. The Stille reaction of $\mathbf{1 1 4}$ and stannane 25 in the presence of $\mathrm{PdCl}_{2}(\mathrm{PhCN})_{2}, \mathrm{Ph}_{3} \mathrm{As}$, and $\mathrm{CuI}$ in $\mathrm{NMP}$ at $80{ }^{\circ} \mathrm{C}$ gave 115 in an excellent yield of $87 \%$. The reductive cyclization of $\mathbf{1 1 5}$ also proceeded in an excellent yield (97\%) of carbazolone 116. The dehydrogenation reaction of carbazolone 116 using $10 \% \mathrm{Pd} / \mathrm{C}$ in a mixture of diphenyl ether and 1,2,4-trimethylbenzene at $230{ }^{\circ} \mathrm{C}$ gave hydroxycarbazole 117. It was discovered that the addition of a small amount of 1,2,4-trimethylbenzene was critical for the dehydrogenation to occur. $^{31}$

Our synthesis of the murrayaquinone A precursor 116 is much more efficient and higher yielding than the synthesis by Miki et al. ${ }^{38}$ Their synthesis took nine steps from dimethyl indole2,3-dicarboxylate with an overall yield less than $16 \%$. Our synthesis was completed in only four steps from 6-methyl-2-cyclohexen-1-one with an overall yield of $38 \%$.

\subsection{Formal Synthesis of Four Carbazole Alkaloids}

While working on our first synthesis of murrayaquinone A, we were also investigating an alternative route to this compound via carbazolone $\mathbf{1}$ (Scheme 37). We applied the conditions to prepare $\beta$-iodo- $\alpha, \beta$-unsaturated ketones originally developed by Piers and Nagakura ${ }^{46}$ to prepare 3-iodo-5-methyl-2-cyclohexen-1-one (119). The Stille coupling of the cyclohexenone 119 and stannane $\mathbf{2 5}$ produced $\mathbf{1 2 0}$ in excellent yield (89\%). The reductive cyclization of $\mathbf{1 2 0}$ gave carbazolone 1 also in good yield (77\%).

Carbazolone $\mathbf{1}$ is an advanced intermediate in reported syntheses of four different carbazole alkaloids. Not only has this intermediate been used in the synthesis of murrayaquinone A, but also in the preparation of murrayafoline A, murrayanine, and dimeric $O$ - 
demethylmurrayafoline A. Carbazolone $\mathbf{1}$ can be converted to murrayaquinone A through DDQ oxidation in $45 \%$ yield. ${ }^{47}$ In the same synthetic sequence murrayafoline A was prepared via the dehydrogenation of $\mathbf{1}$ followed by methylation (see Scheme 24), and then murrayanine was produced in two steps from murrayafoline A. ${ }^{32}$ Dimeric $O$-demethylmurrayafoline A can also be prepared from this intermediate. 1-Hydroxy-3-methylcarbazole ${ }^{32}$ the dehydrogenation product of carbazolone 1, under oxidative coupling conditions gives the dimeric alkaloid in $87 \%$ yield. $^{31,48}$

\section{Scheme 37}

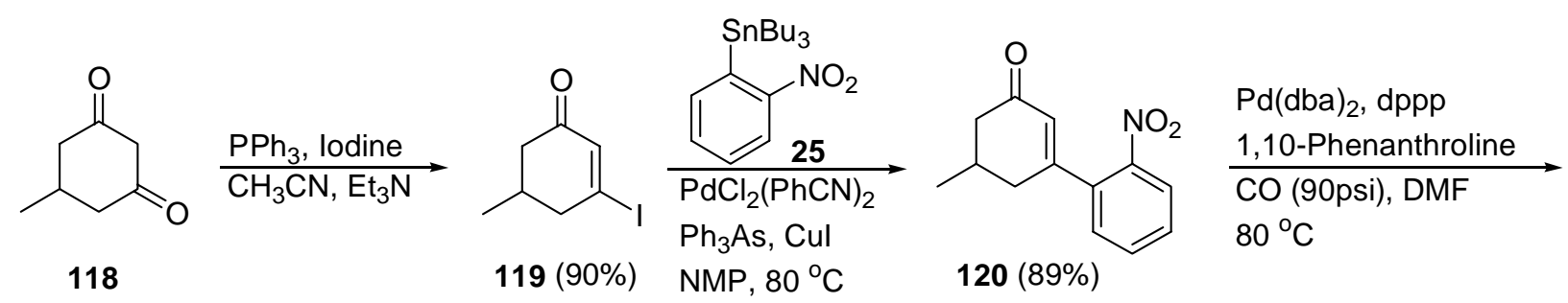<smiles>COc1cc(C=O)cc2c1[nH]c1ccccc12</smiles>

\subsection{Formal Synthesis of Koenigine-quinone A}

The formal synthesis of koenigine-quinone A was carried out in much the same manner as the other syntheses described above. Stannane $\mathbf{1 2 4}$ was first prepared starting from 
aminophenol 121 (Scheme 38). Sandmeyer type reaction of aminophenol 121 produced iodophenol 122 which was methylated to $\mathbf{1 2 3}$. Stannane 124 was prepared from 123 using Kosugi's procedure. ${ }^{17}$ Stille reaction of $\mathbf{1 1 8}$ and $\mathbf{1 2 4}$ under our usual conditions produced $\mathbf{1 2 5}$ in excellent yield (96\%) (Scheme 39). The reductive cyclization also proceeded smoothly giving the key intermediate carbazolone $\mathbf{8 3}$ in $\mathbf{7 9 \%}$. Koenigine-quinone A can be synthesized by the dehydrogenation reaction of carbazolone $\mathbf{8 3}$ followed by oxidation with Fremy's salt as in the synthesis by Saha and Chowdhury. ${ }^{33}$ Their synthesis gives an overall yield for $\mathbf{8 3}$ of $50 \%$ in two steps from 2-hydroxymethylene-5-methylhexanone and 3-methoxyphenyldiazonium chloride while our synthesis produced this intermediate in $76 \%$ yield in two steps.

\section{Scheme 38}

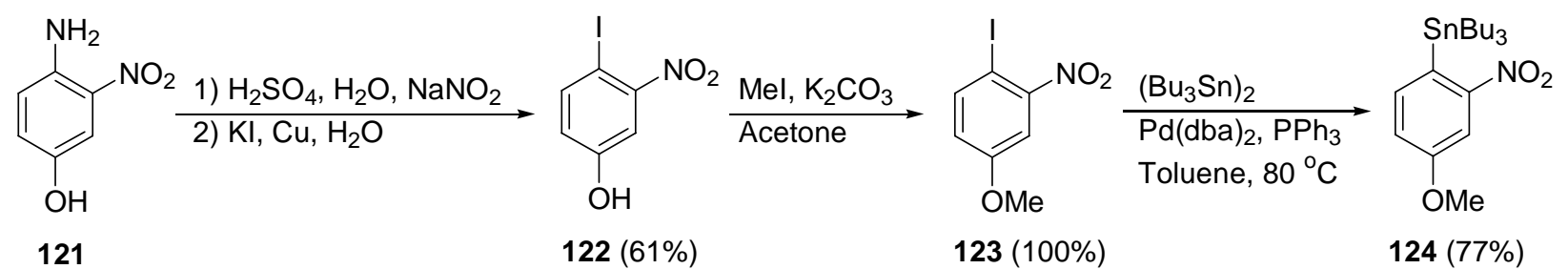

\section{Scheme 39}

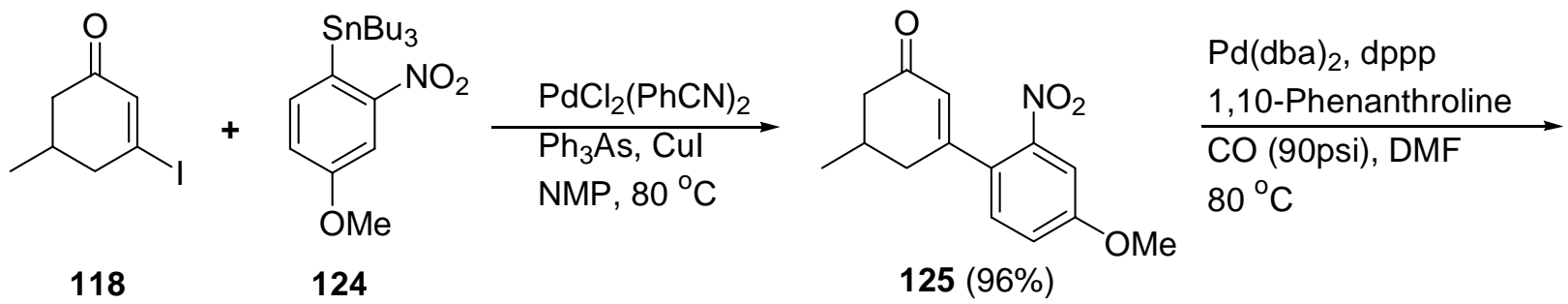

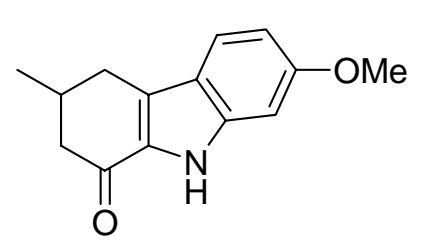

$83(79 \%)$

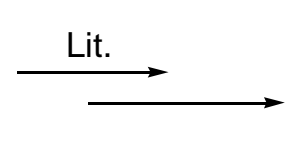




\subsection{Formal Synthesis of (+)-Aspidospermidine}

Desmaele and d'Angelo's synthesis of (+)-aspidospermidine involves the synthesis of the key carbazolone intermediate 112 (Scheme 35). ${ }^{35}$ The synthesis of this intermediate required nine steps from 2-ethylcyclohexanone in $23 \%$ yield. With our new method for making carbazolones we thought we could improve upon the synthesis of this intermediate.

\section{Scheme 40}<smiles>CCC1CCCCC1=O</smiles>

106<smiles>CC[C@H]1CCCCC1=O</smiles>

108 (99\%)

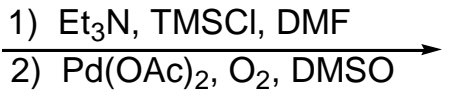<smiles>CC[C@H]1CCC=CC1=O</smiles>

109 (57\%)<smiles>CC[C@]1(CCC(C)=O)CCC=C(I)C1=O</smiles>

$127(86 \%)$<smiles>CCCCc1ccccc1[N+](=O)[O-]</smiles>

$\mathrm{Ph}_{3} \mathrm{As}$, Cul

NMP, $80^{\circ} \mathrm{C}$<smiles>CC[C@H]1CCC=C(c2ccccc2[N+](=O)[O-])C1=O</smiles>

$128(80 \%)$

$\mathrm{Pd}(\mathrm{dba})_{2}, \mathrm{dppp}$

$\underset{\mathrm{CO} \text { (90psi), DMF }}{\stackrel{\text { COPhenanthroline }}{\longrightarrow}}$ $80{ }^{\circ} \mathrm{C}$

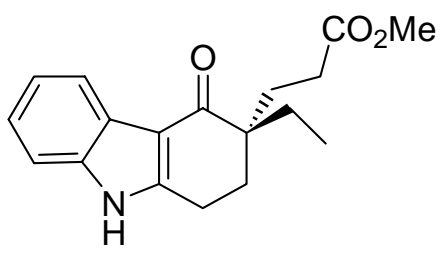

$112(76 \%)$

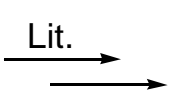

(+) - Aspidospermidine

We prepared cyclohexenone $\mathbf{1 0 9}$ according to the literature procedure from 2ethylcyclohexenone except that we replaced the DDQ oxidation with the palladium-catalyzed 
dehydrosilylation (Scheme 40). In our hands, the DDQ method failed to produce 109. Iodide 127 was prepared using iodine and pyridine in carbon tetrachloride in $86 \%$ yield. The Stille reaction of 127 and 25 with the usual palladium-catalyzed conditions produced 128 in good yield (80\%). Cyclization of $\mathbf{1 2 8}$ proceeded smoothly to carbazolone $\mathbf{1 1 2}$ in $\mathbf{7 6 \%}$ yield.

The synthesis of carbazolone $\mathbf{1 1 2}$ is slightly improved by our method. In only six steps from 2-ethylcyclohexanone we produced this intermediate with an overall yield of $30 \%$.

\section{Conclusions}

We have successfully applied our novel method of preparing carbazolones to the synthesis of several carbazole alkaloids. The formal total syntheses of murrayaquinone A, murrayafoline A, murrayanine, dimeric $O$-demethylmurrayafoline A, koenigine-quinone A, and (+)-aspidospermidine have been achieved using a Stille reaction followed by a palladiumcatalyzed reductive $N$-heteroannulation as the key steps. These new syntheses are generally more efficient and higher yielding than the previous syntheses of these alkaloids. 


\section{Part III}

\section{Synthesis of Carbazole Derivatives via Palladium-Catalyzed Hydrogenation Reactions}

\section{Introduction}

We described a novel route to substituted carbazolones in the previous sections.

Although the mechanistic details of this reaction are unclear it is doubtful that the reaction proceeds through an aniline-type intermediate resulting from reduction of the nitro group. We were curious as to what products might result from the direct reduction of the nitro group in 2-(2nitrophenyl)-2-cyclohexen-1-one (32).

We chose to effect the reduction by a palladium-catalyzed hydrogenation reaction (Scheme 41). Compound 32 in the presence of $10 \% \mathrm{Pd} / \mathrm{C}$ and 1 atm of hydrogen gas in methanol at ambient temperature produced 1,2,3,4-tetrahydrocarbazole (129) in 95\% yield. No additional products were produced in the reaction.

\section{Scheme 41}<smiles>O=C1CCCC=C1c1ccccc1[N+](=O)[O-]</smiles>

32

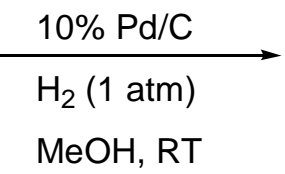

$\mathrm{MeOH}, \mathrm{RT}$<smiles>c1ccc2c3c([nH]c2c1)CCCC3</smiles>

129 (95\%) 
Reduction of compounds related to 32 with $\mathrm{TiCl}_{3}$ have been reported to give $1,2,3,4$ -

tetrahydrocarbazoles. ${ }^{49}$ The reduction of $\mathbf{1 3 0}$ with aqueous $\mathrm{TiCl}_{3}$ in acetone gave $1,2,3,4-$

tetrahydrocarbazole in $88 \%$ yield (Scheme 42). This latter reaction is inherently regioselective.

\section{Scheme 42}<smiles>O=C1CCCCC1c1ccccc1[N+](=O)[O-]</smiles>

130

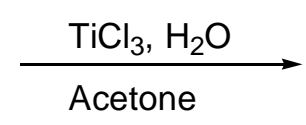

Other common methods to form carbazoles such as the Fischer indole synthesis ${ }^{50}$ and palladium-catalyzed annulations between iodoanilines and ketones ${ }^{51}$ often suffer from the lack of regioselectivity and produce isomers (Scheme 43).

\section{Scheme 43}<smiles>CC1CCCC/C1=N/Nc1ccccc1</smiles>

130<smiles>Nc1ccccc1I</smiles>

132
$\stackrel{\mathrm{H}_{2} \mathrm{SO}_{4}, \mathrm{MeOH}, 80^{\circ} \mathrm{C}}{\longrightarrow}$<smiles>CC1CCCC(=O)C1</smiles>

133
$\stackrel{\mathrm{Pd}(\mathrm{OAc})_{2}, \mathrm{DMF}}{\longrightarrow}$<smiles>CC1CCCc2[nH]c3ccccc3c21</smiles>

$134(8 \%)$<smiles>CC12CCCCC1=Nc1ccccc12</smiles>

132<smiles>CC1CCc2c([nH]c3ccccc23)C1</smiles>

$135(65 \%)$ 
To the best of our knowledge there is only one example in the literature of a reductive cyclization involving a nitrobenzene and an $\alpha, \beta$-unsaturated ketone moiety. The reduction of 2 (2-nitrophenyl)propenal using $\mathrm{PtO}_{2}$ and hydrogen (1 atm) in methanol was reported to produce 3-methylindole in $40 \%$ yield (Scheme 44$){ }^{52}$

\section{Scheme 44}

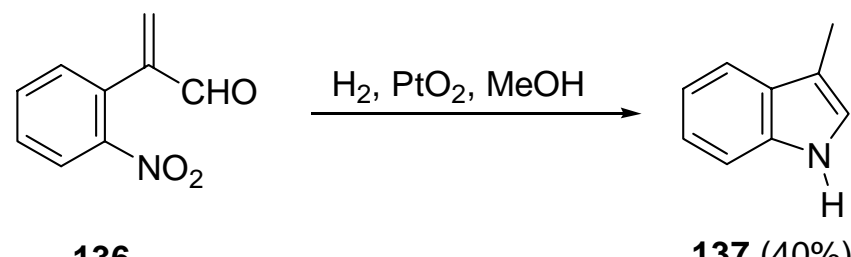

We envisioned the reductive cyclization of compounds such as $\mathbf{3 2}$ using simple hydrogenation procedures to be potentially promising for the synthesis of carbazole derivatives. We have investigated the scope and limitations of this reaction using several examples.

\section{Results and Discussion}

We had previously prepared a number of substituted 2-(2-nitrophenyl)-2-cycloalkenones for the synthesis of carbazolones as described in Part I and II. Additional substrates were made according to similar procedures. Compound 142 was synthesized starting from 4methylcyclohexanone (138) (Scheme 45). The silyl enol ether 139 was prepared, followed by palladium-catalyzed dehydrosilylation ${ }^{20}$ to give 4-methyl-2-cyclohexen-1-one (140). The low yield of the dehydrosilylation reaction may be contributed to the volatility of the product. Iodide 141 was prepared according to Johnson's procedure ${ }^{18}$ using iodine and pyridine in carbon tetrachloride in $65 \%$ yield. The Stille reaction of 141 and stannane 25 using $\mathrm{PdCl}_{2}(\mathrm{PhCN})_{2}$, 
$\mathrm{Ph}_{3} \mathrm{As}$, and $\mathrm{CuI}$ in NMP gave 142 in good yield (80\%). Compound 144 was prepared similarly from the Stille coupling of 2-iodo-3-methylcyclohexenone ${ }^{18}(\mathbf{1 4 3})$ and 25 in $78 \%$ yield (Scheme 46).

\section{Scheme 45}
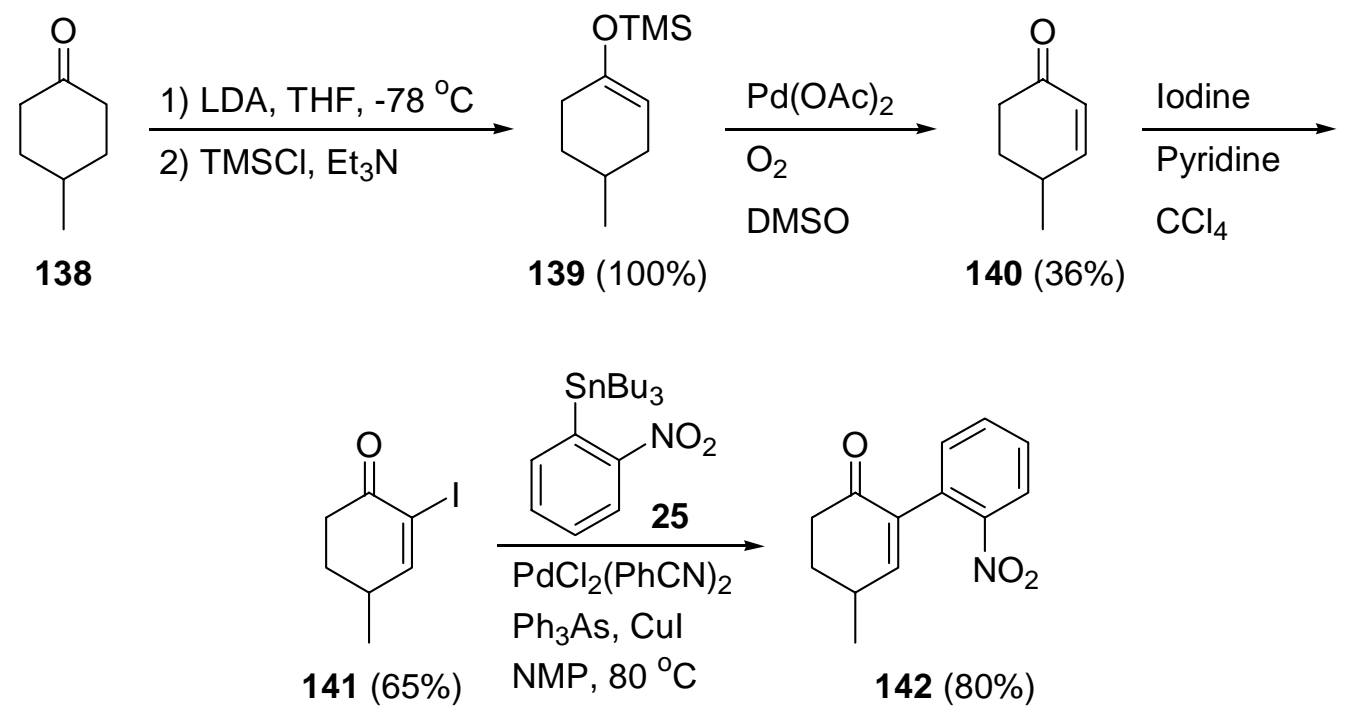

\section{Scheme 46}

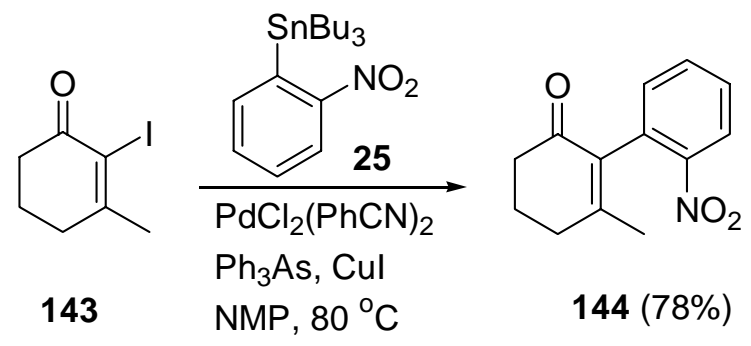

The results of the reductive cyclizations are summarized in Table 3. The reductions were carried out using $10 \% \mathrm{Pd} / \mathrm{C}(\sim 20 \mathrm{~mol} \% \mathrm{Pd})$ and hydrogen gas (1 atm, balloon) in methanol at room temperature. Most of the reactions were complete in 20 minutes to 2 hours as monitored by thin layer chromatography. Some of the compounds appeared to be acid-sensitive, so for 
these compounds additional handling precautions were taken such as using base-washed glassware, filtering NMR solvents through potassium carbonate prior to use, and using a small amount of triethylamine in the chromatography solvents.

Excellent yields of methyl-substituted carbazoles were obtained from the reductions of substrates $\mathbf{1 1 5}, \mathbf{3 3}, \mathbf{1 4 2}$, and $\mathbf{1 4 4}$. These reactions were very regioselective producing only one product per substrate without the formation of other isomers.

Investigation of ring-size in the reductive cyclization reaction gave a different result. Cycloheptenone 35 gave the expected product 5,6,7,8,9,10-hexahydrocyclohepta[d]indole (147). However, cyclopentenone 34 produced the unexpected product 146.

Substitution on the benzene ring greatly affected the types of products produced. Not only were tetrahydrocarbazole products produced but tetrahydrocarbazolones and hexahydrocarbazoles as well. There appears to be no correlation between the electron donating or withdrawing nature of substituents and the type of products produced. Two products were isolated for the reaction of each substrate $\mathbf{3 7}, \mathbf{3 9}$, and $\mathbf{4 0 .}$

Substrate $\mathbf{7 0}$ also gave a surprising result. The reductive cyclization of this compound not only produced the expected carbazolone 5, but 1,2,3,4-tetrahydrocarbazole (129) as well. In order to determine what was happening in this reaction, carbazolone $\mathbf{5}$ was subjected to the hydrogenation conditions (Scheme 47). Carbazolone 5 did yield some tetrahydrocarbazole 129, but $39 \%$ of the starting material was still present even after 3 days. 


\section{Table 3}

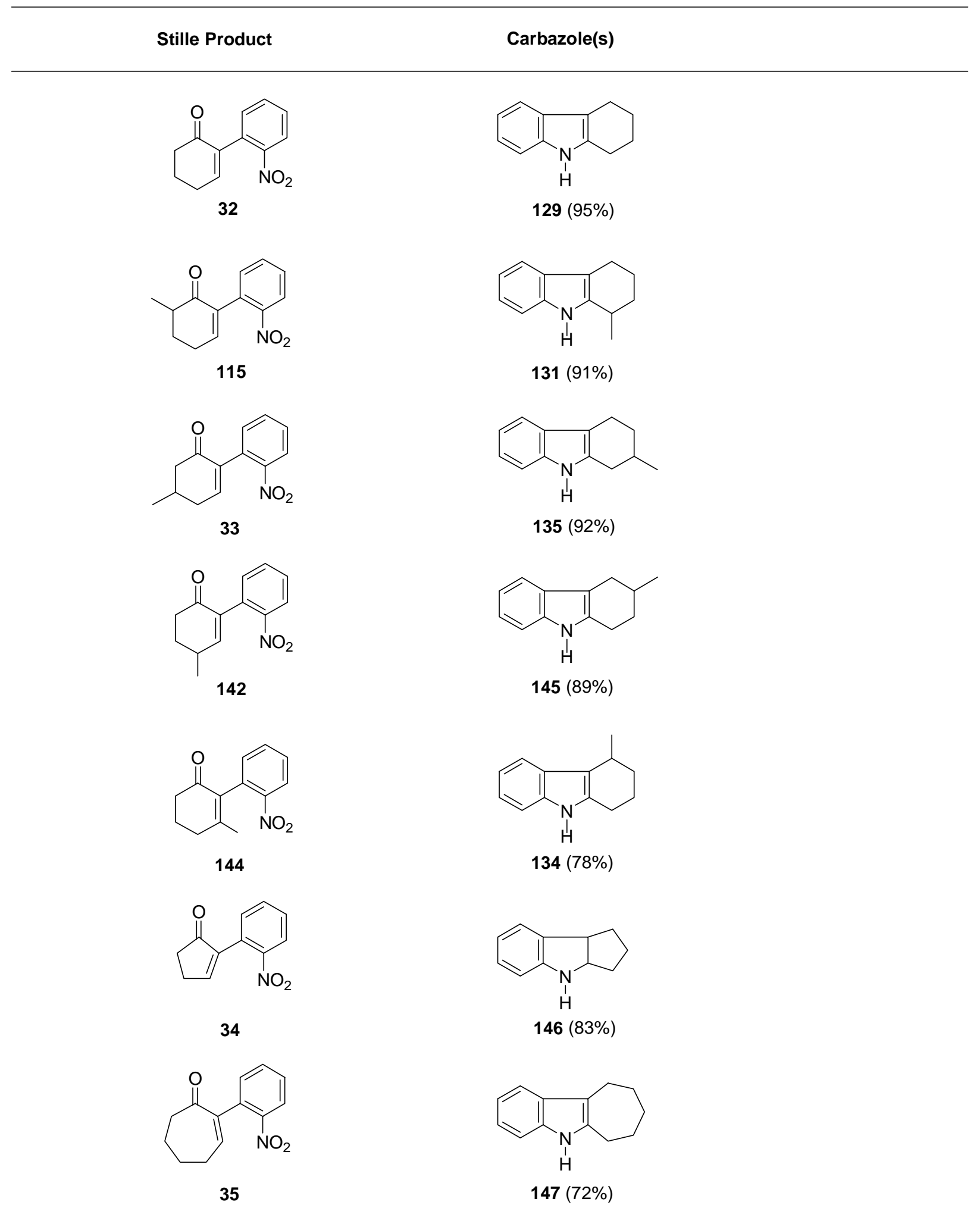


Table 3 continued

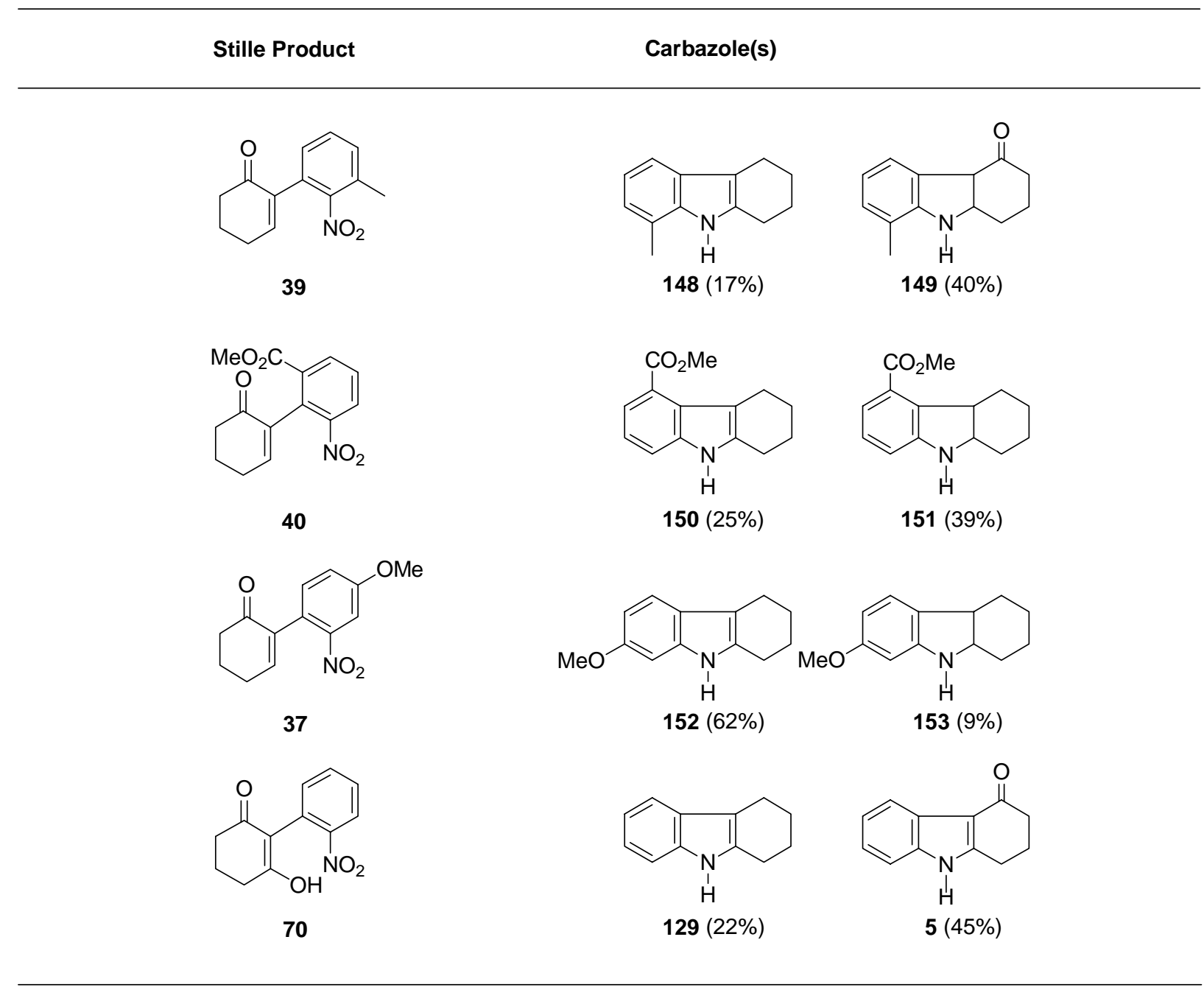

General conditions: $10 \% \mathrm{Pd} / \mathrm{C}$ ( 20 mol\% Pd), hydrogen gas (1 atm, balloon), MeOH, RT. For more exact details see: Experimental Section.

\section{Scheme 47}<smiles>O=C1CCCc2[nH]c3ccccc3c21</smiles>

5

$$
\begin{aligned}
& \underset{\mathrm{Pd} / \mathrm{C}(20 \mathrm{~mol} \% \mathrm{Pd})}{\mathrm{H}_{2}(1 \mathrm{~atm})} \\
& \mathrm{MeOH}, 3 \text { days }
\end{aligned}
$$<smiles>O=C1CCCc2[nH]c3ccccc3c21</smiles>

5 (39\% recovered)<smiles>c1ccc2c3c([nH]c2c1)CCCC3</smiles>

129 (35\%) 
We also investigated the effect of the amount of palladium in this reaction (Scheme 48).

Substrate 39 gave only 149 in quantitative yield when the amount of palladium was decreased to $2 \mathrm{~mol} \%$. This result leads us to believe that the product distribution in other reactions can be controlled by adjusting the amount of palladium used. The reductive cyclizations of other substrates have yet to be performed with reduced amounts of catalyst.

\section{Scheme 48}

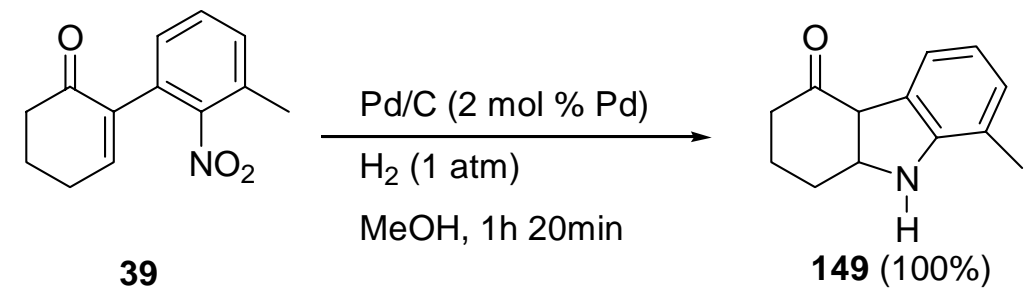

Scheme 49 shows the possible intermediates in this reaction. Reduction of the nitro group produces an amine intermediate 154 which can react in either a 1,2- or a 1,4-addition fashion with the enone. The 1,2-addition pathway can give compound $\mathbf{1 5 5}$ which leads to tetrahydrocarbazole 129 by direct reduction and isomerization or through intermediate 156 with subsequent reduction. A hexahydrocarbazole product can be formed from many different intermediates. Reduction of intermediates $\mathbf{1 5 5}$ and 156, as well as the tetrahydrocarbazole product 129, could all yield a hexahydrocarbazole. Although the latter pathway is the least likely due to the aromaticity of the the tetrahydrocarbazole 129. Tetrahydrocarbazolone $\mathbf{1 5 9}$ can be produced through a 1,4-addition of amine 154 to the enone, followed by tautomerization of enol 158. 


\section{Scheme 49}

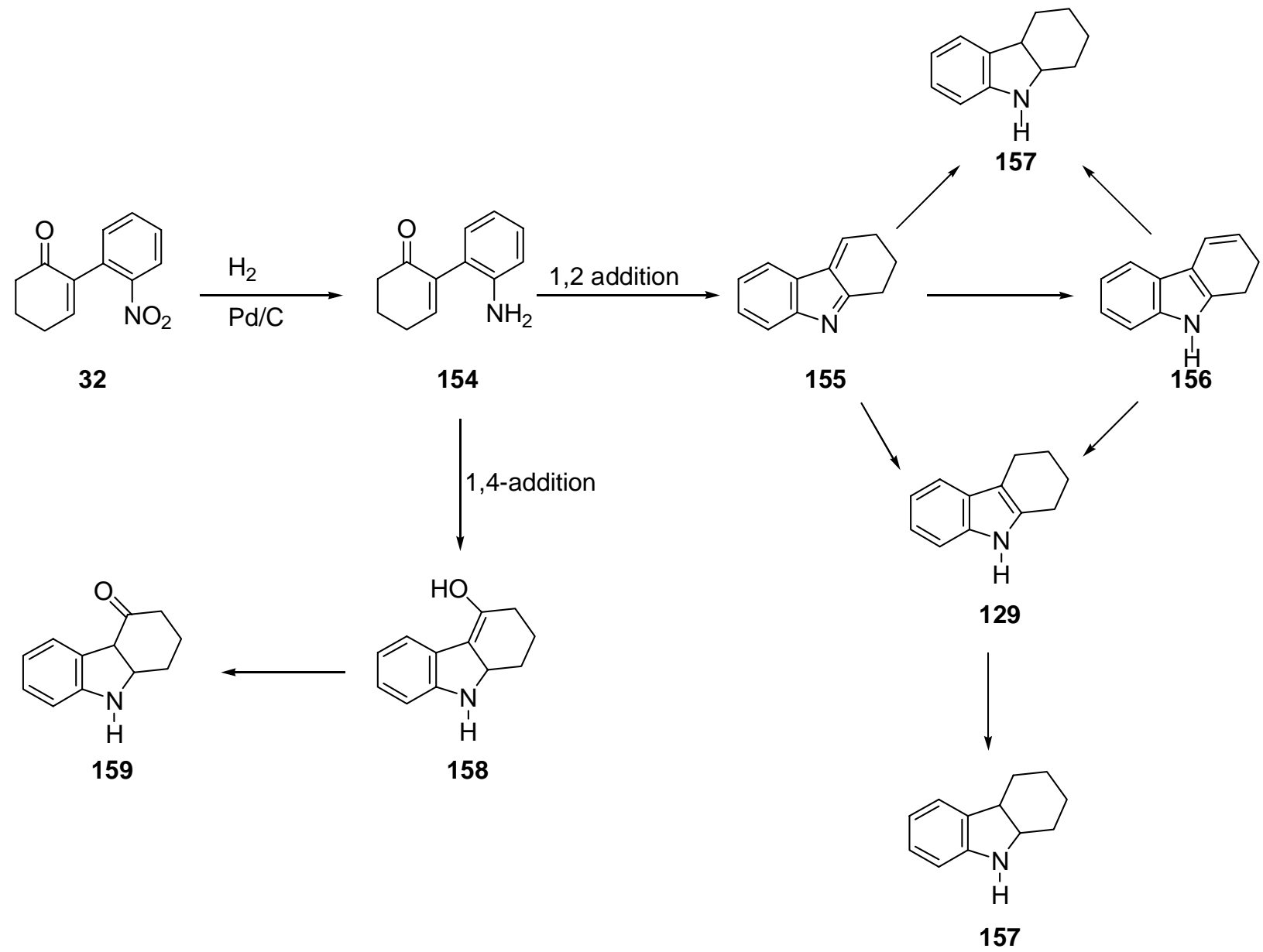

\section{Conclusions}

We have developed a mild and efficient route to carbazole derivatives through two consecutive palladium-catalyzed reactions, a Stille coupling followed by a reductive cyclization reaction. Unsubstituted 2-cyclohexenone and methyl-substituted cyclohexenone starting materials give the corresponding 1,2,3,4-tetrahydrocarbazole products exclusively in excellent yields. Substitution on the benzene ring leads to mixtures of 1,2,3,4-tetrahydrocarbazoles, 1,2,4a,9a-tetrahydro-4(3H)carbazolones, and 1,2,3,4,4a,9a-hexahydrocarbazoles. The cycloheptenone 35 underwent the reductive cyclization to give the expected 5,6,7,8,9,10- 
hexahydrocyclohepta $[d]$ indole, whereas the cyclopentenone $\mathbf{3 4}$ resulted in 1,2,3,3a,4,8bhexahydrocyclopenta[$[b]$ indole. As of now, there are no explanations for the types and mixtures of products in some of these reactions. However, the method does seem to be excellent for selectively producing methyl-substituted carbazoles which can be difficult by other means. Further studies of the regiochemistry and mechanism of the reductive cyclization are currently underway. 


\section{Part IV}

\section{Experimental Section}

\section{General Procedures}

All NMR spectra were determined in $\mathrm{CDCl}_{3}$ at $270 \mathrm{MHz}\left({ }^{1} \mathrm{H} \mathrm{NMR}\right)$ and $67.5 \mathrm{MHz}\left({ }^{13} \mathrm{C}\right.$ NMR). The chemical shifts are expressed in $\delta$ values relative to $\mathrm{Me}_{4} \mathrm{Si}\left(0.00,{ }^{1} \mathrm{H}\right.$ and $\left.{ }^{13} \mathrm{C}\right)$ or $\mathrm{CDCl}_{3}\left(7.26,{ }^{1} \mathrm{H}\right.$ and $\left.77.00,{ }^{13} \mathrm{C}\right)$ internal standards. ${ }^{1} \mathrm{H}-{ }^{1} \mathrm{H}$ coupling constants are reported as calculated from spectra; thus, a slight difference between $J_{\mathrm{a}, \mathrm{b}}$ and $J_{\mathrm{b}, \mathrm{a}}$ is usually obtained. Results of APT (attached proton test) ${ }^{13} \mathrm{C}$ NMR experiments are shown in parentheses, where relative to $\mathrm{CDCl}_{3}$, (-) denotes $\mathrm{CH}_{3}$ or $\mathrm{CH}$ and (+) denotes $\mathrm{CH}_{2}$ or $\mathrm{C}$.

Tetrahydrofuran (THF), toluene, and diethyl ether were distilled from sodium benzophenone ketyl prior to use. Pyridine, triethylamine, hexanes, acetonitrile, diisopropylamine, and ethyl acetate were distilled from calcium hydride. Chemicals prepared according to literature procedures have been footnoted the first time they are used; all other reagents were obtained from commercial sources and used as received. Silica gel (200-400 mesh) was used for flash chromatography. All reactions were performed in oven-dried glassware under an argon atmosphere unless otherwise noted. Solvents were removed on a rotary evaporator at water aspirator pressure unless otherwise stated. IR spectra were recorded on neat compounds using $\mathrm{NaCl}$ plates unless otherwise noted. Elemental analyses were performed by Atlantic Microlab, Inc., Norcross, GA. High Resolution Mass Spectra (HRMS) were performed at University of California Riverside Mass Spectrometry Center. 


\section{Experimental Details}

\section{2-Iodo-5-methyl-2-cyclohexen-1-one (20).}

To a solution of 5-methyl-2-cyclohexen-1-one ${ }^{19}$ (47) $(502 \mathrm{mg}, 4.55 \mathrm{mmol})$ in $20 \mathrm{~mL}$ of 1:1 $\mathrm{CCl}_{4} /$ pyridine cooled to $0{ }^{\circ} \mathrm{C}$ was added dropwise a solution of iodine $(2.30 \mathrm{~g}, 9.04 \mathrm{mmol})$ dissolved in $20 \mathrm{~mL}$ of $1: 1 \mathrm{CCl}_{4} /$ pyridine with stirring. The reaction mixture was allowed to warm to ambient temperature overnight. The reaction mixture was diluted with ether $(100 \mathrm{~mL})$ and washed successively with water $(40 \mathrm{~mL}), \mathrm{HCl}(5 \%$, aq, 2 x $40 \mathrm{~mL})$, water $(40 \mathrm{~mL})$, and $\mathrm{Na}_{2} \mathrm{~S}_{2} \mathrm{O}_{3}(20 \%$, aq, $40 \mathrm{~mL})$. The organic phase was dried $\left(\mathrm{MgSO}_{4}\right)$ and concentrated under vacuum. The crude product was purified by flash chromatography (hexanes/EtOAc, 9:1) to give 20 (911 mg, $3.86 \mathrm{mmol}, 85 \%$ ) as a light yellow solid: $\mathrm{mp} 39-40{ }^{\circ} \mathrm{C}$; IR 2955, 1682, $1590 \mathrm{~cm}^{-1}$; ${ }^{1} \mathrm{H}$ NMR $\delta 1.08(\mathrm{~d}, J=5.9 \mathrm{~Hz}, 3 \mathrm{H}), 2.11-2.53(\mathrm{~m}, 4 \mathrm{H}), 2.69-2.83(\mathrm{~m}, 1 \mathrm{H}), 7.72(\mathrm{dd}, J=5.9$ and $2.9 \mathrm{~Hz}, 1 \mathrm{H}) ;{ }^{13} \mathrm{C}$ NMR $\delta . ~ 20.6(-), 30.4(-), 37.9(+), 45.0(+), 103.5(+), 158.6(-), 192.5(+)$; HRMS (EI) calcd for $\mathrm{C}_{7} \mathrm{H}_{9} \mathrm{IO}\left(\mathrm{M}^{+}\right)$235.9698, found 235.9703.

\section{2-Iodo-2-cyclohepten-1-one $\mathrm{s}^{53}$ (22).}

To a solution of 2-cyclohepten-1-one (535 mg, $4.86 \mathrm{mmol}$ ) in $20 \mathrm{~mL}$ of $1: 1 \mathrm{CCl}_{4} /$ pyridine cooled to $0{ }^{\circ} \mathrm{C}$ was added dropwise a solution of iodine $(2.71 \mathrm{~g}, 10.7 \mathrm{mmol})$ dissolved in $20 \mathrm{~mL}$ of $1: 1 \mathrm{CCl}_{4} /$ pyridine with stirring. The reaction mixture was allowed to warm to ambient temperature overnight. The reaction mixture was diluted with ether $(100 \mathrm{~mL})$ and washed successively with water $(40 \mathrm{~mL}), \mathrm{HCl}(5 \%$, aq, $2 \times 40 \mathrm{~mL})$, water $(40 \mathrm{~mL})$, and $\mathrm{Na}_{2} \mathrm{~S}_{2} \mathrm{O}_{3}(20 \%$, aq, $40 \mathrm{~mL})$. The organic phase was dried $\left(\mathrm{MgSO}_{4}\right)$ and concentrated under vacuum. The crude 
product was purified by flash chromatography (hexanes/EtOAc, 9:1) to give 22 (786 mg, 3.33 mmol, 69\%) as a light yellow solid.

\section{2-(tri-n-Butylstannyl)-2-cyclohexen-1-one ${ }^{54}(24)$.}

tert-Butyllithium (34.5 $\mathrm{mL}$ of a $1.7 \mathrm{M}$ solution in hexanes, $58.7 \mathrm{mmol}$ ) was added dropwise to a solution of 6-bromo-1,4-dioxaspiro[4,5]dec-6-ene ${ }^{55}$ (46) $(6.00 \mathrm{~g}, 27.4 \mathrm{mmol})$ in diethyl ether $(480 \mathrm{~mL})$ cooled to $-78{ }^{\circ} \mathrm{C}$. After $30 \mathrm{~min}$, tributyltinchloride $(8.2 \mathrm{~mL}, 30.2 \mathrm{mmol})$ was added slowly, and the reaction mixture stirred another $30 \mathrm{~min}$ at $-78{ }^{\circ} \mathrm{C}$. The reaction mixture was allowed to warm to room temperature, and $\mathrm{HCl}(10 \%$, aq, 200mL) was added slowly. The reaction mixture was stirred for $3 \mathrm{~h}$. After dilution with diethyl ether $(500 \mathrm{~mL})$, the reaction mixture was washed successively with water $(500 \mathrm{~mL}), \mathrm{NH}_{4} \mathrm{OH}(10 \%$, aq, $500 \mathrm{~mL})$, and water $(500 \mathrm{~mL})$. The organic phase was dried $\left(\mathrm{MgSO}_{4}\right)$ and concentrated. The crude product was purified by flash chromatography (hexanes/EtOAc, 95:5) to give $\mathbf{2 4}(8.38 \mathrm{~g}, 21.8 \mathrm{mmol}$, $79 \%$ ) as a clear, colorless oil.

\section{3-Iodo-2-nitrotoluene ${ }^{56}(29)$.}

To a mixture of 3-methyl-2-nitroaniline $(502 \mathrm{mg}, 3.30 \mathrm{mmol})$, ice, water $(4 \mathrm{~mL})$, and $\mathrm{H}_{2} \mathrm{SO}_{4}$ (conc., $0.2 \mathrm{~mL}$ ) cooled in an ice bath was added a solution of $\mathrm{NaNO}_{2}(251 \mathrm{mg}, 3.64$ $\mathrm{mmol})$ in water $(1 \mathrm{~mL})$ very slowly $(\sim 1 \mathrm{drop} / \mathrm{min})$. After the addition, the reaction mixture was stirred $20 \mathrm{~min}$ and additional $\mathrm{H}_{2} \mathrm{SO}_{4}$ (conc., $\sim 0.07 \mathrm{~mL}$ ) was added. The reaction mixture was poured slowly into an ice-cold solution of KI $(656 \mathrm{mg}, 3.95 \mathrm{~mL})$ in water $(1 \mathrm{~mL})$. After a few minutes $\mathrm{Cu}$ powder ( $4 \mathrm{mg}, 0.06 \mathrm{mmol}$ ) was added, and the reaction mixture was warmed slowly to $80{ }^{\circ} \mathrm{C}$ for about $30 \mathrm{~min}$. The reaction mixture was allowed to cool, was extracted with $\mathrm{CH}_{2} \mathrm{Cl}_{2}$ 
(3 x $50 \mathrm{~mL}$ ), washed with $\mathrm{Na}_{2} \mathrm{~S}_{2} \mathrm{O}_{3}(20 \%$, aq, $50 \mathrm{~mL})$, dried $\left(\mathrm{MgSO}_{4}\right)$, and concentrated under vacuum. The crude product was purified by flash chromatography (hexanes/EtOAc, 8:2) to give 29 (764 $\mathrm{mg}, 2.90 \mathrm{mmol}, 88 \%)$ as a yellow-orange solid.

\section{4-Bromo-2-iodo-1-nitrobenzene (31).}

To a mixture of 5-bromo-2-nitroaniline ${ }^{57}(\mathbf{5 4})(198 \mathrm{mg}, 0.910 \mathrm{mmol})$, ice, water $(5 \mathrm{~mL})$, and $\mathrm{H}_{2} \mathrm{SO}_{4}$ (conc., $0.2 \mathrm{~mL}$ ) cooled to $0{ }^{\circ} \mathrm{C}$ was added a solution of $\mathrm{NaNO}_{2}(70.2 \mathrm{mg}, 1.02 \mathrm{~mL}$ ) very slowly ( $\sim 1 \mathrm{drop} / \mathrm{min})$. The reaction mixture was stirred for $1.5 \mathrm{~h}$ at room temperature, and then was added very slowly to an ice-cold solution of KI (190 mg, $1.14 \mathrm{mmol})$ in water (1 mL). After a few min $\mathrm{Cu}$ powder $(2 \mathrm{mg}, 0.03 \mathrm{mmol})$ was added, and the reaction mixture was heated slowly to $80{ }^{\circ} \mathrm{C}$ for $20 \mathrm{~min}$. The reaction mixture was allowed to cool, was extracted with $\mathrm{CH}_{2} \mathrm{Cl}_{2}(3 \times 50 \mathrm{~mL})$, washed with $\mathrm{Na}_{2} \mathrm{~S}_{2} \mathrm{O}_{3}(10 \%$, aq, $50 \mathrm{~mL})$, dried $\left(\mathrm{MgSO}_{4}\right)$, and concentrated under vacuum. The crude product was purified by flash chromatography (hexanes/EtOAc, 9:1) to give 31 (182 mg, $0.55 \mathrm{mmol}, 61 \%)$ as a yellow solid: $\mathrm{mp} 77-79{ }^{\circ} \mathrm{C}$; IR $1563,1518,1335 \mathrm{~cm}^{-1}$; ${ }^{1} \mathrm{H}$ NMR $\delta(\mathrm{dd}, J=8.5$ and $2.0 \mathrm{~Hz}, 1 \mathrm{H}), 7.77(\mathrm{~d}, J=8.5 \mathrm{~Hz}, 1 \mathrm{H}), 8.22(\mathrm{~d}, \mathrm{~J}=2.0 \mathrm{~Hz}, 1 \mathrm{H}) ;{ }^{13} \mathrm{C}$ NMR $\delta 87.4(+), 126.4(-), 127.7(+), 132.2(-), 144.1(-), 151.7(+)$.

\section{2-(2-Nitrophenyl)-2-cyclohexen-1-one $\mathrm{e}^{23}(32)$.}

To a solution of 2-iodo-2-cyclohexen-1-one (19) ${ }^{18}(808 \mathrm{mg}, 3.64 \mathrm{mmol})$ and 2-(tri- $n$ butylstannyl)-1-nitrobenzene $(\mathbf{2 5})^{17}(1.80 \mathrm{~g}, 4.34 \mathrm{mmol})$ in $N$-methylpyrrolidinone (NMP) (4 $\mathrm{mL}$ ) was added $\mathrm{PdCl}_{2}(\mathrm{PhCN})_{2}(77.5 \mathrm{mg}, 0.20 \mathrm{mmol}), \mathrm{Ph}_{3} \mathrm{As}(117 \mathrm{mg}, 0.40 \mathrm{mmol})$, and $\mathrm{CuI}$ (77.2 $\mathrm{mg}, 0.40 \mathrm{mmol})$. The reaction mixture was heated at $80{ }^{\circ} \mathrm{C}$ for $20 \mathrm{~h}$. The reaction mixture was diluted with EtOAc $(100 \mathrm{~mL})$ and washed successively with $\mathrm{NH}_{4} \mathrm{OH}(10 \%$, aq, 3 X $30 \mathrm{~mL})$ 
and $\mathrm{H}_{2} \mathrm{O}(2 \mathrm{X} 30 \mathrm{~mL})$. The aqueous portions were extracted with EtOAc $(50 \mathrm{~mL})$. The organic phases were combined, dried $\left(\mathrm{MgSO}_{4}\right)$, and concentrated. The crude product was purified by flash chromatography (hexanes/EtOAc, 9:1) to give 32 (603 mg, $2.77 \mathrm{mmol}, 76 \%)$ as a light yellow solid.

Alternate procedure: Compound 32 was also prepared repeating the above procedure except using 2-(tri-n-butylstannyl)-2-cyclohexenone (24) (931 mg, 2.42 mmol), 1-iodo-2nitrobenzene (26) (502 mg, $2.01 \mathrm{mmol}), \mathrm{PdCl}_{2}(\mathrm{PhCN})_{2}(38.5 \mathrm{mg}, 0.10 \mathrm{mmol}), \mathrm{Ph}_{3} \mathrm{As}(70.1 \mathrm{mg}$, $0.22 \mathrm{mmol}$ ), $\mathrm{CuI}$ (41.9 mg, $0.22 \mathrm{mmol})$, and NMP (4 mL) to give 32 (309 $\mathrm{mg}, 1.42 \mathrm{mmol}, 71 \%$ ).

\section{5-Methyl-2-(2-nitrophenyl)-2-cyclohexen-1-one (33).}

The same procedure as described for 32 was repeated except that a mixture of 2-iodo-5methyl-2-cyclohexen-1-one (20) (241 mg, $1.02 \mathrm{mmol}), 1$-(tri- $n$-butylstannyl)-2-nitrobenzene (25) (455 mg, $1.10 \mathrm{mmol}), \mathrm{PdCl}_{2}(\mathrm{PhCN})_{2}(20.6 \mathrm{mg}, 0.05 \mathrm{mmol}), \mathrm{Ph}_{3} \mathrm{As}(31.6 \mathrm{mg}, 0.10 \mathrm{mmol})$, $\mathrm{CuI}(19.1 \mathrm{mg}, 0.10 \mathrm{mmol})$, and NMP (1 mL) gave 33 (175 mg, $0.75 \mathrm{mmol}, 74 \%)$ as a pale yellow solid: $\operatorname{mp~107-109~}{ }^{\circ} \mathrm{C}$; IR 1672, 1517, $1340 \mathrm{~cm}^{-1} ;{ }^{1} \mathrm{H}$ NMR $\delta 1.03(\mathrm{~d}, J=8.1 \mathrm{~Hz}, 3 \mathrm{H})$, 2.10-2.35 (m, 3H), 2.44-2.59 (m, 2H), $6.90(\mathrm{dd}, J=5.5$ and $2.8 \mathrm{~Hz}, 1 \mathrm{H}), 7.16(\mathrm{dd}, J=7.5$ and $1.6 \mathrm{~Hz}, 1 \mathrm{H}), 7.35(\mathrm{td}, J=6.4$ and $1.6 \mathrm{~Hz}, 1 \mathrm{H}), 7.49(\mathrm{td}, J=7.3$ and $1.2 \mathrm{~Hz}, 1 \mathrm{H}), 7.88(\mathrm{dd}, J=8.1$ and 1.2, 1H); ${ }^{13} \mathrm{C}$ NMR $\delta 20.9(-), 29.9(-), 34.3(+), 46.1(+), 123.9(-), 128.6(-), 131.5(-)$, $131.7(+), 133.2(-), 138.8(+), 146.0(-), 148.4(+), 196.5(+) ;$ HRMS (DEI) calcd for $\mathrm{C}_{13} \mathrm{H}_{13} \mathrm{NO}_{3}$ $\left(\mathrm{MH}^{+}\right)$232.0974, found 232.0965. 


\section{2-(2-Nitrophenyl)-2-cyclopenten-1-one (34).}

The same procedure as described for 32 was repeated except that a mixture of 2-iodo-2cyclopenten-1-one $(\mathbf{2 1})^{18}$ (290 mg, $\left.1.40 \mathrm{mmol}\right), 1$-(tri- $n$-butylstannyl)-2-nitrobenzene (25) (643 mg, $1.56 \mathrm{mmol}), \mathrm{PdCl}_{2}(\mathrm{PhCN})_{2}(26.7 \mathrm{mg}, 0.07 \mathrm{mmol}), \mathrm{Ph}_{3} \mathrm{As}$ (43.7 mg, $\left.0.14 \mathrm{mmol}\right), \mathrm{CuI}(29.2$ $\mathrm{mg}, 0.15 \mathrm{mmol})$, and NMP (2.8 $\mathrm{mL})$ gave $34(183 \mathrm{mg}, 0.90 \mathrm{mmol}, 65 \%)$ as a pale yellow solid: mp 94.5-96.5 ${ }^{\circ} \mathrm{C}$; IR 1697, 1518, $1349 \mathrm{~cm}^{-1} ;{ }^{1} \mathrm{H}$ NMR $\delta .2 .56-2.60$ (m, 2H), 2.78-2.83 (m, 2H), $7.32(\mathrm{dd}, J=7.5$ and $1.6 \mathrm{~Hz}, 1 \mathrm{H}), 7.49(\mathrm{td}, J=7.5$ and $1.4 \mathrm{~Hz}, 1 \mathrm{H}), 7.61(\mathrm{td}, J=7.5$ and $1.4 \mathrm{~Hz}$, 1H), $7.69(\mathrm{t}, J=2.8 \mathrm{~Hz}, 1 \mathrm{H}), 8.02(\mathrm{dd}, J=8.1$ and $2.6 \mathrm{~Hz}, 1 \mathrm{H}) ;{ }^{13} \mathrm{C} \mathrm{NMR} \delta 27.0(+), 34.5(+)$, $124.3(-), 127.1(+), 129.1(-), 131.2(-), 133.0(-), 143.7(+), 148.2(+), 159.0(-), 205.3(+)$; Anal. Calcd for $\mathrm{C}_{11} \mathrm{H}_{9} \mathrm{NO}_{3}$ : C, 65.02; H, 4.46. Found: C, 65.15; H, 4.46.

\section{2-(2-Nitrophenyl)-2-cyclohepten-1-one (35).}

The procedure as described for 32 was repeated except that a mixture of 2-iodo-2cyclohepten-1-one (22) (389 mg, 1.65 mmol), 1-(tri- $n$-butylstannyl)-2-nitrobenzene (25) (820 mg, $1.99 \mathrm{mmol}), \mathrm{PdCl}_{2}(\mathrm{PhCN})_{2}(31.9 \mathrm{mg}, 0.08 \mathrm{mmol}), \mathrm{Ph}_{3} \mathrm{As}$ (51.7 mg, $\left.0.16 \mathrm{mmol}\right), \mathrm{CuI}(31.2$ mg, $0.16 \mathrm{mmol})$, and NMP (1.6 mL) gave after purification by flash chromatography (benzene/ $\left.\mathrm{CH}_{2} \mathrm{Cl}_{2}, 95: 5\right) 35$ (259 mg, $1.12 \mathrm{mmol}, 68 \%$ ) as a pale yellow sold: $\mathrm{mp} 83-85{ }^{\circ} \mathrm{C}$; IR 1665, 1517, $1340 \mathrm{~cm}^{-1} ;{ }^{1} \mathrm{H}$ NMR $\delta$ 1.81-1.99 (m, 4H), 2.53-2.61 (m, 2H), 2.74-2.80 (m, 2H), $6.74(\mathrm{t}, J=6.5 \mathrm{~Hz}, 1 \mathrm{H}), 7.28(\mathrm{dd}, J=7.5$ and $1.6 \mathrm{~Hz}, 1 \mathrm{H}), 7.43(\mathrm{td}, J=8.1$ and $1.6 \mathrm{~Hz}, 1 \mathrm{H}), 7.58$

$(\mathrm{td}, J=7.5$ and $1.6 \mathrm{~Hz}, 1 \mathrm{H}) 8.00(\mathrm{dd}, J=8.1$ and $1.2 \mathrm{~Hz}, 1 \mathrm{H}) ;{ }^{13} \mathrm{C} \mathrm{NMR} \delta 21.0(+), 25.0(+)$, $27.8(+), 42.4(+), 124.2(-), 128.5(-), 132.6(-), 133.5(-), 135.1(+), 142.9(+), 143.1(-), 147.2$ (+), $202.5(+)$; HRMS (EI) calcd for $\mathrm{C}_{13} \mathrm{H}_{13} \mathrm{NO}_{3}\left(\mathrm{M}^{+}\right)$231.0895, found 231.0895. 


\section{8,9-Dihydro-5H-6-(2-nitrophenyl)-benzocyclohepten-5-one (36).}

The same procedure as described for 32 was repeated except that a mixture of 6-bromo8,9-dihydro-5H-benzocyclohepten-5-one $(\mathbf{2 3})^{21}$ (250 mg, $\left.1.06 \mathrm{mmol}\right)$, 1-(tri- $n$-butylstannyl)-2nitrobenzene (25) (496 mg, $1.20 \mathrm{mmol}), \mathrm{PdCl}_{2}(\mathrm{PhCN})_{2}(21.5 \mathrm{mg}, 0.06 \mathrm{mmol}), \mathrm{Ph}_{3} \mathrm{As}(34.1 \mathrm{mg}$, $0.11 \mathrm{mmol})$, CuI (21.0 mg, $0.11 \mathrm{mmol})$, and NMP (1 mL) after $40 \mathrm{~h}$ gave $36(183 \mathrm{mg}, 0.90$ mmol, 65\%) as an orange oil: IR 3408, 2941, 1665, 1517, $1340 \mathrm{~cm}^{-1} ;{ }^{1} \mathrm{H}$ NMR $\delta 2.78(\mathrm{q}, J=5.1$ $\mathrm{Hz}, 2 \mathrm{H}), 3.14(\mathrm{t}, J=5.1 \mathrm{~Hz}, 2 \mathrm{H}), 6.81(\mathrm{t}, J=5.1 \mathrm{~Hz}, 1 \mathrm{H}), 7.19-7.70(\mathrm{~m}, 7 \mathrm{H}), 8.07(\mathrm{dd}, J=8.1$

and $2.9 \mathrm{~Hz}, 1 \mathrm{H}) ;{ }^{13} \mathrm{C}$ NMR $\delta 30.6(+), 33.7(+), 124.3(-), 127.0(-), 128.2(-), 128.6(-), 129.9(-)$, $132.1(-), 132.5(-), 133.4(-), 136.2(+), 139.1(+), 140.9(+), 141.5(+), 144.2(-), 148.1(+)$, $194.2(+)$; HRMS (DEI) calcd for $\mathrm{C}_{14} \mathrm{H}_{15} \mathrm{NO}_{4}\left(\mathrm{MH}^{+}\right)$280.0974, found 280.0964.

Impurity: 1-nitro-2-(2-nitrophenyl)benzene (43). Partial ${ }^{1} \mathrm{H}$ NMR $\delta 8.23(\mathrm{~d}, J=8.1$ Hz). Partial ${ }^{13} \mathrm{C}$ NMR $\delta 124.8,129.2,130.9,133.5$.

\section{2-(4-Methoxy-2-nitrophenyl)-2-cyclohexen-1-one (37).}

The same procedure as described for $\mathbf{3 2}$ was repeated except that a mixture of 2-(tri- $n$ butylstannyl)-2-cyclohexen-1-one (24) (183 mg, $0.48 \mathrm{mmol}$ ), 1-bromo-2-nitro-4methoxybenzene $(27)^{58}(103 \mathrm{mg}, 0.44 \mathrm{mmol}), \mathrm{PdCl}_{2}(\mathrm{PhCN})_{2}(8.2 \mathrm{mg}, 0.02 \mathrm{mmol}), \mathrm{dppf}(24.1$ mg, $0.04 \mathrm{mmol}), \mathrm{CuI}(8.9 \mathrm{mg}, 0.04 \mathrm{mmol})$, and NMP (1 mL) after 3 days gave 37 (73.4 mg, $0.30 \mathrm{mmol}, 67 \%$ ) as a yellow-orange solid: $\mathrm{mp} 63-65{ }^{\circ} \mathrm{C}$; IR $1682,1531,1357,1234 \mathrm{~cm}^{-1} ;{ }^{1} \mathrm{H}$ NMR $\delta 2.14$ (pentet, $J=5.9 \mathrm{~Hz}, 2 \mathrm{H}), 2.52-2.60(\mathrm{~m}, 4 \mathrm{H}), 3.85(\mathrm{~s}, 3 \mathrm{H}), 6.96(\mathrm{t}, J=4.1,1 \mathrm{H}), 7.13$ $7.16(\mathrm{~m}, 2 \mathrm{H}), 7.55(\mathrm{~d}, J=3.9 \mathrm{~Hz}, 1 \mathrm{H}) ;{ }^{13} \mathrm{CNMR} \delta 22.6(+), 26.2(+), 38.3(+), 55.8(-), 109.1(-$ ), $119.5(-), 124.1(+), 132.4(-), 139.0(+), 146.2(-), 149.0(+), 159.5(+), 196.8(+)$; HRMS (EI) calcd for $\mathrm{C}_{13} \mathrm{H}_{13} \mathrm{NO}_{3}\left(\mathrm{M}^{+}\right)$247.0845, found 247.0849. 


\section{2-(6-Methyl-2-nitrophenyl)-2-cyclohexen-1-one (38).}

The same procedure as described for $\mathbf{3 2}$ was repeated except that a mixture of 2-(tri- $n$ butylstannyl)-2-cyclohexen-1-one (24) (351 mg, $0.91 \mathrm{mmol}$ ), 2-bromo-3-nitrotoluene (28) (177 $\mathrm{mg}, 0.82 \mathrm{mmol}), \mathrm{PdCl}_{2}\left(\mathrm{PPh}_{3}\right)_{2}(27.7 \mathrm{mg}, 0.04 \mathrm{mmol})$, and $\mathrm{DMF}(5 \mathrm{~mL})$ heated at $110{ }^{\circ} \mathrm{C}$ for $26 \mathrm{~h}$ gave 38 (58.2 $\mathrm{mg}, 0.25 \mathrm{mmol}, 31 \%)$ as a pale yellow solid: $\mathrm{mp} 79-80{ }^{\circ} \mathrm{C}$; IR 1671, 1520, 1356 $\mathrm{cm}^{-1} ;{ }^{1} \mathrm{H}$ NMR $\delta .09-2.20(\mathrm{~m}, 2 \mathrm{H}), 2.22(\mathrm{~s}, 3 \mathrm{H}), 2.51(\mathrm{q}, J=5.7,2 \mathrm{H}), 2.57-2.74(\mathrm{~m}, 2 \mathrm{H}), 6.72$ (t, $J=4.2 \mathrm{~Hz}, 1 \mathrm{H}), 7.33(\mathrm{t}, J=7.8 \mathrm{~Hz}, 1 \mathrm{H}), 7.46(\mathrm{~d}, J=7.5 \mathrm{~Hz}, 1 \mathrm{H}), 7.78(\mathrm{~d}, J=8.1 \mathrm{~Hz}, 1 \mathrm{H})$; ${ }^{13}$ C NMR ọ 20.0 (-), $22.5(+), 26.0(+), 38.2(+), 121.6(-), 127.9(-), 131.4(+), 134.4(-), 137.2$ (+), $138.3(+), 146.8(-), 149.4(+), 196.8(+)$; HRMS (EI) calcd for $\mathrm{C}_{13} \mathrm{H}_{13} \mathrm{NO}_{3}\left(\mathrm{M}^{+}\right)$231.0895, found 231.0902 .

\section{2-(3-Methyl-2-nitrophenyl)-2-cyclohexen-1-one (39).}

The same procedure as described for 32 was repeated except that a mixture of 2-(tri- $n$ butylstannyl)-2-cyclohexen-1-one (24) (385 mg, 1.00 mmol), 3-iodo-2-nitrotoluene (29) (215 mg, $0.82 \mathrm{mmol}), \mathrm{PdCl}_{2}\left(\mathrm{PhCN}_{2}\right.$ (15.7 mg, $\left.0.04 \mathrm{mmol}\right), \mathrm{Ph}_{3} \mathrm{As}$ (25.3 mg, $\left.0.08 \mathrm{mmol}\right), \mathrm{CuI}(16.1$ $\mathrm{mg}, 0.08 \mathrm{mmol})$, and NMP (2.5 mL) after 2 days gave $39(117 \mathrm{mg}, 0.51 \mathrm{mmol}, 62 \%)$ as a pale yellow solid: mp 129-131 ${ }^{\circ} \mathrm{C}$; IR 1677, 1523, $1362 \mathrm{~cm}^{-1}$; ${ }^{1} \mathrm{H}$ NMR $\delta .2 .10$ (pentet, $J=6.2 \mathrm{~Hz}$, 2H), $2.39(\mathrm{~s}, 3 \mathrm{H}), 2.48-2.58(\mathrm{~m}, 4 \mathrm{H}), 6.99(\mathrm{t}, J=4.3 \mathrm{~Hz}, 1 \mathrm{H}), 7.07(\mathrm{~d}, J=7.6 \mathrm{~Hz}, 1 \mathrm{H}), 7.26(\mathrm{~d}, J$ $=7.8 \mathrm{~Hz}, 1 \mathrm{H}), 7.37(\mathrm{t}, J=7.5 \mathrm{~Hz}, 1 \mathrm{H}) ;{ }^{13} \mathrm{C}$ NMR $\delta 118.5(-), 22.5(+), 26.3(+), 38.3(+), 128.9$ (-), $130.4(-), 130.6(+), 130.7(+), 131.2(-), 137.8(+), 148.6(-), 150.3(+), 196.5(+) ;$ HRMS (EI) calcd for $\mathrm{C}_{13} \mathrm{H}_{13} \mathrm{NO}_{3}\left(\mathrm{M}^{+}\right)$231.0895, found 231.0898 . 


\section{2-(6-Carbomethoxy-2-nitrophenyl)-2-cyclohexen-1-one (40).}

The same procedure as described for $\mathbf{3 2}$ was repeated except that a mixture of 2-(tri- $n$ butylstannyl)-2-cyclohexen-1-one (24) (887 mg, $2.30 \mathrm{mmol}$ ), 1-carbomethoxy-2-bromo-3nitrobenzene $(\mathbf{3 0})^{10}(501 \mathrm{mg}, 1.92 \mathrm{mmol}), \mathrm{PdCl}_{2}(\mathrm{PhCN})_{2}(38.2 \mathrm{mg}, 0.10 \mathrm{mmol}), \mathrm{Ph}_{3} \mathrm{As}(59.8 \mathrm{mg}$, $0.20 \mathrm{mmol}), \mathrm{CuI}(39.7 \mathrm{mg}, 0.20 \mathrm{mmol})$, and NMP (4 mL) was degassed by four freeze-pumpthaw cycles $\left(-78{ }^{\circ} \mathrm{C}\right.$ to $\left.\mathrm{rt}\right)$ and was heated at $80{ }^{\circ} \mathrm{C}$ for $96 \mathrm{~h}$ to give 40 (233 $\left.\mathrm{mg}, 0.84 \mathrm{mmol}, 44 \%\right)$ as a yellow-orange solid: $\operatorname{mp} 86.5-88.5^{\circ} \mathrm{C}$; IR 1730, 1681, 1531, 1357, 1294, $1273 \mathrm{~cm}^{-1}$; ${ }^{1} \mathrm{H}$ NMR $\delta 2.15$ (pentet, $J=6.3 \mathrm{~Hz}, 2 \mathrm{H}), 2.47(\mathrm{q}, J=5.3 \mathrm{~Hz}, 2 \mathrm{H}), 2.63(\mathrm{t}, J=6.3 \mathrm{~Hz}, 2 \mathrm{H}), 6.66(\mathrm{t}, J$ $=4.1 \mathrm{~Hz}, 1 \mathrm{H}), 7.53(\mathrm{t}, J=7.9 \mathrm{~Hz}, 1 \mathrm{H}) 7.99(\mathrm{~d}, J=8.1,1 \mathrm{H}), 8.12(\mathrm{~d}, J=7.9 \mathrm{~Hz}, 1 \mathrm{H}) ;{ }^{13} \mathrm{C} \mathrm{NMR}$ $\delta 22.2(+), 26.0(+), 38.0(+), 52.3(-), 126.9(-), 128.5(-), 132.5(+), 132.7(+), 133.8(-), 136.9$ (+), $144.6(-), 150.3(+), 165.4(+), 196.3(+)$; HRMS (EI) calcd for $\mathrm{C}_{14} \mathrm{H}_{15} \mathrm{NO}_{4}\left(\mathrm{M}^{+}\right)$275.0794, found 275.0804 .

Impurity: Methyl 2-butyl-3-nitrobenzoate (44). ${ }^{1} \mathrm{H}$ NMR $\delta 0.91(\mathrm{t}, J=7.3 \mathrm{~Hz}, 3 \mathrm{H})$, 1.25-1.42 (m, 4H), 1.64 (pentet, $J=6.9,2 \mathrm{H}), 3.63(\mathrm{~s}, 3 \mathrm{H}), 7.68(\mathrm{t}, J=7.9 \mathrm{~Hz}, 1 \mathrm{H}), 8.28-8.33(\mathrm{~m}$,

2H). Partial ${ }^{13}$ C NMR $\delta 13.4(-), 17.4(+), 26.6(+), 27.6(+), 52.4(-), 127.7$ (-), $128.8(-), 134.7$ $(-)$.

\section{2-(5-Bromo-2-nitrophenyl)-2-cyclohexen-1-one (41).}

The same procedure as described for $\mathbf{3 2}$ was repeated except that a mixture of 2-(tri- $n$ butylstannyl)-2-cyclohexen-1-one (24) (459 mg, 1.19 mmol), 4-bromo-2-iodo-1-nitrobenzene (31) (318 mg, $0.97 \mathrm{mmol}), \mathrm{PdCl}_{2}(\mathrm{PhCN})_{2}(18.9 \mathrm{mg}, 0.05 \mathrm{mmol}), \mathrm{Ph}_{3} \mathrm{As}(30.5 \mathrm{mg}, 0.10 \mathrm{mmol})$, $\mathrm{CuI}$ (18.2 mg, $0.10 \mathrm{mmol})$, and NMP (3 mL) after 2 days gave 41 (160 mg, $0.54 \mathrm{mmol}, 56 \%)$ as a yellow-orange solid: $\mathrm{mp} 168-169{ }^{\circ} \mathrm{C}$; IR 2948, 1668, 1520, 1557, 1520, $1348 \mathrm{~cm}^{-1} ;{ }^{1} \mathrm{H}$ NMR $\delta$ 
$2.14(\mathrm{p}, J=5.8 \mathrm{~Hz}, 2 \mathrm{H}), 2.52-2.61(\mathrm{~m}, 4 \mathrm{H}), 7.02(\mathrm{t}, J=3.2 \mathrm{~Hz}, 1 \mathrm{H}), 7.41(\mathrm{~d}, J=3.5,1 \mathrm{H}), 7.59$

$(\mathrm{dd}, J=8.9$ and $3.4 \mathrm{~Hz}, 1 \mathrm{H}), 7.90(\mathrm{~d}, J=8.7 \mathrm{~Hz}, 1 \mathrm{H}) ;{ }^{13} \mathrm{C}$ NMR $\delta 22.4(+), 26.2(+), 38.1(+)$,

$125.7(-), 127.9(+), 131.7(-), 133.9(+), 134.4(-), 134.5(+), 138.4(+), 147.3(-), 196.1(+)$;

HRMS (DEI) calcd for $\mathrm{C}_{12} \mathrm{H}_{10} \mathrm{BrNO}_{3}\left(\mathrm{M}^{+}\right)$295.9923, found 295.9915 .

[(6,7-Dihydro-5H-benzocyclohepten-9-yl)oxy]trimethylsilane ${ }^{59}$ (49).

Butyllithium (10.7 $\mathrm{mL}$ of a 1.6 M solution in hexanes, $17.1 \mathrm{mmol})$ was added dropwise to a solution of diisopropylamine $(2.85 \mathrm{~mL}, 20.3 \mathrm{mmol})$ in THF $(42 \mathrm{~mL})$ cooled to $-78{ }^{\circ} \mathrm{C}$. The reaction mixture was stirred $5 \mathrm{~min}$, and a solution of 1-benzosuberone $(2.49 \mathrm{~g}, 15.6 \mathrm{mmol})$ in THF $(13 \mathrm{~mL})$ was added slowly to the reaction mixture. The reaction mixture was stirred for 45 min, and then $\mathrm{TMSCl}(2.4 \mathrm{~mL}, 18.9 \mathrm{mmol})$ and $\mathrm{Et}_{3} \mathrm{~N}(4.35 \mathrm{~mL}, 31.2 \mathrm{mmol})$ were added slowly. The reaction mixture was allowed to warm to ambient temperature over $1 \mathrm{~h}$. The reaction mixture was diluted with diethyl ether $(200 \mathrm{~mL})$, washed with water $(3 \times 50 \mathrm{~mL})$, dried $\left(\mathrm{MgSO}_{4}\right)$, and concentrated. The crude product was purified by flash chromatography (hexanes/Et $2 \mathrm{O}, 9: 1)$ to give 49 (3.43 g, $14.8 \mathrm{mmol}, 95 \%)$ as a clear, colorless oil.

\section{8,9-Dihydro-5H-benzocyclohepten-5-one ${ }^{60}(50)$.}

To a solution of 49 (3.04 g, $13.1 \mathrm{mmol})$ in DMSO $(100 \mathrm{~mL})$ was added $\mathrm{Pd}(\mathrm{OAc})_{2}(293$ $\mathrm{mg}, 1.30 \mathrm{mmol})$. The reaction flask was flushed with $\mathrm{O}_{2}$ for $5 \mathrm{~min}$. The reaction mixture was stirred at $40{ }^{\circ} \mathrm{C}$ under $\mathrm{O}_{2}(1 \mathrm{~atm}$, balloon) for $27 \mathrm{~h}$. The reaction mixture was allowed to cool, and then was diluted with $400 \mathrm{~mL}$ of EtOAc and washed with water $(3 \times 100 \mathrm{~mL})$. The organic phase was dried $\left(\mathrm{MgSO}_{4}\right)$ and concentrated. The crude product was purified by flash 
chromatography (hexanes:EtOAc, 9:1) to give $\mathbf{5 0}(1.92 \mathrm{~g}, 12.2 \mathrm{mmol}, 93 \%)$ as a clear, colorless oil.

\section{1,2-Dihydrocarbazol-4(3H)-one ${ }^{4}(5)$.}

2-(2-Nitrophenyl)-2-cyclohexen-1-one (32) (285 mg, $1.31 \mathrm{mmol}), \mathrm{Pd}(\mathrm{dba})_{2}$ (45.3 mg, $0.08 \mathrm{mmol}$ ), dppp (32.5 mg, $0.08 \mathrm{mmol}), 1,10$-phenanthroline monohydrate $(31.2 \mathrm{mg}, 0.16$ $\mathrm{mmol})$, and DMF ( $5 \mathrm{~mL}$ ) were placed into a pressure tube fitted with a pressure head. The tube was flushed 3 times with $\mathrm{CO}$, and the reaction was heated and stirred at $80{ }^{\circ} \mathrm{C}$ under $\mathrm{CO}(90 \mathrm{psi})$ for $24 \mathrm{~h}$. The reaction mixture was filtered through Celite and was concentrated under high vacuum. The product was purified via flash chromatography (hexanes/EtOAc, 7:3) to give 5 (180 $\mathrm{mg}, 0.97 \mathrm{mmol}, 74 \%)$ as a white powder.

Alternate procedure A for compound 5. Compound $\mathbf{5}$ was also prepared using the above procedure except that a mixture of 2-(2-nitrophenyl)-1,3-cyclohexanedione ${ }^{23}$ (70) (202 $\mathrm{mg}, 0.87 \mathrm{mmol}), \mathrm{Pd}(\mathrm{dba})_{2}(29.7 \mathrm{mg}, 0.05 \mathrm{mmol})$, dppp (22.5 mg, $\left.0.05 \mathrm{mmol}\right), 1,10-$ phenanthroline monohydrate $(23.5 \mathrm{mg}, 0.12 \mathrm{mmol})$, and DMF $(5 \mathrm{~mL})$ heated at $100{ }^{\circ} \mathrm{C}$ for $90 \mathrm{~h}$ gave 5 (133 mg, $0.72 \mathrm{mmol}, 83 \%)$.

Alternate procedure $\mathbf{B}$ for compound 5. Compound $\mathbf{5}$ was also prepared using the above procedure except that a mixture of 3-methoxy-2-(2-nitrophenyl)-2-cyclohexen-1-one ${ }^{23}$ (71) (141 mg, $0.57 \mathrm{mmol}), \operatorname{Pd}(\mathrm{dba})_{2}(20.6 \mathrm{mg}, 0.04 \mathrm{mmol})$, dppp (16.3 mg, $\left.0.04 \mathrm{mmol}\right), 1,10-$ phenanthroline monohydrate $(15.4 \mathrm{mg}, 0.08 \mathrm{mmol})$, and DMF $(5 \mathrm{~mL})$ heated at $120{ }^{\circ} \mathrm{C}$ for $96 \mathrm{~h}$ gave 5 (64.5 mg, $0.35 \mathrm{mmol}, 61 \%)$. 


\section{2-Methyl-1,2-dihydrocarbazol-4(3H)-one (55).}

The same procedure as described for 5 was repeated except that a mixture of 5-methyl-2(2-nitrophenyl)-2-cyclohexenone (33) $(98.3 \mathrm{mg}, 0.42 \mathrm{mmol}), \mathrm{Pd}(\mathrm{dba})_{2}(14.7 \mathrm{mg}, 0.03 \mathrm{mmol})$, dppp (10.5 mg, $0.03 \mathrm{mmol}), 1,10$-phenanthroline monohydrate (10.2 mg, $0.05 \mathrm{mmol})$, and DMF (5 mL) after $36 \mathrm{~h}$ gave 55 (75.1 mg, $0.38 \mathrm{mmol}, 89 \%)$ as a white powder: $\mathrm{mp} \mathrm{260-261}{ }^{\circ} \mathrm{C}$; IR (Nujol) 2925, 1630, 1583, 1458, $1376 \mathrm{~cm}^{-1} ;{ }^{1} \mathrm{H}$ NMR $\left(\mathrm{CDCl}_{3}+\mathrm{DMSO}_{-} \mathrm{d}_{6}\right) \delta 1.19(\mathrm{~d}, J=6.2 \mathrm{~Hz}$, 3H), 2.22-2.71 (m, 4H), 2.98-3.11 (m, 1H), 7.11-7.21 (m, 2H), 7.32-7.40 (m, 1H), 8.04-8.12 (m, 1H), $11.25(\mathrm{~s}, 1 \mathrm{H}) ;{ }^{13} \mathrm{C} \mathrm{NMR}\left(\mathrm{CDCl}_{3}+\mathrm{DMSO}_{-\mathrm{d}}\right) \delta 20.3(-), 30.4(+), 30.7(-), 45.6(+), 110.5$ (-), $111.1(+), 119.7(-), 120.7(-), 121.6(-), 123.7(+), 135.4(+), 150.8(+), 192.4(-)$.

\section{3,4-Dihydrocyclopent $[b]$ indol-1(2H)-one ${ }^{61}(56)$.}

The same procedure as described for 5 was repeated except that a mixture of 2-(2nitrophenyl)-2-cyclopenten-1-one (34) (125 mg, $0.61 \mathrm{mmol}), \mathrm{Pd}(\mathrm{dba})_{2}(21.2 \mathrm{mg}, 0.04 \mathrm{mmol})$, dppp (15.7 mg, $0.04 \mathrm{mmol}), 1,10$-phenanthroline monohydrate (14.8 mg, $0.07 \mathrm{mmol}$ ), and DMF (5 mL) after 3 days gave $56(90.4 \mathrm{mg}, 0.53 \mathrm{mmol}, 86 \%)$ as a white powder.

\section{6,7,8,9-Tetrahydrocyclohept $[b]$ indol-10 $(5 H)-$ one $^{5}(57)$.}

The same procedure as described for 5 was repeated except that a mixture of 2-(2nitrophenyl)-2-cycloheptenone (35) (136 mg, $0.59 \mathrm{mmol}), \mathrm{Pd}(\mathrm{dba})_{2}(20.4 \mathrm{mg}, 0.04 \mathrm{mmol})$, dppp (14.5 mg, $0.04 \mathrm{mmol}), 1,10$-phenanthroline monohydrate (14.7 mg, $0.07 \mathrm{mmol})$, and DMF (5 $\mathrm{mL})$ after $48 \mathrm{~h}$ gave $57(77.9 \mathrm{mg}, 0.39 \mathrm{mmol}, 66 \%)$ as a white powder. 
6,7-Dihydrobenzo[4,5]cyclohept-[1,2-b]indol-12(5H)-one ${ }^{8}(58)$.

The same procedure as described for 5 was repeated except that a mixture of $\mathbf{3 6}(31.5 \mathrm{mg}$, $0.11 \mathrm{mmol}), \mathrm{Pd}(\mathrm{dba})_{2}(5.1 \mathrm{mg}, 0.009 \mathrm{mmol})$, dppp (3.5 mg, $\left.0.009 \mathrm{mmol}\right), 1,10$-phenanthroline monohydrate (3.4 mg, $0.017 \mathrm{mmol})$, and DMF (3 mL) after $30 \mathrm{~h}$ gave 58 (24.1 mg, $0.098 \mathrm{mmol}$, $86 \%$ ) as a white powder.

\section{7-Methoxy-1,2-dihydrocarbazol-4(3H)-one $\mathrm{e}^{5}(59)$.}

The same procedure as described for 5 was repeated except that a mixture of 2-(4methoxy-2-nitrophenyl)-2-cyclohexen-1-one (37) (43.5 mg, $0.18 \mathrm{mmol}), \mathrm{Pd}(\mathrm{dba})_{2}(6.3 \mathrm{mg}, 0.01$ mmol), dppp (4.6 mg, $0.01 \mathrm{mmol}), 1,10$-phenanthroline monohydrate (4.5 mg, $0.02 \mathrm{mmol})$, and DMF (5 mL) after $22 \mathrm{~h}$ gave $\mathbf{5 9}(33.8 \mathrm{mg}, 0.16 \mathrm{mmol}, 89 \%)$ as a white powder.

\section{5-Methyl-1,2-dihydrocarbazol-4(3H)-one (60).}

The same procedure as described for 5 was repeated except that a mixture of 2-(6-methyl2-nitrophenyl)-2-cyclohexen-1-one (38) (117 mg, $0.51 \mathrm{mmol}), \mathrm{Pd}(\mathrm{dba})_{2}(17.5 \mathrm{mg}, 0.03 \mathrm{mmol})$, dppp (12.7 mg, $0.03 \mathrm{mmol}), 1,10$-phenanthroline monohydrate (12.4 mg, $0.06 \mathrm{mmol}$ ), and DMF (5 mL) after $36 \mathrm{~h}$ gave $\mathbf{6 0}(79.5 \mathrm{mg}, 0.40 \mathrm{mmol}, 79 \%)$ as a white powder: $\mathrm{mp} 234-235^{\circ} \mathrm{C}$; IR (Nujol) 1711, 1620, $1575 \mathrm{~cm}^{-1} ;{ }^{1} \mathrm{H} \mathrm{NMR}\left(\mathrm{CDCl}_{3}+\mathrm{DMSO}_{6}\right) \delta 2.16$ (pentet, $\left.J=5.9 \mathrm{~Hz}, 2 \mathrm{H}\right)$, $2.50(\mathrm{t}, J=5.9 \mathrm{~Hz}, 2 \mathrm{H}), 2.86(\mathrm{~s}, 3 \mathrm{H}), 2.97(\mathrm{t}, J=5.9 \mathrm{~Hz}, 2 \mathrm{H}), 6.88(\mathrm{~d}, J=7.2,1 \mathrm{H}), 7.03(\mathrm{t}, J=$

$7.4 \mathrm{~Hz}, 1 \mathrm{H}), 7.15(\mathrm{~d}, J=8.2 \mathrm{~Hz}, 1 \mathrm{H}), 11.47(\mathrm{~s}, 1 \mathrm{H}) ;{ }^{13} \mathrm{C} \mathrm{NMR}_{\left(\mathrm{CDCl}_{3}+\mathrm{DMSO}_{\mathrm{d}}\right) \delta} 23.3(-)$, $23.6(+), 23.9(+), 38.9(+), 109.4(-), 113.5(+), 123.2(-), 123.7(-), 124.6(+), 131.7(+), 137.0$ (+), $153.0(+), 192.1(+)$; HRMS (EI) calcd for $\mathrm{C}_{13} \mathrm{H}_{13} \mathrm{NO}\left(\mathrm{M}^{+}\right)$199.0997, found 199.0997. 
8-Methyl-1,2-dihydrocarbazol-4(3H)-one ${ }^{6}(61)$.

The same procedure as described for 5 was repeated except that a mixture of 2-(3-methyl2-nitrophenyl)-2-cyclohexen-1-one (39) (108 mg, $0.47 \mathrm{mmol}), \mathrm{Pd}(\mathrm{dba})_{2}(16.5 \mathrm{mg}, 0.03 \mathrm{mmol})$, dppp (11.9 mg, $0.03 \mathrm{mmol}), 1,10$-phenanthroline monohydrate (11.4 mg, $0.06 \mathrm{mmol}$ ), and DMF (5 mL) after $144 \mathrm{~h}$ gave $61(69.8 \mathrm{mg}, 0.35 \mathrm{mmol}, 75 \%)$ as a white powder.

\section{Methyl 1,2-dihydrocarbazol-4(3H)-one-5-carboxylate ${ }^{62}(62)$.}

The same procedure as described for 5 was repeated except that a mixture of 2-(6carbomethoxy-2-nitrophenyl)-2-cyclohexen-1-one (40) (158 mg, $0.57 \mathrm{mmol}), \mathrm{Pd}(\mathrm{dba})_{2}(19.7 \mathrm{mg}$, $0.03 \mathrm{mmol})$, dppp (14.2 mg, $0.03 \mathrm{mmol}), 1,10$-phenanthroline monohydrate (13.6 mg, 0.07 $\mathrm{mmol}$ ), and DMF (5 mL) after $96 \mathrm{~h}$ gave $62(105 \mathrm{mg}, 0.43 \mathrm{mmol}, 75 \%)$ as a white powder.

\section{6-Bromo-1,2,3,9-tetrahydro-4H-carbazol-4-one ${ }^{63}(63)$.}

The same procedure as described for 5 was repeated except that a mixture of 2-(5-bromo2-nitrophenyl)-2-cyclohexen-1-one (41) (123 mg, $0.42 \mathrm{mmol}), \operatorname{Pd}(\mathrm{dba})_{2}(14.3 \mathrm{mg}, 0.025 \mathrm{mmol})$, dppp (10.4 mg, $0.025 \mathrm{mmol}), 1,10$-phenanthroline monohydrate $(9.9 \mathrm{mg}, 0.050 \mathrm{mmol})$, and DMF (5 mL) after 8 days gave $\mathbf{6 3}(56.9 \mathrm{mg}, 0.22 \mathrm{mmol}, 79 \%)$ as a white powder.

\section{6,7,8,9-Tetrahydro-5H-pyrido[3,2-b]indol-9-one ${ }^{7}(68)$.}

A mixture of 2-(tri-n-butylstannyl)-2-cyclohexen-1-one (24) (621 mg, $1.61 \mathrm{mmol}), 2$ chloro-3-nitropyridine (66) (201 mg, $1.26 \mathrm{mmol}), \mathrm{Pd}(\mathrm{dba})_{2}(22.1 \mathrm{mg}, 0.038 \mathrm{mmol}), \mathrm{Ph}_{3} \mathrm{As}(47.1$ $\mathrm{mg}, 0.15 \mathrm{mmol})$, and toluene $(5 \mathrm{~mL})$ were heated at reflux for $20 \mathrm{~h}$. The reaction was diluted with benzene $(100 \mathrm{~mL})$ and washed with $\mathrm{NH}_{4} \mathrm{OH}(10 \%$, aq, 3 X $50 \mathrm{~mL})$ and $\mathrm{H}_{2} \mathrm{O}(2 \mathrm{X} 50 \mathrm{~mL})$. 
The organic phase was dried $\left(\mathrm{MgSO}_{4}\right)$ and concentrated. The crude product $(\mathbf{6 7})$ was used in the next procedure without purification. The same procedure as described for $\mathbf{5}$ was repeated except that the mixture of crude $67, \operatorname{Pd}(\mathrm{dba})_{2}(43.6 \mathrm{mg}, 0.075 \mathrm{mmol})$, dppp (31.2 $\left.\mathrm{mg}, 0.076 \mathrm{mmol}\right)$, 1,10-phenanthroline monohydrate $(30.1 \mathrm{mg}, 0.152 \mathrm{mmol})$, and DMF ( $5 \mathrm{~mL})$ after purification by flash chromatography $\left(\mathrm{CHCl}_{3}\right.$ to $\left.\mathrm{CHCl}_{3} / \mathrm{MeOH}, 9: 1\right)$ gave $\mathbf{6 8}(128 \mathrm{mg}, 0.685 \mathrm{mmol}, 54 \%)$ as a tan solid.

\section{2-Iodo-6-methyl-2-cyclohexen-1-one (114).}

To a solution of 6-methyl-2-cyclohexen-1-one ${ }^{19}(\mathbf{1 1 3})(441 \mathrm{mg}, 4.00 \mathrm{mmol})$ in $20 \mathrm{~mL}$ of 1:1 $\mathrm{CCl}_{4} /$ pyridine cooled to $0{ }^{\circ} \mathrm{C}$ was added dropwise a solution of iodine $(2.09 \mathrm{~g}, 8.23 \mathrm{mmol})$ dissolved in $20 \mathrm{~mL}$ of $1: 1 \mathrm{CCl}_{4} /$ pyridine with stirring. The reaction was allowed to warm to ambient temperature overnight. The reaction mixture was diluted with ether $(100 \mathrm{~mL})$ and washed successively with water $(40 \mathrm{~mL}), \mathrm{HCl}(5 \%$, aq, 2 x $40 \mathrm{~mL})$, water $(40 \mathrm{~mL})$, and $\mathrm{Na}_{2} \mathrm{~S}_{2} \mathrm{O}_{3}$ (20\%, aq, $40 \mathrm{~mL})$. The organic phase was dried $\left(\mathrm{MgSO}_{4}\right)$ and concentrated under vacuum. The crude product was purified by flash chromatography (hexanes/EtOAc, 9:1) to give 114 (675 mg, $2.86 \mathrm{mmol}, 71 \%)$ as a light yellow oil: IR 2929, 1682, 1594, $1454 \mathrm{~cm}^{-1} ;{ }^{1} \mathrm{H}$ NMR $\delta 1.21(\mathrm{~d}, J=$

$6.7 \mathrm{~Hz}, 3 \mathrm{H}), 1.75-1.91(\mathrm{~m}, 1 \mathrm{H}), 2.06-2.18(\mathrm{~m}, 1 \mathrm{H}), 2.35-2.68(\mathrm{~m}, 3 \mathrm{H}), 7.68-7.73(\mathrm{~m}, 1 \mathrm{H}) ;{ }^{13} \mathrm{C}$ NMR $\delta 15.2(-), 29.0(+), 29.9(+), 40.7(-), 102.8(+), 158.3(-), 193.9(+)$; HRMS (EI) calcd for $\mathrm{C}_{7} \mathrm{H}_{9} \mathrm{IO}\left(\mathrm{M}^{+}\right)$235.9698, found 235.9688.

\section{2-(2-Nitrophenyl)-6-methyl-2-cyclohexen-1-one (115).}

The same procedure as described for 32 was repeated except that a mixture of 2-iodo-6methyl-2-cyclohexen-1-one (114) (606 mg, 2.57 mmol), 1-(tri- $n$-butylstannyl)-2-nitrobenzene 
(25) (1.26 g, $3.07 \mathrm{mmol}), \mathrm{PdCl}_{2}(\mathrm{PhCN})_{2}(48.9 \mathrm{mg}, 0.13 \mathrm{mmol}), \mathrm{Ph}_{3} \mathrm{As}$ (78.5 mg, $\left.0.26 \mathrm{mmol}\right)$,

CuI (48.7 mg, $0.26 \mathrm{mmol})$, and NMP (5 mL) after 1.5 days gave 115 (491 mg, $2.12 \mathrm{mmol}, 83 \%)$ as a pale yellow oil: IR 2931, 1679, 1524, $1349 \mathrm{~cm}^{-1} ;{ }^{1} \mathrm{H}$ NMR $\delta 1.19(\mathrm{~d}, J=6.7 \mathrm{~Hz}, 3 \mathrm{H}), 1.82-$ $1.98(\mathrm{~m}, 1 \mathrm{H}), 2.12-2.23(\mathrm{~m}, 1 \mathrm{H}), 2.50-2.67(\mathrm{~m}, 3 \mathrm{H}), 6.96(\mathrm{td}, J=3.6$ and $2.0 \mathrm{~Hz}, 1 \mathrm{H}), 7.26(\mathrm{dd}$, $J=8.3$ and $1.6 \mathrm{~Hz}, 1 \mathrm{H}), 7.47(\mathrm{td}, J=7.5$ and $1.6 \mathrm{~Hz}, 1 \mathrm{H}), 7.59(\mathrm{td}, J=7.7$ and $1.6 \mathrm{~Hz}, 1 \mathrm{H}), 8.02$

$(\mathrm{dd}, J=8.1$ and $1.4 \mathrm{~Hz}, 1 \mathrm{H}) ;{ }^{13} \mathrm{C}$ NMR $\delta 14.7(-), 25.5(+), 30.3(+), 41.5(-), 123.9(-), 128.5(-)$, $131.6(-), 132.1(+), 133.2(-), 138.6(+), 146.0(-), 148.3(+), 198.9(+)$; HRMS (DEI) calcd for $\mathrm{C}_{13} \mathrm{H}_{13} \mathrm{NO}_{3}\left(\mathrm{MH}^{+}\right)$232.0974, found 232.0968.

Impurity: 1-nitro-2-(2-nitrophenyl)benzene (43). ${ }^{1} \mathrm{H}$ NMR $\delta 7.30$ (dd, $J=8.1$ and 1.6 $\mathrm{Hz}), 7.70(\mathrm{td}, J=7.5$ and $1.6 \mathrm{~Hz}), 8.23(\mathrm{dd}, J=8.1$ and $1.6 \mathrm{~Hz})$. Partial ${ }^{13} \mathrm{C} \mathrm{NMR} \delta 124.4$, $128.9,130.8,134.0$.

\section{1,2,3,9-Tetrahydro-3-methyl-4H-carbazol-4-one $\mathrm{e}^{35}$ (116).}

The same procedure as described for 5 was repeated except that a mixture of 6-methyl-2(2-nitrophenyl)-2-cyclohexenone (115) (187 mg, $0.80 \mathrm{mmol}), \mathrm{Pd}(\mathrm{dba}) 2$ (31.0 mg, $0.05 \mathrm{mmol})$, dppp (22.2 mg, $0.05 \mathrm{mmol}), 1,10$-phenanthroline monohydrate (21.4 mg, $0.10 \mathrm{mmol})$, and DMF (5 mL) after $48 \mathrm{~h}$ gave 116 (156 $\mathrm{mg}, 0.78 \mathrm{mmol}, 97 \%)$ as a white powder.

\section{3-Methyl-9H-carbazol-4-ol ${ }^{64}$ (117).}

A mixture of 3-methyl-1,2-dihydrocarbazol-4(3H)-one (116) (159 mg, $0.80 \mathrm{mmol}), 10 \%$ $\mathrm{Pd} / \mathrm{C}$ (108 mg), diphenyl ether (6 mL), and 1,2,4-trimethylbenzene $(0.75 \mathrm{~mL})$ was degassed by bubbling argon through the mixture for $10 \mathrm{~min}$. The reaction mixture was heated at $230{ }^{\circ} \mathrm{C}$ for $20 \mathrm{~h}$. The reaction was filtered through a short column of silica gel using petroleum ether 
followed by $\mathrm{CH}_{2} \mathrm{Cl}_{2}$ /formic acid (99.9:0.1) to give 117 (98.9 $\mathrm{mg}, 0.50 \mathrm{mmol}, 63 \%$ ) as a white solid.

\section{3-Iodo-5-methyl-2-cyclohexen-1-one (119).}

To a solution of triphenylphosphine $(4.75 \mathrm{~g}, 18.1 \mathrm{mmol})$ in acetonitrile $(80 \mathrm{~mL})$ was added iodine $(4.53 \mathrm{~g}, 17.8 \mathrm{mmol})$. The reaction mixture was stirred for $2 \mathrm{~h}$. Triethylamine (2.6 $\mathrm{mL}, 18.7 \mathrm{mmol}$ ) was added slowly, followed by 5-methyl-1,3-cyclohexanedione (2.04 g, 16.2 mmol). The reaction mixture was stirred for 14 days at ambient temperature. The solvent was evaporated, and the crude product was purified by flash chromatography (hexanes/EtOAc, 95:5) to give 119 (3.44 g, $14.6 \mathrm{mmol}, 90 \%)$ as a light yellow oil: IR 2956, 1676, $1592 \mathrm{~cm}^{-1} ;{ }^{1} \mathrm{H}$ NMR $\delta 1.07(\mathrm{dd}, J=6.5$ and $1.8 \mathrm{~Hz}, 3 \mathrm{H}), 2.10(\mathrm{ddd}, J=12.1,11.7$, and $3.6 \mathrm{~Hz}, 1 \mathrm{H}), 2.24-2.40(\mathrm{~m}$, 1H), 2.46-2.65 (m, 2H), 2.95-3.06 (m, 1H), 6.77-6.82 (m, 1H); ${ }^{13} \mathrm{C}$ NMR $\delta 19.9(-), 30.9(+)$, 44.0 (-), $47.6(-), 125.7$ (+), $139.4(-), 194.3$ (+); HRMS (EI) calcd for $\mathrm{C}_{7} \mathrm{H}_{9} \mathrm{IO}\left(\mathrm{M}^{+}\right)$235.9698, found 235.9696 .

\section{3-(2-Nitrophenyl)-5-methyl-2-cyclohexen-1-one (120).}

The same procedure as described for $\mathbf{3 2}$ was repeated except that a mixture of 3-iodo-5methyl-2-cyclohexen-1-one (119) (1.00 g, 4.24 mmol), 1-(tri- $n$-butylstannyl)-2-nitrobenzene (25) $(2.10 \mathrm{~g}, 5.08 \mathrm{mmol}), \mathrm{PdCl}_{2}(\mathrm{PhCN})_{2}(81.3 \mathrm{mg}, 0.21 \mathrm{mmol}), \mathrm{Ph}_{3} \mathrm{As}$ (130 mg, $\left.0.42 \mathrm{mmol}\right), \mathrm{CuI}$ (80.8 mg, $0.42 \mathrm{mmol})$, and NMP ( $8.4 \mathrm{~mL})$ gave after $48 \mathrm{~h} \mathbf{1 2 0}(873 \mathrm{mg}, 3.78 \mathrm{mmol}, 89 \%)$ as a pale yellow solid: $\mathrm{mp} 62-64.5^{\circ} \mathrm{C}$; IR 2956, $1669,1525,1346 \mathrm{~cm}^{-1} ;{ }^{1} \mathrm{H}$ NMR $\delta 1.14$ (d, $J=5.5$ $\mathrm{Hz}, 3 \mathrm{H}), 2.13-2.63(\mathrm{~m}, 5 \mathrm{H}), 5.99(\mathrm{~s}, 1 \mathrm{H}), 7.32(\mathrm{~d}, J=7.5 \mathrm{~Hz}, 1 \mathrm{H}), 7.56(\mathrm{td}, J=7.5$ and $2.4 \mathrm{~Hz}$, $1 \mathrm{H}), 7.69(\mathrm{td}, J=7.7$ and $2.4 \mathrm{~Hz}, 1 \mathrm{H}), 8.11(\mathrm{~d}, J=8.1 \mathrm{~Hz}, 1 \mathrm{H}) ;{ }^{13} \mathrm{C} \mathrm{NMR} \delta 20.9(-), 30.7(-), 38.8$ 
(+), $45.4(+), 124.8(-), 127.1(-), 129.4(-), 129.6(-), 133.8(-), 136.4(+), 146.5(+), 159.8(+)$,

199.0 (+); HRMS (DEI) calcd for $\mathrm{C}_{13} \mathrm{H}_{13} \mathrm{NO}_{3}\left(\mathrm{MH}^{+}\right)$232.0974, found 232.0974 .

\section{2,3,4,9-Tetrahydro-3-methyl-1H-carbazol-1-one ${ }^{31}(1)$.}

The same procedure as described for $\mathbf{5}$ was repeated except that a mixture of 5-methyl-3(2-nitrophenyl)-2-cyclohexenone (120) (133 mg, $0.58 \mathrm{mmol}), \mathrm{Pd}(\mathrm{dba})_{2}(19.9 \mathrm{mg}, 0.03 \mathrm{mmol})$, dppp (14.3 mg, $0.03 \mathrm{mmol}), 1,10$-phenanthroline monohydrate (13.7 mg, $0.07 \mathrm{mmol})$, and DMF (6 $\mathrm{mL})$ after $72 \mathrm{~h}$ gave $\mathbf{1}(88.5 \mathrm{mg}, 0.44 \mathrm{mmol}, 77 \%)$ as a white powder.

\section{4-Iodo-3-nitrophenol ${ }^{65}$ (122).}

The same procedure as described for $\mathbf{2 9}$ was repeated except that 4-amino-3-nitrophenol (1.01 g, $6.55 \mathrm{mmol}$ ), water (8mL), concentrated $\mathrm{H}_{2} \mathrm{SO}_{4}(1 \mathrm{~mL}), \mathrm{NaNO}_{2}$ (506 mg, $\left.7.33 \mathrm{mmol}\right), \mathrm{KI}$ (1.30 g, $7.8 \mathrm{mmol})$, and Cu powder (8.00 mg, $0.13 \mathrm{mmol})$ gave $122(1.06 \mathrm{~g}, 4.00 \mathrm{mmol}, 61 \%)$ as a yellow solid.

\section{1-Iodo-2-nitro-4-methoxybenzene ${ }^{66}(123)$.}

4-iodo-3-nitrophenol (122) (1.00 g, $3.78 \mathrm{mmol})$, $\mathrm{MeI}$ (2.35 mL, $37.7 \mathrm{mmol}), \mathrm{K}_{2} \mathrm{CO}_{3}(2.63$ $\mathrm{g}, 19.0 \mathrm{mmol})$, and acetone $(16 \mathrm{~mL})$ were combined and heated at reflux for $20 \mathrm{~h}$. The reaction mixture was allowed to cool and was filtered. The filtrate was concentrated to yield $\mathbf{1 2 2}(1.05 \mathrm{~g}$, $3.78 \mathrm{mmol}, 100 \%$ ) as a yellow solid. 


\section{1-(tri- $n$-Butylstannyl)-2-nitro-4-methoxybenzene (124).}

To a solution of $\mathbf{1 2 3}(923 \mathrm{mg}, 3.32 \mathrm{mmol})$ in toluene $(6 \mathrm{~mL})$ was added hexabutylditin (2.50 mL, $4.95 \mathrm{mmol}), \mathrm{PdCl}_{2}\left(\mathrm{PPh}_{3}\right)_{2}(23.6 \mathrm{mg}, 0.03 \mathrm{mmol})$, and $\mathrm{PPh}_{3}(17.6 \mathrm{mg}, 0.06 \mathrm{mmol})$. The reaction was heated at $80{ }^{\circ} \mathrm{C}$ for 4 days. The reaction was diluted with benzene $(100 \mathrm{~mL})$ and washed with $\mathrm{NH}_{4} \mathrm{OH}(10 \%$, aq, 3 X $30 \mathrm{~mL})$ and $\mathrm{H}_{2} \mathrm{O}(2$ X $30 \mathrm{~mL})$. The organic phase was dried $\left(\mathrm{MgSO}_{4}\right)$ and concentrated. The product was purified by flash chromatography (hexanes) to give 124 (1.13 g, $2.55 \mathrm{mmol}, 77 \%$ ) as a yellow oil: IR 2956, 1528, $1344 \mathrm{~cm}^{-1} ;{ }^{1} \mathrm{H}$ NMR $\delta$ $0.87(\mathrm{t}, J=7.3 \mathrm{~Hz}, 3 \mathrm{H}), 1.10(\mathrm{t}, J=7.7 \mathrm{~Hz}, 2 \mathrm{H}), 1.30$ (sextet, $J=4.0 \mathrm{~Hz}, 2 \mathrm{H}), 1.42-1.54(\mathrm{~m}, 2 \mathrm{H})$, $3.89(\mathrm{~s}, 3 \mathrm{H}), 7.19(\mathrm{dd}, J=8.1$ and $2.6 \mathrm{~Hz}, 1 \mathrm{H}), 7.54(\mathrm{~d}, J=8.1 \mathrm{~Hz}, 1 \mathrm{H}), 7.85(\mathrm{~d}, J=4.3 \mathrm{~Hz}, 1 \mathrm{H})$; ${ }^{13} \mathrm{C}$ NMR $\delta 10.8(+), 13.6(-), 27.3(+), 29.0(+), 55.5(-), 108.8(-), 120.6(-), 130.0(+), 138.0(-)$, $154.5(+), 160.5(+)$ : HRMS (FAB) calcd for $\mathrm{C}_{19} \mathrm{H}_{33} \mathrm{NO}_{3} \mathrm{Sn}\left(\mathrm{M}^{-}\right)$443.1482, found 443.1491.

\section{3-(4-Methoxy-2-nitrophenyl)-5-methyl-2-cyclohexen-1-one (125).}

The same procedure as described for 32 was repeated except that a mixture of 3-iodo-5methyl-2-cyclohexen-1-one (119) (208 mg, 0.88 mmol), 1-(tri- $n$-butylstannyl)-4-methoxy-2nitrobenzene (124) (445 mg, $1.00 \mathrm{mmol}), \mathrm{PdCl}_{2}(\mathrm{PhCN})_{2}(17.2 \mathrm{mg}, 0.04 \mathrm{mmol}), \mathrm{Ph}_{3} \mathrm{As}(27.1 \mathrm{mg}$, $0.08 \mathrm{mmol}), \mathrm{CuI}(17.8 \mathrm{mg}, 0.09 \mathrm{mmol})$, and NMP (2 mL) after 2 days gave 125 (222 $\mathrm{mg}, 0.84$ mmol, $96 \%$ ) as a yellow solid: $\operatorname{mp} 45-47^{\circ} \mathrm{C}$; IR 2953, 1666, 1531, $1350 \mathrm{~cm}^{-1} ;{ }^{1} \mathrm{H}$ NMR $\delta 1.11$ $(\mathrm{d}, J=6.1,3 \mathrm{H}), 2.11-2.61(\mathrm{~m}, 5 \mathrm{H}), 3.9(\mathrm{~s}, 3 \mathrm{H}), 5.96(\mathrm{~s}, 1 \mathrm{H}), 7.18-7.21(\mathrm{~m}, 2 \mathrm{H}), 7.58(\mathrm{~d}, J=5.5$ $\mathrm{Hz}, 1 \mathrm{H}) ;{ }^{13} \mathrm{C}$ NMR $\delta 21.0(-), 30.7(-), 38.9(+), 45.4(+), 56.0(-), 109.81(-), 119.9(-), 127.3(-)$, $128.7(+), 130.7(-), 147.5(+), 159.9(+), 160.03(+), 199.34(-)$; HRMS (DEI) calcd for $\mathrm{C}_{14} \mathrm{H}_{15} \mathrm{NO}_{4}\left(\mathrm{MH}^{+}\right)$262.1080, found 262.1078. 


\section{2,3,4,9-Tetrahydro-7-methoxy-3-methyl-1H-carbazol-1-one ${ }^{33}(83)$.}

The same procedure as described for 5 was repeated except that a mixture of 5-methyl-3(4-methoxy-2-nitrophenyl)-2-cyclohexenone (125) (73.6 mg, $0.28 \mathrm{mmol}), \mathrm{Pd}(\mathrm{dba})_{2}(9.7 \mathrm{mg}, 0.02$ mmol), dppp (6.9 mg, $0.02 \mathrm{mmol}), 1,10$-phenanthroline monohydrate (6.7 mg, $0.04 \mathrm{mmol})$, and DMF (5 mL) gave $83(57.7 \mathrm{mg}, 0.25 \mathrm{mmol}, 89 \%)$ as a white powder.

\section{Methyl (+)-(S)-1-ethyl-2-oxo-3-cyclohexene-1-propanoate ${ }^{35}(109)$.}

To a solution of methyl (+)-(S)-1-ethyl-2-oxocyclohexane-1-propanoate ${ }^{35}$ (108) (3.25 g, $15.3 \mathrm{mmol})$ in DMF (23 mL) was added triethylamine $(11.3 \mathrm{~mL}, 81.1 \mathrm{mmol})$. Trimethylsilyl chloride $(5.93 \mathrm{~mL}, 46.7 \mathrm{mmol})$ was added slowly to the reaction mixture. The reaction mixture was heated at $100{ }^{\circ} \mathrm{C}$ for 3 days. The reaction mixture was allowed to cool to RT, and then was diluted with hexanes $(50 \mathrm{~mL})$ and poured into cold water $(50 \mathrm{~mL})$. The layers were separated, and the aqueous portion was extracted with hexanes $(3 \mathrm{X} 50 \mathrm{~mL})$. The organic phases were combined, dried $\left(\mathrm{MgSO}_{4}\right)$, and concentrated. To a portion of the crude silyl enol ether ${ }^{35}$ (1.94 $\mathrm{g}$, $6.82 \mathrm{mmol})$ in DMSO $(50 \mathrm{~mL})$ was added $\mathrm{Pd}(\mathrm{OAc})_{2}(159 \mathrm{mg}, 0.71 \mathrm{mmol})$. The flask containing the reaction mixture was flushed with oxygen, and was kept under oxygen ( 1 atm, balloon) while being heated at $40{ }^{\circ} \mathrm{C}$ for $72 \mathrm{hrs}$. Additional $\mathrm{Pd}(\mathrm{OAc})_{2}(95.6 \mathrm{mg}, 0.43 \mathrm{mmol})$ was added to the reaction mixture, and the reaction was heated at $60{ }^{\circ} \mathrm{C}$ for $24 \mathrm{hrs}$. The reaction mixture was cooled and diluted with ethyl acetate $(200 \mathrm{~mL})$. The reaction mixture was washed with water $(3$ X $50 \mathrm{~mL})$, dried $\left(\mathrm{MgSO}_{4}\right)$, and concentrated. The product was purified by flash chromatography (hexanes/EtOAc, 7:3) to give $\mathbf{1 0 9}(820 \mathrm{mg}, 3.90 \mathrm{mmol}, 57 \%)$ as a colorless oil. 


\section{Methyl (S)-1-ethyl-2-oxo-3-iodo-3-cyclohexenone-1-propanoate (127).}

The same procedure was repeated as described for $\mathbf{2 2}$ except that a solution of iodine (1.26 g, $4.96 \mathrm{mmol})$ in $\mathrm{CCl}_{4}(5 \mathrm{~mL})$ and pyridine $(5 \mathrm{~mL})$ was added to a solution of $\mathbf{1 0 9}(508 \mathrm{mg}$, $2.42 \mathrm{mmol})$ in $\mathrm{CCl}_{4}(5 \mathrm{~mL})$ and pyridine $(5 \mathrm{~mL})$. The product was purified via flash chromatography (hexanes/EtOAc, 8:2) to give 127 (698 mg, $2.08 \mathrm{mmol}, 86 \%$ ) as a light yellow oil: IR 3450, 2944, 1732, $1679 \mathrm{~cm}^{-1} ;{ }^{1} \mathrm{H}$ NMR $\delta 0.83(\mathrm{t}, J=7.5 \mathrm{~Hz}, 3 \mathrm{H}), 1.49-1.71(\mathrm{~m}, 2 \mathrm{H})$, 1.80-2.01 (m, 4H), 2.11-2.36 (m, 2H), 2.43-2.50 (m, 2H), $7.64(\mathrm{t}, J=4.1 \mathrm{~Hz}, 1 \mathrm{H}) ;{ }^{13} \mathrm{C} \mathrm{NMR} \delta$ $7.9(-), 26.8(+), 28.5(+), 28.5(+), 30.0(+), 47.7(+), 51.4(-), 103.4(+), 157.3(-), 173.5(+)$, 195.3 (+); HRMS (DEI) calcd for $\mathrm{C}_{12} \mathrm{H}_{17} \mathrm{IO}_{3}\left(\mathrm{MH}^{+}\right)$336.0222, found 336.0210.

\section{Methyl (S)-1-ethyl-2-oxo-3-(2-nitrophenyl)-3-cyclohexenone-1-propanoate (128).}

The same procedure as described for $\mathbf{3 2}$ was repeated except that a mixture of $\mathbf{1 2 7}$ (250 mg, 0.74 mmol), 1-(tri-n-butylstannyl)-2-nitrobenzene (25) (369 mg, 0.89 mmol), $\mathrm{PdCl}_{2}\left(\mathrm{PhCN}_{2}\right.$ (14.9 mg, $0.04 \mathrm{mmol}$ ), $\mathrm{Ph}_{3} \mathrm{As}$ (23.1 mg, $\left.0.08 \mathrm{mmol}\right), \mathrm{CuI}$ (14.5 mg, $0.08 \mathrm{mmol}$ ), and NMP (1.4 $\mathrm{mL})$ after $40 \mathrm{~h}$ gave 128 (196 mg, $0.59 \mathrm{mmol}, 80 \%)$ as a yellow oil: IR 3446, 2939, 1736, 1669, 1526, $1353 \mathrm{~cm}^{-1} ;{ }^{1} \mathrm{H}$ NMR $\delta 0.87(\mathrm{t}, J=7.5 \mathrm{~Hz}, 3 \mathrm{H}), 1.52-2.05(\mathrm{~m}, 6 \mathrm{H}), 2.28(\mathrm{t}, J=7.7 \mathrm{~Hz}, 2 \mathrm{H})$, $2.58(\mathrm{q}, J=4.6 \mathrm{~Hz}, 2 \mathrm{H}), 6.94(\mathrm{t}, J=4.2 \mathrm{~Hz}, 1 \mathrm{H}), 7.24(\mathrm{dd}, J=7.5$ and $1.4 \mathrm{~Hz}, 1 \mathrm{H}), 7.44(\mathrm{td}, J=$ 7.6 and $1.4 \mathrm{~Hz}, 1 \mathrm{H}), 7.57(\mathrm{td}, J=7.5$ and $1.4 \mathrm{~Hz}, 1 \mathrm{H}), 7.96(\mathrm{dd}, J=8.1$ and $1.2 \mathrm{~Hz}, 1 \mathrm{H}) ;{ }^{13} \mathrm{C}$ NMR $\delta 7.8(-), 22.6(+), 26.2(+), 28.4(+), 28.5(+), 30.0(+), 46.8(+), 51.4(-), 123.7(-), 128.5$ (-), $131.8(-), 132.1(+), 132.9(-), 138.0(+), 145.4(-), 148.7(+), 174.0(+), 199.3(+)$; HRMS (DEI) calcd for $\mathrm{C}_{12} \mathrm{H}_{17} \mathrm{IO}_{3}\left(\mathrm{MH}^{+}\right)$332.1498, found 332.1512. 
Methyl (-)-(S)-[3-ethyl-4-oxo-2,3,4,9-tetrahydro-1H-carbazol-3-yl]propanoate ${ }^{35}(112)$. $^{3}$

The same procedure as described for 5 was repeated except that a mixture of $\mathbf{1 2 8}$ (184 mg, $0.56 \mathrm{mmol}), \mathrm{Pd}(\mathrm{dba})_{2}(19.5 \mathrm{mg}, 0.03 \mathrm{mmol})$, dppp (14.0 mg, $\left.0.03 \mathrm{mmol}\right), 1,10-$ phenanthroline monohydrate $(13.5 \mathrm{mg}, 0.06 \mathrm{mmol})$, and DMF (5 mL) after chromatography and recrystallization (hexanes/EtOAc, 2:1) gave 112 (126 $\mathrm{mg}, 0.42 \mathrm{mmol}, 76 \%$ ) as a white crystalline solid.

\section{1,2,3,4-Tetrahydrocarbazole ${ }^{49 a}(129)$.}

Hydrogen gas was bubbled through a mixture of 2-(2-nitrophenyl)-2-cyclohexen-1-one (32) $(54.3 \mathrm{mg}, 0.25 \mathrm{mmol})$ and $10 \% \mathrm{Pd} / \mathrm{C}(50.7 \mathrm{mg})$ in $\mathrm{MeOH}(10 \mathrm{~mL})$ for $5 \mathrm{~min}$. The reaction mixture was stirred under $\mathrm{H}_{2}$ (1 atm, balloon) for $2 \mathrm{~h}$. The reaction mixture was filtered through Celite and concentrated. The crude product was purified by flash chromatography (hexanes/EtOAc, 8:2) to yield 129 (41.1 $\mathrm{mg}, 0.24 \mathrm{mmol}, 95 \%)$ as a white solid.

Alternate procedure A for 129 and 5. The same procedure as described above was repeated except that a mixture of $70(52.9 \mathrm{mg}, 0.23 \mathrm{mmol})$ and $10 \% \mathrm{Pd} / \mathrm{C}(51.6 \mathrm{mg})$ in $\mathrm{MeOH}$ (10 mL) gave 129 (8.5 mg, $0.049 \mathrm{mmol}, 22 \%)$ and 5 (18.9 mg, $0.10 \mathrm{mmol}, 45 \%)$.

Alternate procedure B for 129. The same procedure as described above was repeated except that a mixture of $5(18.5 \mathrm{mg}, 0.10 \mathrm{mmol})$ and $10 \% \mathrm{Pd} / \mathrm{C}(19.0 \mathrm{mg})$ in $\mathrm{MeOH}(5 \mathrm{~mL})$ gave 129 (6.0 mg, $0.035 \mathrm{mmol}, 35 \%)$ and recovered 5 (7.3 $\mathrm{mg}, 0.039 \mathrm{mmol}, 39 \%)$ after 3 days.

\section{[(4-Methyl-1-cyclohexen-1-yl)oxy]trimethylsilane (99a $^{\text {(139). }}$}

Butyllithium $(20.0 \mathrm{~mL}$ of a $2.5 \mathrm{M}$ solution in hexanes, $50.0 \mathrm{mmol})$ was added dropwise to a solution of diisopropylamine $(8.15 \mathrm{~mL}, 58.2 \mathrm{mmol})$ in THF $(160 \mathrm{~mL})$ cooled to $-78{ }^{\circ} \mathrm{C}$ 
under an argon atmosphere. The reaction mixture was stirred $10 \mathrm{~min}$ and a solution of 4methylcyclohexanone $(5.01 \mathrm{~g}, 44.6 \mathrm{mmol})$ in THF $(40 \mathrm{~mL})$ was added slowly to the reaction mixture. The reaction mixture was stirred for $30 \mathrm{~min}$, and then TMSCl $(6.80 \mathrm{~mL}, 53.6 \mathrm{mmol})$ and $\mathrm{Et}_{3} \mathrm{~N}(12.5 \mathrm{~mL}, 89.7 \mathrm{mmol})$ were added slowly. The reaction mixture was allowed to warm to room temperature over $1 \mathrm{~h}$. The reaction mixture was diluted with diethyl ether (400 mL), washed with water $(3 \times 100 \mathrm{~mL})$, dried $\left(\mathrm{MgSO}_{4}\right)$, and concentrated. The crude product was purified by flash chromatography (hexanes/EtOAc, 9:1) to give 139 (8.23 g, $44.6 \mathrm{mmol}, 100 \%)$ as a clear, colorless oil.

\section{4-Methyl-2-cyclohexen-1-one ${ }^{19}(140)$.}

To a solution of $139(3.14,17.0 \mathrm{mmol})$ in DMSO $(100 \mathrm{~mL})$ was added $\mathrm{Pd}(\mathrm{OAc})_{2}(366$ $\mathrm{mg}, 1.63 \mathrm{mmol}$ ). The reaction flask was flushed with $\mathrm{O}_{2}$ for $5 \mathrm{~min}$. The reaction mixture was stirred at $40{ }^{\circ} \mathrm{C}$ under $\mathrm{O}_{2}$ ( 1 atm, balloon) for $24 \mathrm{~h}$. The reaction mixture was allowed to cool, and then was diluted with $400 \mathrm{~mL}$ of EtOAc and washed with water $(3 \times 100 \mathrm{~mL})$. The organic phase was dried $\left(\mathrm{MgSO}_{4}\right)$ and concentrated. The crude product was purified by flash chromatography (hexanes:EtOAc, 9:1) to give 140 (676 g, $6.14 \mathrm{mmol}, 36 \%)$ as a clear, colorless oil.

\section{2-Iodo-4-methyl-2-cyclohexen-1-one (141).}

The same procedure was repeated as described for $\mathbf{2 2}$ except that a solution of iodine (2.97 $\mathrm{g}, 11.7 \mathrm{mmol})$ in $\mathrm{CCl}_{4}(10 \mathrm{~mL})$ and pyridine $(10 \mathrm{~mL})$ was added dropwise to a solution of $140(628 \mathrm{mg}, 5.70 \mathrm{mmol})$ in $\mathrm{CCl}_{4}(10 \mathrm{~mL})$ and pyridine $(10 \mathrm{~mL})$ to yield $141(873 \mathrm{mg}, 3.70$

mmol, 65\%) as a yellow oil: IR 2958, 2870, 1686, 1585, $1454 \mathrm{~cm}^{-1} ;{ }^{1} \mathrm{H}$ NMR $\delta 1.19(\mathrm{~d}, J=7.2$ 
$\mathrm{Hz}, 3 \mathrm{H}), 1.68-1.83(\mathrm{~m}, 1 \mathrm{H}), 2.11-2.23(\mathrm{~m}, 1 \mathrm{H}), 2.48-2.82(\mathrm{~m}, 3 \mathrm{H}), 7.61(\mathrm{~d}, J=2.9 \mathrm{~Hz}, 1 \mathrm{H}) ;{ }^{13} \mathrm{C}$ NMR $\delta 19.7(-), 30.6(+), 35.6(+), 35.7(-), 103.0(+), 164.7(-), 192.0(+)$.

\section{4-Methyl-2-(2-nitrophenyl)-2-cyclohexen-1-one (142).}

The same procedure as described for $\mathbf{3 2}$ was repeated except that a mixture of 2-iodo-4methyl-2-cyclohexen-1-one (141) (405 g, 1.72 mmol), 1-(tri-n-butylstannyl)-2-nitrobenzene (25) (854 mg, $2.07 \mathrm{mmol}), \mathrm{PdCl}_{2}(\mathrm{PhCN})_{2}(32.9 \mathrm{mg}, 0.09 \mathrm{mmol}), \mathrm{Ph}_{3} \mathrm{As}$ (52.6 mg, $\left.0.17 \mathrm{mmol}\right), \mathrm{CuI}$ (32.7 $\mathrm{mg}, 0.17 \mathrm{mmol})$, and NMP (4 mL) after 2 days gave $142(318 \mathrm{mg}, 1.38 \mathrm{mmol}, 80 \%)$ as a light yellow oil: IR 2960, 2871, 1682, 1525, $1352 \mathrm{~cm}^{-1} ;{ }^{1} \mathrm{H}$ NMR $\delta 1.26(\mathrm{~d}, J=7.1 \mathrm{~Hz}, 3 \mathrm{H})$, 1.74-1.91 (m, 1H), $2.14(\mathrm{~m}, 1 \mathrm{H}), 2.46-2.84(\mathrm{~m}, 3 \mathrm{H}), 6.81(\mathrm{~m}, 1 \mathrm{H}), 7.25(\mathrm{~d}, J=5.9 \mathrm{~Hz}, 1 \mathrm{H}), 7.47$ $(\mathrm{t}, J=6.3 \mathrm{~Hz}, 1 \mathrm{H}), 7.60(\mathrm{t}, J=7.9 \mathrm{~Hz}, 1 \mathrm{H}), 8.02(\mathrm{~d}, J=8.1 \mathrm{~Hz}, 1 \mathrm{H}) ;{ }^{13} \mathrm{C} \mathrm{NMR} \delta 20.2(-), 30.5$ (+), $31.6(-), 37.0(+), 124.1(-), 128.7(-), 131.6(-), 131.9(+), 133.2(-), 138.1(+), 148.5(+)$, $152.1(-), 196.4(+)$.

Impurity: 1-Nitro-2-(2-nitrophenyl)benzene (43). Partial ${ }^{1} \mathrm{H}$ NMR $\delta 7.79$ (t, $J=7.9$ Hz), 8.22 (d, $J=8.1 \mathrm{~Hz})$. Partial ${ }^{13} \mathrm{C}$ NMR $\delta 124.6(-), 129.0$ (-), 130.8 (-), 133.4 (-), 134.0.

\section{3-Methyl-2-(2-nitrophenyl)-2-cyclohexen-1-one (144).}

The same procedure as described for $\mathbf{3 2}$ was repeated except that a mixture of 2-iodo-3methyl-2-cyclohexen-1-one ${ }^{18}$ (143) (404 mg, 1.71 mmol), 1-(tri- $n$-butylstannyl)-2-nitrobenzene (25) (850 mg, $2.06 \mathrm{mmol}), \mathrm{PdCl}_{2}(\mathrm{PhCN})_{2}(32.9 \mathrm{mg}, 0.09 \mathrm{mmol}), \mathrm{Ph}_{3} \mathrm{As}(52.4 \mathrm{mg}, 0.17 \mathrm{mmol})$, CuI (32.8 mg, $0.17 \mathrm{mmol}$ ), and NMP (4 mL) gave $144(309 \mathrm{mg}, 1.33 \mathrm{mmol}, 78 \%)$ as a light yellow solid: $\mathrm{mp} 75-77{ }^{\circ} \mathrm{C}$; IR 2943, 2873, $1663,1622,1522,1356 \mathrm{~cm}^{-1} ;{ }^{1} \mathrm{H}$ NMR $\delta 1.78(\mathrm{~s}$, $3 \mathrm{H}), 1.99-2.22(\mathrm{~m}, 2 \mathrm{H}), 2.42-2.64(\mathrm{~m}, 4 \mathrm{H}), 7.16(\mathrm{dd}, J=7.5$ and $1.6 \mathrm{~Hz}, 1 \mathrm{H}), 7.47(\mathrm{td}, J=7.7$ 
and $1.6 \mathrm{~Hz}, 1 \mathrm{H}), 7.60(\mathrm{td}, J=7.5$ and $1.4 \mathrm{~Hz}, 1 \mathrm{H}), 8.08(\mathrm{dd}, J=8.1$ and $1.4 \mathrm{~Hz}, 1 \mathrm{H}) ;{ }^{13} \mathrm{C}$ NMR $\delta$ $21.8(+), 22.4(-), 32.3(+), 37.5(+), 124.4(-), 128.4(-), 131.7(+), 132.5(-), 133.0(-), 135.1(+)$, $148.8(+), 156.5(+), 196.6(+)$.

\section{1-Methyl-1,2,3,4-tetrahydrocarbazole ${ }^{67}(131)$.}

The same procedure as described for $\mathbf{1 2 9}$ was repeated except that a mixture of 6-methyl2-(2-nitrophenyl)-2-cyclohexen-1-one (115) (37.0 mg, $0.16 \mathrm{mmol}), 10 \% \mathrm{Pd} / \mathrm{C}(37.4 \mathrm{mg})$, and $\mathrm{MeOH}(10 \mathrm{~mL})$ after $2 \mathrm{~h}$ and chromatography (hexanes/EtOAc, 95:5) gave 131 (27.2 mg, 0.15 mmol, $91 \%)$ as a white solid.

\section{4-Methyl-1,2,3,4-tetrahydrocarbazole ${ }^{68}(134)$.}

The same procedure as described for $\mathbf{1 2 9}$ was repeated except that a mixture of 3-methyl2-(2-nitrophenyl)-2-cyclohexen-1-one (144) (155 mg, $0.67 \mathrm{mmol}), 10 \% \mathrm{Pd} / \mathrm{C}(151 \mathrm{mg})$, and $\mathrm{MeOH}(10 \mathrm{~mL})$ after $30 \mathrm{~min}$ and chromatography (hexanes/EtOAc/Et $3 \mathrm{~N}, 98: 2: 1 \mathrm{~mL}$ per $500 \mathrm{~mL}$ of solvent) gave $\mathbf{1 3 4}$ (97.6 $\mathrm{mg}, 0.52 \mathrm{mmol}, 78 \%)$ as a white solid.

\section{2-Methyl-1,2,3,4-tetrahydrocarbazole ${ }^{51}(135)$.}

The same procedure as described for $\mathbf{1 2 9}$ was repeated except that a mixture of 5-methyl2-(2-nitrophenyl)-2-cyclohexen-1-one (33) (100 mg, $0.43 \mathrm{mmol}), 10 \% \mathrm{Pd} / \mathrm{C}$ ( $100 \mathrm{mg}$ ), and $\mathrm{MeOH}(10 \mathrm{~mL})$ after $2 \mathrm{~h}$ and chromatography (hexanes/EtOAc/Et $3 \mathrm{~N}, 98: 2: 1 \mathrm{~mL} / 500 \mathrm{~mL}$ of solvent) gave 135 (73.6 $\mathrm{mg}, 0.40 \mathrm{mmol}, 92 \%)$ as a white solid. 
3-Methyl-1,2,3,4-tetrahydrocarbazole ${ }^{50 a}(145)$.

The same procedure as described for $\mathbf{1 2 9}$ was repeated except that a mixture of 4-methyl2-(2-nitrophenyl)-2-cyclohexen-1-one (142) (150 mg, $0.65 \mathrm{mmol}), 10 \% \mathrm{Pd} / \mathrm{C}$ (175 mg), and $\mathrm{MeOH}(10 \mathrm{~mL})$ after $30 \mathrm{~min}$ and chromatography (hexanes/EtOAc/Et $3 \mathrm{~N}, 98: 2: 1 \mathrm{~mL} / 500 \mathrm{~mL}$ of solvent) gave 145 (107 mg, $0.58 \mathrm{mmol}, 89 \%)$ as a white solid.

\section{1,2,3,3a,4,8b-Hexahydrocyclopent $[b]$ indole $^{69}(146)$.}

The same procedure as described for $\mathbf{1 2 9}$ was repeated except that a mixture of 2-(2nitrophenyl)-2-cyclopenten-1-one (34) (117 mg, $0.58 \mathrm{mmol}), 10 \% \mathrm{Pd} / \mathrm{C}$ (115 mg), and $\mathrm{MeOH}$ $(10 \mathrm{~mL})$ after $20 \mathrm{~min}$ without purification gave $146(76.1 \mathrm{mg}, 0.48 \mathrm{mmol}, 83 \%)$ as a white solid.

\section{$5,6,7,8,9,10-H e x a h y d r o c y c l o h e p t[b]$ indole $^{68}(147)$.}

The same procedure as described for 129 was repeated except that a mixture of 2-(2nitrophenyl)-2-cyclohepten-1-one (35) (65.8 mg, $0.28 \mathrm{mmol}), 10 \% \mathrm{Pd} / \mathrm{C}(66.0 \mathrm{mg})$, and $\mathrm{MeOH}$ $(10 \mathrm{~mL})$ after $2.5 \mathrm{~h}$ and chromatography (hexanes/EtOAc, 95:5) gave 147 (37.8 mg, $0.20 \mathrm{mmol}$, $72 \%)$ as a white solid.

\section{8-Methyl-1,2,3,4-tetrahydrocarbazole ${ }^{70}$ (148) and 8-Methyl-1,2,3,4,4a,9a- hexahydrocarbazol-1-one (149).}

The same procedure as described for 129 was repeated except that a mixture of 2-(3methyl-2-nitrophenyl)-2-cyclohexen-1-one (39) (90.7 mg, $0.39 \mathrm{mmol}), 10 \% \mathrm{Pd} / \mathrm{C}$ (90.5 mg), and $\mathrm{MeOH}(10 \mathrm{~mL})$ after $20 \mathrm{~min}$ and chromatography (hexanes/EtOAc/Et $3 \mathrm{~N}, 98: 2: 1 \mathrm{~mL}$ per $500 \mathrm{~mL}$ of solvent) gave a mixture of $148(12.7 \mathrm{mg}, 0.07 \mathrm{mmol}, 17 \%)$ as a white solid and 149 (31.9 $\mathrm{mg}$, 
$0.16 \mathrm{mmol}, 40 \%$ ) as a white solid: $\mathrm{mp} 102-104{ }^{\circ} \mathrm{C}$; IR $2934,1707,1516,1370 \mathrm{~cm}^{-1} ;{ }^{1} \mathrm{H}$ NMR $\delta$ 1.73-2.58 (m, 7H, $2.33(\mathrm{~s}, 3 \mathrm{H}), 3.64(\mathrm{dd}, J=12.4$ and $5.3 \mathrm{~Hz}, 1 \mathrm{H}), 7.16(\mathrm{~d}, J=7.9 \mathrm{~Hz}, 1 \mathrm{H}), 7.21$ $(\mathrm{d}, J=7.7 \mathrm{~Hz}, 1 \mathrm{H}), 7.39(\mathrm{t}, J=7.7 \mathrm{~Hz}, 1 \mathrm{H}) ;{ }^{13} \mathrm{C}$ NMR $\delta 17.7(-), 25.4(+), 27.5(+), 35.1(+)$, $42.1(+), 52.4(-), 127.4(-), 129.5(+), 129.9(-), 130.0(-), 130.8(+), 151.4(-), 207.7(+)$.

Alternate procedure for compound 149. 8-Methyl-1,2,3,4,4a,9a-hexahydrocarbazol-1one (149) was also prepared exclusively in the same manner as described above using a mixture of $39(141 \mathrm{mg}, 0.61 \mathrm{mmol}), 10 \% \mathrm{Pd} / \mathrm{C}(13.4 \mathrm{mg})$, and $\mathrm{MeOH}(10 \mathrm{~mL})$ after $1 \mathrm{~h} 20 \mathrm{~min}$ to give 149 (136 mg, $0.67 \mathrm{mmol}, 100 \%)$.

\section{5-Carbomethoxy-1,2,3,4-tetrahydrocarbazole (150) and 5-Carbomethoxy-1,2,3,4,4a,9a-} hexahydrocarbazol-1-one (151).

The same procedure as described for $\mathbf{1 2 9}$ was repeated except that a mixture of 2-(6carbomethoxy-2-nitrophenyl)-2-cyclohexen-1-one (40) (50.8 mg, $0.18 \mathrm{mmol}), 10 \% \mathrm{Pd} / \mathrm{C}$ (54.9 $\mathrm{mg}$ ), and $\mathrm{MeOH}(10 \mathrm{~mL})$ after $2 \mathrm{~h}$ and chromatography (hexanes/EtOAc, 95:5) gave a mixture of 150 (10.7 mg, $0.05 \mathrm{mmol}, 25 \%)$ and $\mathbf{1 5 1}(16.8 \mathrm{mg}, 0.07 \mathrm{mmol}, 37 \%)$ as white solids: $\mathbf{1 5 0}{ }^{1} \mathrm{H}$ NMR $\delta$ 1.77-1.97 (m, 4H), 2.73-2.82 (m, 2H), 2.85-2.93 (m, 2H), 3.94 (s, 3H), 7.11 (td, $J=7.7$ and $1.7 \mathrm{~Hz}, 1 \mathrm{H}), 7.43(\mathrm{dt}, J=8.1$ and $1.7 \mathrm{~Hz}, 1 \mathrm{H}), 7.64(\mathrm{dt}, J=7.4$ and $1.7 \mathrm{~Hz}, 1 \mathrm{H}), 7.93(\mathrm{~s}$, $1 \mathrm{H}) ; 151{ }^{1} \mathrm{H}$ NMR $\delta$ 1.58-1.77 (m, 4H), 1.89-2.06(m, 2H), $3.51(\mathrm{p}, J=6.2 \mathrm{~Hz}, 1 \mathrm{H}), 3.80-3.87$ (m, 2H), $3.88(\mathrm{~s}, 3 \mathrm{H}), 6.84(\mathrm{~d}, J=7.9 \mathrm{~Hz}, 1 \mathrm{H}), 7.07$ (t, $J=7.9 \mathrm{~Hz}, 1 \mathrm{H}), 7.36(\mathrm{~d}, J=7.9 \mathrm{~Hz}, 1 \mathrm{H})$. 
7-Methoxy-1,2,3,4-tetrahydrocarbazole $\mathrm{e}^{71}$ (152) and 7-Methoxy-1,2,3,4,4a,9ahexahydrocarbazol-1-one ${ }^{72}(153)$

The same procedure as described for $\mathbf{1 2 9}$ was repeated except that a mixture of 2-(4methoxy-2-nitrophenyl)-2-cyclohexenone (37) (105 mg, $0.42 \mathrm{mmol}), 10 \% \mathrm{Pd} / \mathrm{C}$ (104 mg), and $\mathrm{MeOH}(10 \mathrm{~mL})$ after $20 \mathrm{~min}$ and chromatography (hexanes/EtOAc/Et ${ }_{3} \mathrm{~N}, 95: 5: 1 \mathrm{~mL}$ per $500 \mathrm{~mL}$ of solvent) gave an inseparable mixture of $152(52.5 \mathrm{mg}, 0.26 \mathrm{mmol}, 62 \%)$ and 153 (7.9 mg, $0.04 \mathrm{mmol}, 9 \%$ ). Yields were estimated from the ${ }^{1} \mathrm{H}$ NMR spectrum. 


\section{References}

1. Moody, C. J. Synlett 1994, 681.

2. Kim, M. Y.; Lim, G. J.; Lim, J. I., Kim, D. S.; Kim, I. Y.; Yang, J. S. Heterocycles 1997, 45, 2041.

3. a) Ramesh, K.; Kapil, R. S. Indian J. Chem. 1986, 25b, 462. b) Ramesh, K.; Kapil, R. S. Chem. Ind. (London) 1986, 614.

4. Rodriguez, J.-G.; Temprano, F.; Esteban-Calderon, C.; Martinez-Ripoll, M. J. Chem. Soc. Perkin Trans. 1 1989, 2117.

5. Iida, H.; Yuasa, Y.; Kibayashi, C. J. Org. Chem. 1980, 45, 2938.

6. Ianelli, S.; Nardelli, M.; Belletti, D.; Caubere, C.; Caubere, P.; Jamart-Gregoire, B. Acta Cryst. 1994, C50, 1919.

7. Blache, Y.; Chavignon, O.; Sinibaldi-Troin, M.-E.;Voldoire, A.; Chavignon, O.; Teulade, J. C.; Chapat, J.-P.; Gramain, J. C. J. Org. Chem. 1997, 62, 8553.

8. Joseph, B.; Cornec, O.; Merour, J.-Y.; Solans,X.; Font, Barolia, M. J. Heterocyclic Chem. 1997, 34, 525.

9. Söderberg, B. C.; Shriver, J. A. J. Org. Chem. 1997, 62, 5838.

10. Söderberg, B. C.; Chisnell, A. C.; O’Neil, S. N.; Shriver, J. A. J. Org. Chem. 1999, 64, 9731.

11. Akazome, M.; Kondo, T.; Watanabe, Y. J. Org. Chem. 1994, 59, 3375.

12. Tollari, S.; Cenini, S.; Crotti, C.; Gianella, E. J. Mol. Catal. 1994, 87, 203.

13. Söderberg, B. C. G. Current Organic Chemistry 2000, 4, 727.

14. Johnson, C. R.; Adams, J. P.; Braun, M. P.; Senanayake, C. B. W. Tetrahedron Lett. 1992, 33, 919.

15. a) Farina, V.; Krishnan, B.; Marshall, D. R.; Roth, G. P. J. Org. Chem. 1993, $58,5434$.

b) Barbarella, G.; Zambianchi, M. Tetrahedron 1994, 50, 1249. c) Kikukawa, K.; Kono, K.; Wada, F.; Matsuda, T. J. Org. Chem. 1983, 48, 1333.

16. a) Echavarren, A. M.; Stille, J. K. J. Am. Chem. Soc. 1987, 109, 5478. b) Farina, V. Kapadia, S.; Krishnan, B.; Wang, C.; Liebeskind, L. S. J. Org. Chem. 1994, 59, 5905. c) 
Gomez-Bengoa, E.; Echavarren, A. M. J. Org. Chem. 1991, 56, 3497.

17. Kosugi, M.; Ohya, T.; Migita, T. Bull. Chem. Soc. 1983, 56, 3855.

18. Johnson, C. R.; Adams, J. P.; Braun, M. P.; Senanayake, C. B. W.; Wovkulich, P. M.; Uskokovich, M. R. Tetrahedron Lett. 1992, 33, 917.

19. Chong, B.-D.; Yong-Il, J.; Oh, S.-S.; Yang, J.-D.; Baik, W.; Koo, S. J. Org. Chem. 1997, $62,9323$.

20. Larock, R. C.; Hightower, T. R.; Kraus, G. A.; Hahn, P.; Zheng, D. Tetrahedron Lett. 1995, 36, 2423.

21. Collington, E. W.; Jones, G. J. Chem. Soc. (C) 1969, 2656.

22. Gallo, E.; Ragaini, S.; Cenini, S.; Demartin, F. J. Organomet. Chem. 1999, 586, 190.

23. Sole, D.; Bosch, J.; Bonjoch, J. Tetrahedron 1996, 52, 4013.

24. Harrington, P. J.; Hegedus, L. S. J. Org. Chem. 1984, 49, 2657

25. Ragaini, F.; Sportiello, P.; Cenini, S. J. Organomet. Chem. 1999, 577, 283.

26. Akazome, M.; Kondo, T.; Watanabe, Y. Chem. Lett. 1992, 769.

27. Crotti, C.; Cenini, S.; Bassoli, A.; Rindone, B.; Demartin, F. J. Mol. Catal. 1991, 70, 175.

28. Bringmann, G.; Tasler, S.; Endress, H.; Peters, K.; Peters, E. Synthesis 1998, 1501.

29. Furukawa, H.; Wu, T.; Ohta, T.; Kuoh, C. Chem. Pharm. Bull. 1985, 33, 4132.

30. Murakami, Y.; Yokoo, H.; Watanabe, T. Heterocycles 1998, 49, 127.

31. Bringmann, G.; Ledermann, A.; Francois, G. Heterocycles 1995, 40, 293.

32. Chakraborty, D. P.; Chowdhury, B. K. J. Org. Chem. 1968, 33, 1265.

33. Saha, C.; Chowdhury, B. K. Phytochemistry 1998, 48, 363.

34. http://www.kerala.org/cuisine/contribs/curryleaf.html

35. Desmaele, D.; d'Angelo, J. J. Org. Chem. 1994, 59, 2292.

36. Murakami, Y.; Yokoo, H.; Watanabe, T. Heterocycles 1998, 49, 127. 
37. Martin, T.; Moody, C. J. J. Chem. Soc. Perkin Trans. 1 1988, 235.

38. Miki, Y.; Hachiken, H. Synlett 1993, 333.

39. Hagiwara, H.; Choshi, T.; Fujimoto, J.; Sugino, E.; Hibino, S. Chem. Pharm. Bull. 1998, $46,1948$.

40. Murphy, W. S.; Bertrand, M. J. Chem. Soc., Perkin Trans. 1 1998, 4115.

41. $\AA$ Åkermark, B.; Oslob, J. D.; Heuschert, U. Tetrahedron Lett. 1995, 36, 1325.

42. Knölker, H.-J.; Bauermeister, M. J. Chem. Soc., Chem. Commun. 1990, 664.

43. Lin, G.; Zhang, A. Tetrahedron Lett. 1999, 40, 341.

44. Suzuki, H.; Thiruvikraman, S. V.; Osuka, A. Synthesis 1984, 616.

45. Matsuo, K.; Ishida, S. Chem. Pharm. Bull. 1994, 42, 1325.

46. Piers, E.; Nagakura, I. Synth. Commun. 1975, 5, 193.

47. Ramesh, K.; Kapil, R. S. J. Nat. Prod. 1987, 50, 932.

48. $\quad$ Lin, G.; Zhang, A. Tetrahedron Lett. 1999, 40, 341.

49. a) Iwama, T.; Birman, V. B.; Kozmin, S. A.; Rawal, V. H. Org. Lett. 1999, 1, 673. b) Moody, C. J.; Rahimtoola, K. F. J. Chem. Soc., Perkin Trans. 1 1990, 673. c) Ho, T. L.; Wong, C. M. Synthesis 1974, 45.

50. a) Stoermer, D.; Heathcock, C. H. J. Org. Chem. 1993, 58, 564. b) Miller, F. M.; Schinske, W. N. J. Org. Chem. 1978, 43, 3384.

51. Chen, C.-i.; Lieberman, D. R.; Larsen, R. D.; Verhoeven, T. R.; Reider, P. J. J. Org. Chem. 1997, 62, 2676.

52. Tanaka, H.; Murakami, Y.; Torii, S. Bull. Chem. Soc. Jpn. 1989, 62, 4061.

53. Bovonsombat, P.; Angara, G. J.; NcNelis, E. Tetrahedron Lett. 1994, 35, 6787.

54. Adam, W.; Klug, P. Synthesis 1994, 6, 557.

55. Anderson, J. C.; Pearson, D. J. J. Chem. Soc., Perkin Trans. 1 1998, 2023. 
56. Olah, George A.; Lin, Henry C. J. Am. Chem. Soc. 1974, 96, 2892.

57. Seko, S.; Miyake, K.; Kawamura, N. J. Chem. Soc., Perkin Trans. 1, 1999, 11, 1437.

58. Hodgeson, H. H.; Moore, F. H. J. Chem. Soc. 1926, 155.

59. Hellberg, L. H.; Juarez, A. Tetrahedron Lett. 1974, 40, 3553.

60. Nicolaou, K. C.; Zhong, Y.-L.; Baran, P. S. J. Am. Chem. Soc. 2000, 122, 7596.

61. Bobbitt, J. M.; Guttermuth, M. C. F.; Ma, Z.; Tang, J. Heterocycles 1990, 30(2, Spec. Issue), 1131.

62. Anderson, B. A.; Bach, N. J.; Bastian, J. A.; Harn, N. K.; Harper, R. W.; Hite, G. A.; Kinnick, M. D.; Lin, H.; Loncharich, R. J.; McGill, J. M.; Mihelich, E. D.; Morin, J. M.; Phillips, M. L.; Richett, M. E.; Sall, D. J.; Sawyer, J. S.; Schevitz, R. W.; Vasileff, R. T. (Eli Lilly and Co., USA). Eur. Pat Appl. 0950657A2, 1999.

63. Coates, I. H.; Bell, J. A.; Humber, D. C.; Ewan, G. B. Eur. Pat. Appl. 0219193, 1987.

64. Hagiwara, H.; Choshi, T.; Fujimoto, H.; Sugino, E.; Hibino, S. Chem Pharm. Bull. 1998, $46,1948$.

65. Shinada, T.; Miyachi, M.; Itagaki, Y.; Naoki, H.; Yoshihara, K.; Nakajima, T. Tetrahedron Lett. 1996, 37, 7099.

66. Sakamoto, T.; Kondo, Y.; Uchiyama, M.; Yamanaka, H. J. Chem. Soc., Perkin Trans. 1 1993, 17, 1941.

67. Naruse, Y.; Ito, Y.; Inagaki, S. J. Org. Chem. 1991, 56, 2256.

68. Tsujimoto, K.; Ohashi, M.; Yonezawa, T. Bull. Chem. Soc. Jpn. 1973, 46, 3605.

69. Gataullin, R. R.; Kazhanova, T. V.; Ill'yasova, L. T.; Fatykhov, A. A.; Spirikhin, L. V.; Abdrakhmanov, I. B. Russ. Chem. Bull. 1999, 48, 967.

70. Tsugi, Y.; Huh, K. T.; Watanabe, Y. J. Org. Chem. 1987, 52, 1673.

71. Monti, S. A.; Johnson, W. O. Tetrahedron 1970, 26, 3685.

72. Achenbach, H.; Raffelsberger, B.; Addae-Mensah, I. Liebigs Ann. Chem. 1982, 5, 830. 


\section{Tricia Leigh Scott}

Office Address

Department of Chemistry

West Virginia University

Morgantown, WV 26506-6045

Phone: 304-293-3060 ext. 4242

fax: 304-293-4904

e-mail: tscott2@aol.com

\section{Home Address}

115 East High Street, Apt. 4

Kingwood, WV 26537

Phone: 304-329-3213

\section{Education}

Ph.D., Organic Chemistry, West Virginia University, Morgantown, West Virginia, 2001. Dissertation: "Palladium-Catalyzed Synthesis of Carbazole Derivatives and Formal Total Syntheses of Several Naturally Occurring Carbazole Alkaloids."

B.S., Summa Cum Laude, Chemistry, Fairmont State College, Fairmont, West Virginia, 1996.

\section{Research Experience}

West Virginia University, 1998-2001

Research Director: Professor Björn C. Söderberg

The preparation of carbazole derivatives via two palladium-catalyzed reactions, a Stille coupling followed by a reductive $N$-heteroannulation was investigated. This method was applied to the syntheses of several naturally occurring carbazole alkaloids. The reduction of 2-(2-nitrophenyl)-2-cyclohexenones, followed by cyclization, leading to 1,2,3,4tetrahydrocarbazoles is currently being investigated.

West Virginia University, 1997-1998

Research Director: Professor Debra L. Mohler

The development of cyclopentadienyl metal complexes as new agents for the modification of oligonucleotides was investigated. The mechanism of DNA modification, the attachment of DNA recognition elements to the complexes, and the use of chemiluminescent detection methods in DNA affinity cleavage and sequencing experiments were also studied. 
Fairmont State College, Spring 1994

Research Advisor: Professor Albert Magro

An enzyme-linked immunochemical assay to measure the titer of antibodies directed at specific antigens was developed and characterized.

\section{Teaching Experience}

\section{West Virginia University}

Teaching Assistant for undergraduate General Chemistry and Organic Chemistry, Fall 1996, Summer 1998, Fall 1998.

Designed a project appropriate for undergraduate research and supervised the research activities of undergraduate students, Summer 1997, Spring 1998, Spring 2001.

\section{Fairmont State College}

Teaching Assistant for undergraduate General Chemistry, Fall 1995 and Spring 1996.

Chemistry Tutor, Fall 1993-Spring 1996.

\section{Additional Experience}

Departmental Safety Committee member, West Virginia University, January 1998 - June 2001.

President, Fairmont State College American Chemical Society Student Affiliates, 1995-1996 academic year.

\section{Honors and Awards}

West Virginia University Safety Committee Achievement Award, 1999, 2000, and 2001. American Chemical Society Women Chemists Committee Travel Award, 2000.

Winifred Knutti Outstanding Female Graduate Student, 1998.

Phi Lambda Upsilon Chemistry Honorary Society Member, 1997-present.

Trotter Fellowship, 1996-2001.

Hodge Fellowship, 1996-2001.

Eberly College of Arts and Sciences Endowed Fellowship, 1996-2000. 
William C. Ruoff Memorial Fund Award, 1996.

Outstanding Senior Chemistry Award, 1996.

Eleanor M. Ford Outstanding Senior in Science and Mathematics Award, 1996.

Fairmont State College ACS Outstanding Junior in Chemistry Award, 1995.

Outstanding Freshman Chemistry Award, 1993.

\section{Publications}

Hurley, A. L.; Scott, T. L.; Flood, M. R.; Mohler, D. L. "Photoinduced DNA Cleavage by Cyclopentadienyl Metal Complexes Conjugated to DNA Binding Elements," Organic Letters, accepted July 2001.

Mohler, D. L.; Dain, D. R.; Kerekes, A. D.; Nadler, W. R.; Scott, T. L. "Organometallic Photonucleases: A Novel Class of DNA-Cleaving Agents," Bioorganic and Medicinal Chemistry Letters 1998, 8, 871.

Söderberg, B. C. G.; Scott, T. L. "Novel Palladium-Catalyzed Synthesis of Carbazolones," manuscript under preparation.

Söderberg, B. C. G.; Scott, T. L. "Palladium-Catalyzed Synthesis of Carbazolones and the Formal Total Syntheses of Several Carbazole Alkaloids," manuscript under preparation.

\section{Presentations}

Söderberg, B. C.; Scott, T. L. "Synthesis of Tetrahydrocarbazoles," presented at the 221st ACS National Meeting, San Diego, California, April 2001; ORGN-381.

Söderberg, B. C.; Scott, T. L. "Novel Palladium-Catalyzed Synthesis of Carbazolones and the Formal Total Syntheses of Several Naturally Occurring Carbazole Alkaloids," presented at the 220th ACS National Meeting, Washington, D. C., August 2000; ORGN459.

Söderberg, B. C.; Turner, M. R.; Scott, T. L. "Novel Synthesis of 3-Substituted Indoles and Carbazoles," presented at the 218th ACS National Meeting, New Orleans, August 22-26, 1999; ORGN-301.

Söderberg, B. C.; Turner, M. R.; Scott, T. L.; Arrington, A. K.; O’Neil, S. N.; Shriver, J.A.; Rector, S. R.; Criser, A. L.; Chisnell, A. C. "Palladium-Catalyzed Synthesis of Indoles and Carbazoles," presented at the 17th International Congress of Heterocyclic Chemistry, Vienna, Austria, August 1-6, 1999; Abstract 572. 
Mohler, D. L.; Scott, T. L.; Flood, M. R. "Cyclopentadienyl Metal Complexes As

Photonucleases: A Novel Class of DNA Cleaving Agents," presented at the West Virginia University ACS Meeting-In-Miniature, Morgantown, WV, April 18, 1998; paper O4.

Mohler, D. L.; Scott, T. L. "Cyclopentadienyl Metal Complexes As Photonucleases: A Novel Class of DNA Cleaving Agents," presented at the 215th ACS National Meeting, Dallas, March 29-April 2, 1998; ORGN-299.

Mohler, D. L.; Gannett, P.; Scott, T. L.; Flood, M. R. "Cyclopentadienyl Metal Complexes As Photonucleases: A Novel Class of DNA Cleaving Agents," presented at the ACS Southeastern Regional Meeting, Roanoke, VA, October 20-22, 1997; paper 350.

Scott, T. L.; Wolfe, K. L.; Magro, A. "Development of A Rapid and Sensitive Assay for Antigen Specific Immunoglobulins," presented at the West Virginia Academy of Science, Fairmont, WV, April 1994.

\section{References}

Professor Björn C. Söderberg

Department of Chemistry

West Virginia University

P. O. Box 6045

Morgantown, WV 26506-6045

Phone: 304-293-3435 ext. 4434

e-mail: bsoderbe@wvu.edu

Professor Kung K. Wang

Department of Chemistry

West Virginia University

P. O. Box 6045

Morgantown, WV 26506-6045

Phone: 304-293-3435 ext. 4441

e-mail: kwang@wvu.edu

Professor Paul W. Jagodzinski, Chair

Department of Chemistry

West Virginia University

P. O. Box 6045

Morgantown, WV 26506-6045

Phone: 304-293-3435

e-mail: pwjag@wvu.edu 


\section{Professor Albert Magro}

School of Math \& Science

Fairmont State College

1201 Locust Ave.

Fairmont, WV 26554

Phone: 304-367-4877

e-mail: amagro@mail.fscwv.edu

Professor Matthew Scanlon

School of Math \& Science

Fairmont State College

1201 Locust Ave.

Fairmont, WV 26554

Phone: 304-367-4504

e-mail: mscanlon@mail.fscwv.edu 